\title{
GLODEP2: A Computer Model for Estimating Gamma Dose due to Worldwide Fallout of Radioactive Debris
}

\author{
Leslie L. Edwards \\ Ted F. Harvey \\ Kendail R. Peterson
}

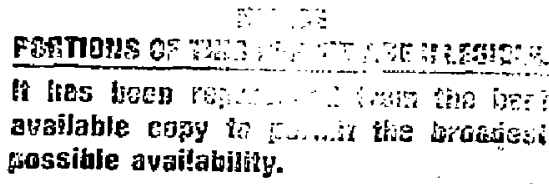

March 1984

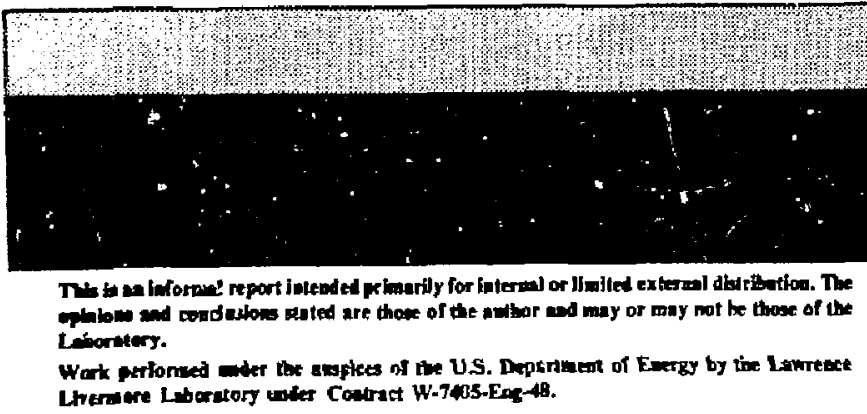

4

\section{DISCLAFMER}

This crport was picparad as an account of work epencored by an agency of the United Slateg Government Neilber the Uaited States Government not any agency thereoe, ror any of their emplojoes, exales eny warranty, express or inplied, or essunes any legal liability or responit iflity for the eccuracy, completeness, or usefulness of any information, apparatus, product of proceses dieckosed, of tepresents that its we wauld not infringe privalely owned rights. Refereace hersit to any opecific coraraerial product, process, or service by trade name, trademart, manfacturef, of otherwise does nol nocessarily constitute or imply its endorsement, recom-

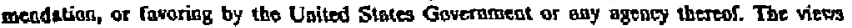
end opinints of authors expressed hercin do nal necessarily state or fuflect those of the Uailed States Government or any agency thereof.

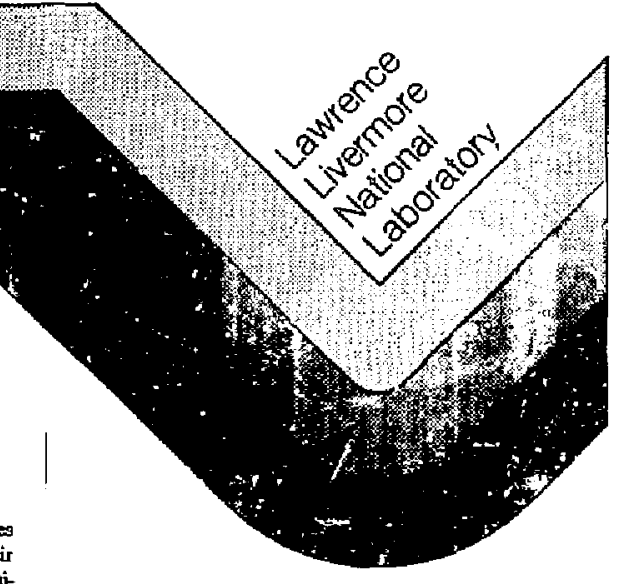


UCID-20033

\title{
GLODEP2 : A Computer Model For Estimating Gamma Dose due to Worldwide Fallout of Radionetive Debris
}

\author{
Leslie L. Edwards \\ Ted F. Harvey \\ Kendall R. Peterson \\ Mareh 1984
}

\begin{abstract}
The GLODEP2 computer code provides estimates of the surface deposition of "worldwide" radioactivity and the gamma-ray dose to man from intermediate and long-term fallout. The code is based of empirical models derived primarily from injection-deposition experience gained from the U.S. and U.S.S.R. nuelear tests in 1958.
\end{abstract}

Under the assumption that a nuclear power facility is destroyed and that its debris behaves in the same manner as the radioactive cloud produced by the nuclear weapon that attacked the facility, predictions are made for the gamma dose from this souree of radionetivity.

Empiriesl gamma dose models that account for meteorology, weathering and terrain roughness shielding at specific locations are included.

As a comparison study the gamma dose due to the atmospheric nuclear tests from the period of 1951-1962 has been corputed. The computed and measured values from Grove, U.K. and Chiba, Japan agree to within a few percent.

The global deposition of radioactivity and resultant gamma dose from a hypothetical strategic nuclear exchange between the U.S. and the U.S.S.R. is reported. Of the assumed $5300 \mathrm{Mton}$ in the exchange, 2031 Mton of radioactive debris is injected in the atmosphere. The righest estimated average whole body total integrated dose over 50 years (assuming no reduction by sheltering or weathering) is $23 \mathrm{rem}$ in the 30-50 degree latitude band. If the attack included a $100 \mathrm{GW}(e)$ nuclear power industry as targets in the U.S., thus dose is inereased to 84.6 rem. "Hotspots" due to rainfall could increase these values by factors of 10-50, 
The local unsheltered dose including rainfald, weathering and terrain roughness for grassy fielis near non-combatant cities has been estimated for the scenario including the nuclear industry. Results indicate that London, U.K. would receive gbout 18 rem, Montreal, Canaca and Lisbon, Portugal about 22 rem, Tokyo, Japan about 27 rem, and Sydney, Australia about 0.6 rem.

If a large nuclear exchange were to occur and if, in fact, the exchange caused a "nuclear winter" it is probable that the current empirical general circulation and meteorological models would no longer be valid. All of the above results could be changed significantly if such effects greatly changed the fallout and deposition patterns.

\section{INTRODUCTION}

All nuclear detonations at or above the surface produce at mospheric radioactive debris. Most of this debris is subsequently deposited on the earth's surface from minutes to years after the event. The potential hazand of radioactive fallout was recognized by scientists even before the Trinity test at Almagordo, New Mexico on July 16, 1945 [1] As is well known, the peacetime test ing of nuclear weapons in the atmosphere is capable of producing global contamination and was the subject of intense worlciwide coneern between 1954 and 1963 when the limited test ban treaty was signed.

Over the past several decades there has been continuing research and debate on the effects of nuclear war. Recently an entire issue of AMBIO [2] was devoted to the topic of the aftermath of nuclear war.

In August 1975 the National Academy of Sciences (NAS) publisher a study of Iong-term effects of multiple nuclear weapons detonations [3] In that report it was noted that

"In the event of a nuclear exchunge, nuelear power related installations such as nuclear powar plants, nticlear fuel manufacturing and reproxessing plants, and nuclear waste storage facilities may pose sperial problems because of the radioactive materials that they contain." 
The NAS report does not examine these problems. However, C. V. Chester and $R$. 0 . Chester [4] published a study of local fallout from nuclear power facilities in 1976. The AMBIO [2] publication also addresses this problem.

The objective of this report is to document the development of a computer code, GLODEP 2, capable of estimating the potential hazard due to gamma-ray dose from radioactive worldwide fallout.

Local fallout oceurs mostly downwind of the detonation site on a time scale of hours to a day after the burst and will not be considered in this report.

Intermediete fallout occurs on a time scale of days to a month or two. The debris cloud encircles the globe, perhaps several times, as a diffusing cloud of deereasing radioactivity. This portion of the fallout is contained within the troposphere, the first $9-17 \mathrm{~km}$ of the atmosphere. A Gaussian diffusion deposition model is einployed to model this fallout.

Long-term fallout is defined as debris initially placed into the stratosphere, or higher, that deposits over the globe on a time scale of months to years af ter nuclear events. Ir: GLODEP2 this fallout is modeled in essentially the same manner as that reported by Peterson [5] in 1970.

Given the yield, fission fraction, height of burst, latitude and season of earch nuclear burst and the type of nuclear installation (if any) involved, the fractional injections into the atmosphere and surface deposition of radioactive debris is predieted. This debris is then converted to a gamma-ray dose to man.

Specific location dose calculations include weathering; penetration and runcrf as well as rainfall factors. The models are based on the empirical works of Gale, Humphreys and Fisher [6] and Lowder, Beck and Condon [7] 
The decay laws and "dose-area-integral" values for conversion to gamma-ray dose for nuclear power installations are taken from the work of Chester and Chester [4] The empirical data for the deposition madel used in the code are taken from Peterson [5] and are included in Appendix A.

The model deseriptions will be delineated in Section 2, the GLODEP2 code deseription is given in Section 3, sample calculations appear in Section 4, and finally discussion and conclusions are presented in Section 5. A code "Users Guiae" is included in Appendix B.

\section{EMPIRICAL AND MATHEMATICAL MODELS}

This section presents the models used in the GLODEP2 eomputer code. It is important to note that these models are based on measurements and that all "parameters" are empirical. The computer code as such was not developed using adjustable parameters to be "tuned" to the date.

\subsection{Injeetion Model}

Due to lack of knowledge of the detailed relationship between injections into various portions of the atmosphere and subsequent deposition, it is assumed that the atmosphere can be partitioned into compartments such that debjis injected into a particular compartment will behave the same irrespective of where in the compartment it is injected. The partitioning is shown in Figure 1. Two latitude bands nave been selected: $0-30$ degrees North, called equatorial; and 30-90 degrees North, called polar.

Using the same methodology as Peterson [5], the lower boundary of the stratospheric compartments is the tropopause, assumed as $17 \mathrm{~km}$ for equatorial regions and $9 \mathrm{~km}$ for polar regions. The top compartments extend upward to $300-500 \mathrm{~km}$ but a practical limit of $400 \mathrm{~km}$ is used in GLODEP2. Results from a 1962 nigh altitude burst (List et al. [8] indicate that most of the debris placed initially at of below these levels will not escape the earth's atmosphere and will eventuslly be deposited on the surface. 


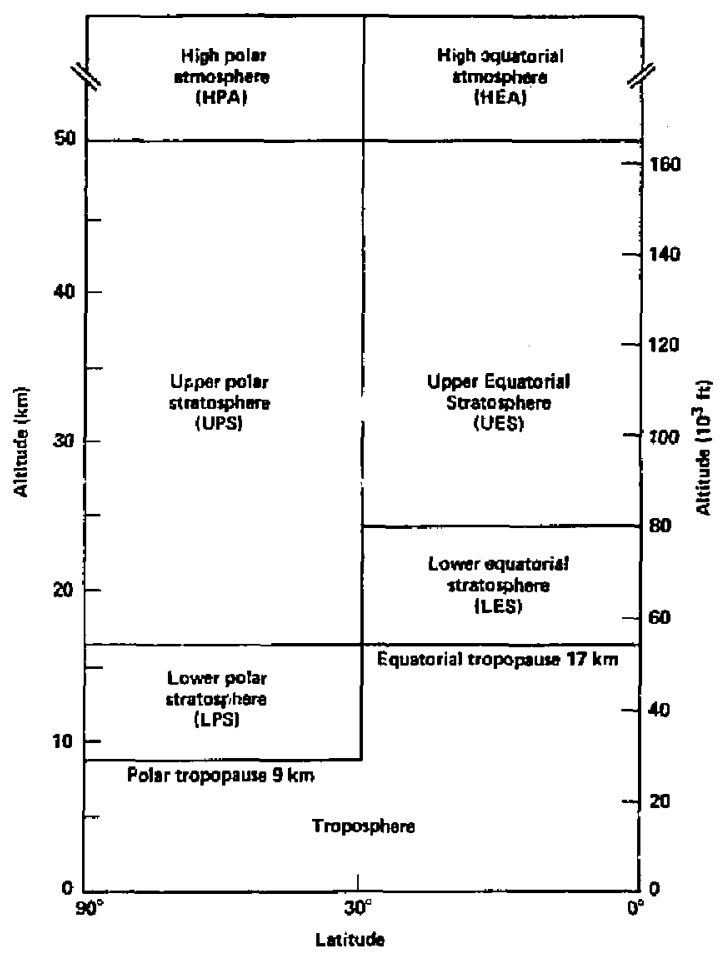

Figure 1. Atmospheric compartments for partitioning nuclear debris. The highest compartments extend to heights so that most of the injeeted debris will be eventually deposited on the surface (Peterson, 1970).

The tops and bases of the mushroom cap debris clouds are assumed to vary with total yield according to the curves in Figure 2. Peterson based this diagram on equatorial cloud measurements by Ferber [9] and the U.S. Weather Bureau [10] The polar top and base curves in this figure were estimated by comparisons of equatorial and polar atmospheric stabilities [5L Additional work by Seitz et al. [11] in 1968 indicate lower cloud values for yields above 3 Mton. In 1979 Telegadas [12] reported studies of the Chinese (PRC) atmospheric tests at 40 degrees North. His curves are based on aireraft samples taker "weeks or month" after each nuclear test, all in the 0.02-4 Mton range. Telegadas' eloud tops above 3 Mton appear to be similar to Peterson's polar tops. See, for example, Figure 3 taken from the 1979 work of Bauer [13] 


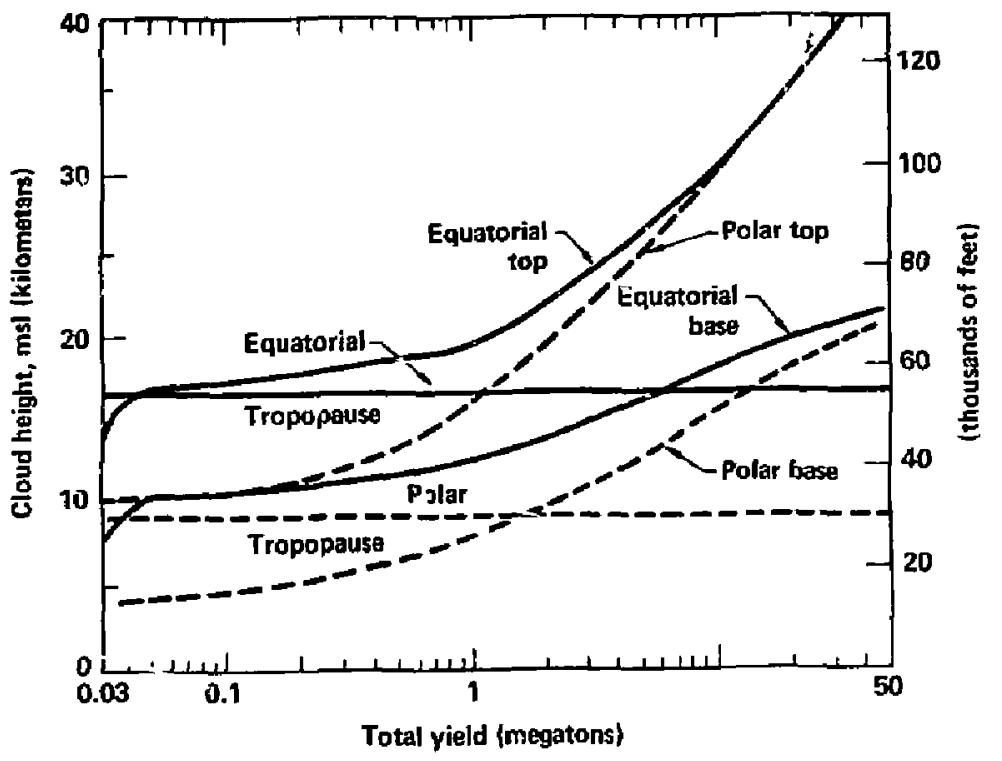

Figure 2 "Mushroom cap" cloud top and base as a function of total yield of device. "Equatorial" refers to 0-30 degrees latitude; "polar" refers to 30-90 degrees (Peterson, 1970).

Although there are differences in the values of clouc top and bottom as seen in Figures 2 and 3, we use the Peterson (1970) values in GLODEP2 sinee he obtained reasonable agreement with deposition measurements. Further, in the sample calculation reported in Section $4, I$, excellent agreement with measurements at two locations is shown. This might be an area for further research using GLODEP2. For example, a sensitivity study could be mede on the effects of cloud top and bottom values on the dose when one has multiple bursts sueh as the 1! . oे test series. 


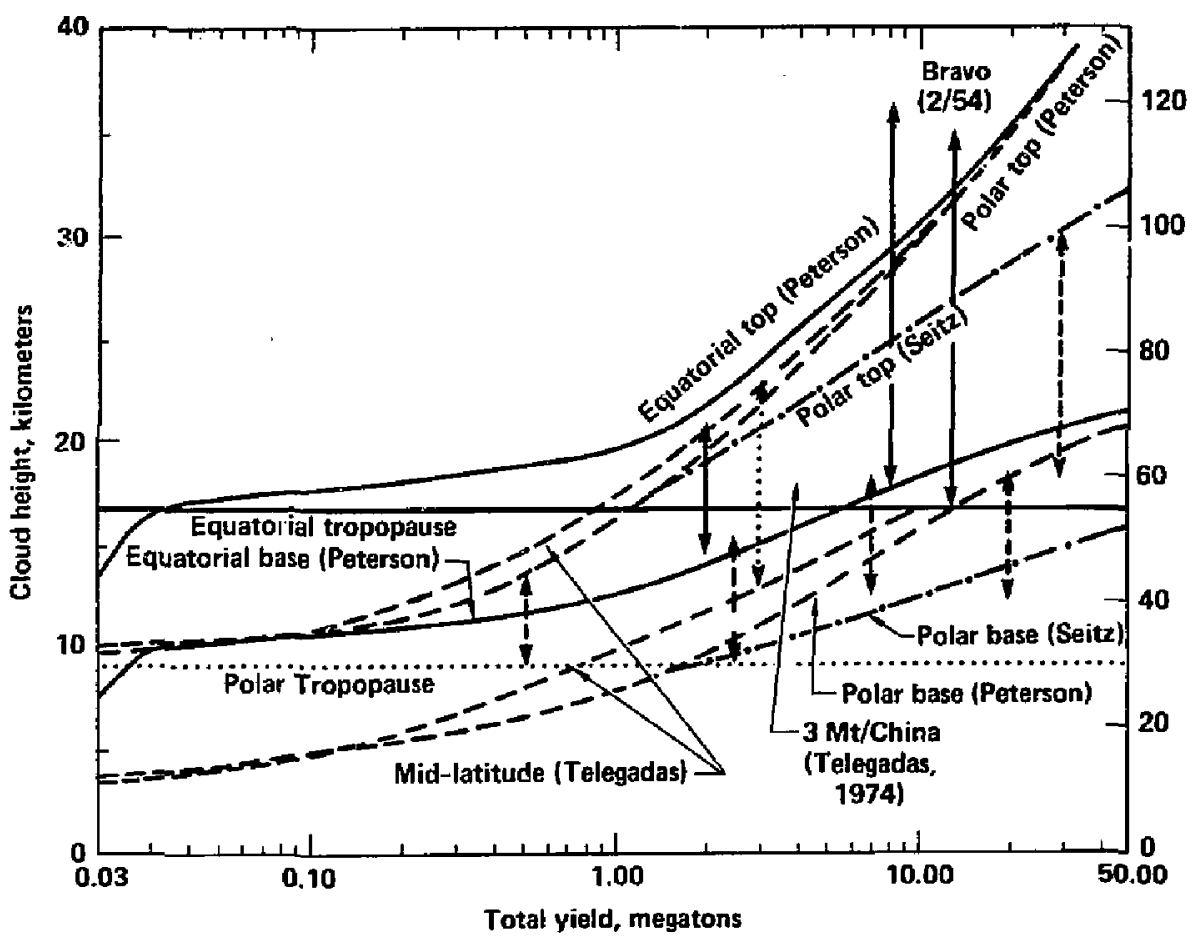

Figure 3. Cloud rise height as a furetion of yield for different latitudes. United States tests were condueted at equatorial latitude $\left(2^{\circ}-17^{\circ} \mathrm{N}\right)$, Chinese at mid-latitude $\left(40^{\circ} \mathrm{N}\right)$, and Soviet at polar latitude $\left(75^{\circ} \mathrm{N}\right)$. Peterson's (1970) curves are based on United States tests; all United States explosives had yields below 15 Mtons. Thus Peterson's equatorial curves for yields above 15 Mtons as well as his polar curves are estimates. Estimates of Seitz et al. (19od) for individual United States (solid) and Soviet (dashed) explosions are shown as vertical lines. Dot-dash curves have been drawn by eye through Seitz' Soviet lines to provide an alternative to Peterson's polar case. Note the significant difference for yields greater than 1.5 Mton. Sorne mid-latitude estimates of Telegadas (1979) are also shown, based on Chinese explosions. (Bauer, 1979.)

The initial vertical distribution of radioactivity within the cloud is a modif ication of Ferber's [9] distribution into seven equal layers as shown in Table 1. This distribution is used directly for airbursts-those in which the fireball does not touch the surface of the earth-with height-of-burst at $3 \mathrm{~km}$ or less. In the remaining eases modifications are made. Based on Table 1, Peterson [5] derived injection tables for both equatorial and polar bursts which are reproduced in Appendix A, Tables A-1a and A-Jb. These tables are used in GLODEP2 as follows: 
The table values are Mtons of total yield injected. These values must be $m$ sltiplied by the fission fraction, $f$, of the device to produce actual Mtons of fission products injected.

The firebali radius, $R$ (in meters), of a nuclear burst may be estimated by

$$
\mathrm{R}=870 \mathrm{Y}^{0.4}
$$

where $\mathrm{Y}$ is the device yield in Mton. Let $\mathrm{H}$ be the device height-of-burst in meters. Then, if

$\mathrm{R}<\mathrm{H} \leq \mathbf{3 0 0 0} \quad-\quad$ use linear interpolation of yield in either Table A-1a or Table A-lb

$0 \leq H<R \quad$ - use a "spherical cap" reduction factor on the table values defined by

$$
P R=1-(R-H)^{2}(2 R-H) /\left(4 R^{3}\right) \quad \text { (Eq. 1) }
$$

$3000<\mathrm{H}$ - find cloud top and bottom in the table value for the appropriate yield. Use logarithmic linear interpolation on yield if necessary. Determine an injection per unit height for each of the etmospheric compartments based on the table values. Adjust the cloud upward by the amount ( $\mathrm{H}-3000)$ meters and apply conservation of amount injected to compute new values of injection in the atmospheric compartments. 
Layer, fraction of

"mushroom cap"

percentage of activity

(from base to top)

within layer

$\begin{array}{rr}0-1 / 7 & 1 \\ 1 / 7-2 / 7 & 14 \\ 2 / 7-3 / 7 & 25 \\ 3 / 7-4 / 7 & 25 \\ 4 / 7-5 / 7 & 15 \\ 5 / 7-6 / 7 & 15 \\ 6 / 7-7 / 7 & 5\end{array}$

Table 1. Initial vertical distribution of radioactivity assumed within "mushroom cap."

Thus, for any single nuclear explosion, given

$i=$ quarter of injection

$Y=$ total yield in Mtons

$H=$ height-of-burst in meters

$\mathrm{f}=$ fission fraction of the device

a = detoriatior. latitude

tnen, using the procedure cutlined abcve, compute

$\mathrm{K}$ = radius of fireball in meters,

$\mathrm{FH}=a$ factor between .5 and 1 . for injection reduction if needed (see Eq. 1), and, using the tables, en injection of fission producis, IF $P$,

$I F P_{j, k}^{i}=f * F R * Y *(\text { Table value based on } d, Y, H)_{j, k}$ (M tons)

for injection quarter $i$, atmospheric compartment $j, k$ for

$\mathbf{k}=$ eitner Polar or Equatorial

j = appropriate tropospheric, lower stretospheric, upper stratospheric or high atmospheric compartment. 
In the case that a nuclear power installation is attacked, we assume that the entire facility is cratered by a surface burst. We further assume that $50 \%$ of the debris is injected into the atmosphere in exactly the same manner as the debris froin the nuclear weapon used in the attack.

Thus, if $m$ nuclear power installations of type $n$ are also attacked by the above device, then we also have those fission produets injected as the fraetional amount of type $n$ facility

$$
N F P_{j, k}^{i, n}=0.5 m_{n}^{*}(\text { Table velue besed on } d, Y, H)_{j, k} / Y
$$

with the essumed 50\% of the facilities fission products injected due to 2 ground-burst weapon. The $i, j$, and $k$ indices have the same meaning as for If $P$.

\subsection{Deposition Model}

In GLObEP2 use is made of Peterson's [5] division of the flobe into nine latitude bands of 20 degrees each. Within each band the surface deposition is assumed to be uniform acound the entire earth. We are concerned with both the intermediate (tropospheric) and long-tern (stratospheric) :allout. The immediate losal fallout is not included in the GLODEP2 model.

\subsection{1 lntermediate Deposition}

It is assumed that the intermediate fallout originates in the tropospheric compartment, and deposition oceurs on a time scale of days to a month or two. In the model this portion of the fallout is contained within the first $9 \mathrm{~km}$ for a polar injection and the first $17 \mathrm{~km}$ for an equatorial injection. We assume the debris cloud encircles the globe, perhaps several times, as a diffusing cloud of decreasing radioactivity. A Gaussian diffusion methodology is employed to model this deposition.

The tropespheric deposition model is based on a Gaussian cloud centered at the detonation latitude with a id degree standard deviation. The Gaussian is superposed over the 20 degree latitude bands. A fractional deposition is assigned to the latitude band that agrees with the area under the Gaussian within the band. Reflection techniques at the North Pole are used to conserve the fractional depositions. Fig. 4 illustrates the procedure. 


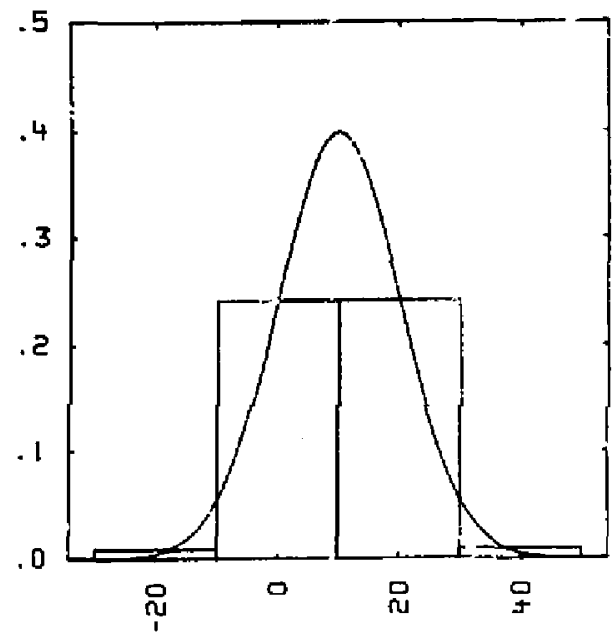

a. Detonation at $10^{\circ} \mathrm{N}$.

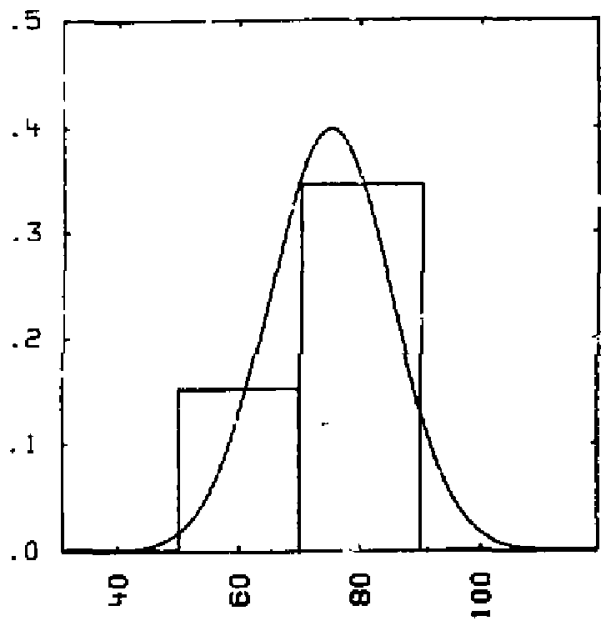

c. Detonation at $20^{\circ} \mathrm{N}$.

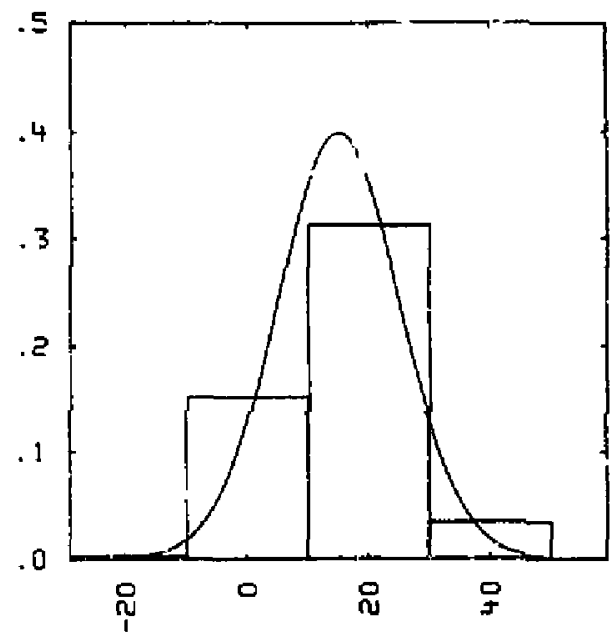

b. Detonation at $15^{\circ} \mathrm{N}$.

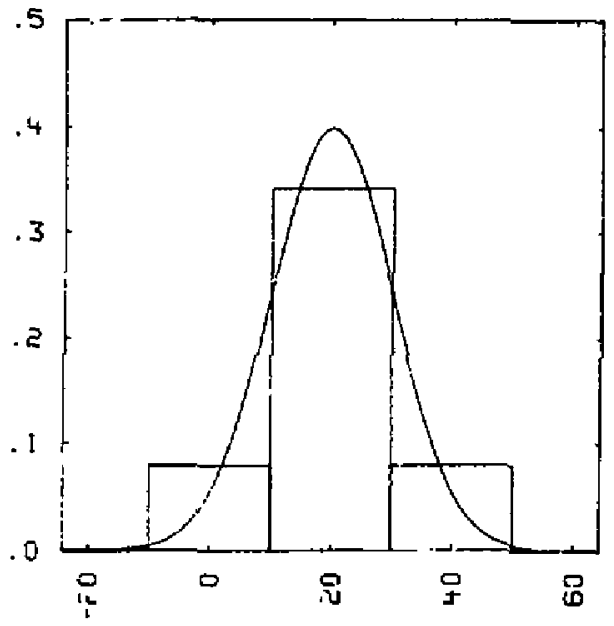

d. Detonation at $7^{\circ} \mathrm{N}$.

Figure 4. Tropospherie deposition fractions for 20 degree latituda bands using a Gaussian distribution about the detonation latitude. Reflection techniques are applied at the North Pole as shown in Figure 4 d.

The deposition fractions associzted with Figure 4 are listed in Table 2. Note that with a Northei i Hemisphere injection, and a iu fegree standard deviation on the Gaussian, there is rio tropospheric deposition in the two southern-most latitude bands. 


\begin{tabular}{llllllll}
\hline $\begin{array}{l}\text { Detonation } \\
\text { Latitude } \\
\text { (Degrees N) }\end{array}$ & 70-90N & $50-70 \mathrm{~N}$ & $30-50 \mathrm{~N}$ & $10-30 \mathrm{~N}$ & $10 \mathrm{~N}-10 \mathrm{~S}$ & $10-30 \mathrm{~S}$ & $30-50 \mathrm{~S}$ \\
\hline & & & & & & & \\
10 (Fig. 4B) & 0. & 0. & 0.0179 & 0.4821 & 0.4821 & 0.0179 & 0. \\
15 (Fig. 4b) & 0. & 0.0 & 0.0668 & 0.6247 & 0.3038 & 0.0047 & 0. \\
20 (Fig. 4c) & 0. & 0.001 & 0.1577 & 0.6826 & 0.1577 & 0.001 & 0. \\
75 (Fig. 4d) & 0.6915 & 0.3038 & 0.0047 & 0. & 0. & 0. & 0. \\
\hline
\end{tabular}

Table 2. Examples of fractional deposition of tropospheric fallout.

Figure 5 , taken from the work of Machta, as reported ir $[14\}$ indicates that measurements of tropospheric fallout are very close to Gaussian with about a 10 degree shandard deviation.

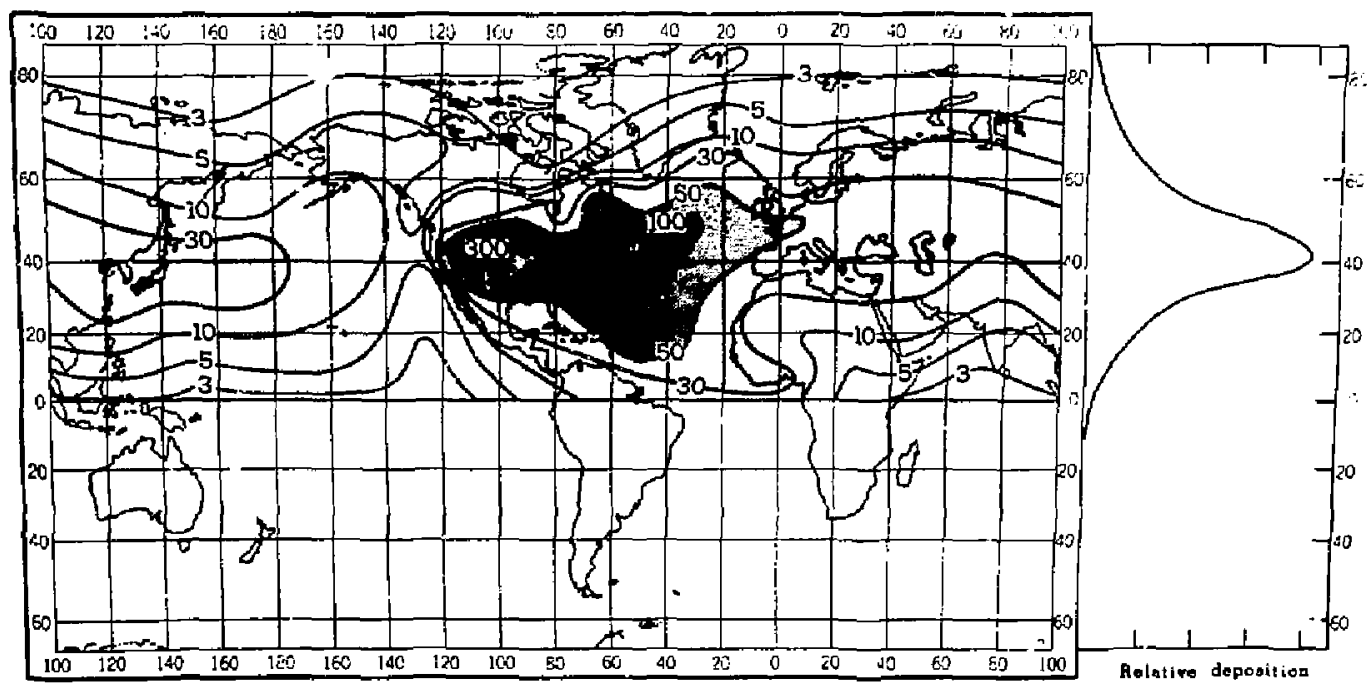

Figure 5. Worldwide fallout of raciogativity from nuclear weapons tests in Nevada in 1953. The explosions were in the kiloton range of yields, and debris was confined to the troposphere. The intensity of fallout is shown in relative units (L. Machta). 
Since the internediate follout always occurs during the first quarter after injection, GLODEP2 allows input of a fraction of the quarter at which time deposition is complete. Then, given the injection of fission products and computing the latitude fractional depositions as above, the surface deposition, WSD, from the troposphere is computed as

$$
W S D_{j, k, b}^{i}=\operatorname{IFP}_{j, k}^{i} * F D_{b} \text { (Mtons of weapons debris deposited) }
$$

where

IF $P_{j, k}^{i}$ is the Mtons of weapons fission products injected (see $E g .2$ ),

$F D_{b}$ is the fractional deposition, and

$i$ is the injection quarter,

$k=1$ for equatorial, $=2$ for polar,

$j=1$ for tropospheric compartment,

$b=1,2, \ldots .9$ for the 20 degree latitude bands from North to South.

In ease of attack on a nuclear power installation, the relative amount of the fission products depogitcd, NSD, is computed by

$$
N S D_{j, k, b}^{i, n}=N F P_{j, k}^{i, n_{*}} F D_{b} \text { (relative amount of type n deposited) }
$$

where $\mathrm{r}$ is the index for the type of nuclear facility and

$N F g_{j, k}^{i, n}$ is the fract ${ }^{-}$inal faeility injected in compartment $j, k$ (see Eq. 3 ).

The remaining indices are as above. 


\subsubsection{Long-Term Fallout and Deposition}

The GLODEP2 fallout model for long-term deposition is identieal with that derived by Peterson [5] based on injections of tracer elements as shown in Table 3.

\begin{tabular}{|c|c|c|c|c|c|}
\hline Compartment & $\begin{array}{l}\text { Data source and } \\
\text { injection date }\end{array}$ & $\begin{array}{c}\text { First } \\
\text { deposition }\end{array}$ & $\begin{array}{l}\text { Maximum } \\
\text { deposition }\end{array}$ & $\begin{array}{l}\text { First half of } \\
\text { deposition }\end{array}$ & $\begin{array}{c}\text { Partitioning } \\
\text { between } \\
\text { nemispheres }\end{array}$ \\
\hline $\begin{array}{l}\text { Lower equatorial } \\
\text { stratosphere }\end{array}$ & $\begin{array}{l}\text { 185W } \\
\text { (May-Aug 1958) }\end{array}$ & lst season & lst spring & 8 months & $2: 1$ \\
\hline $\begin{array}{l}\text { Upper equatorial } \\
\text { stratosphere }\end{array}$ & None & (lst spring) & (2nd spring) & $(2 \mathrm{yr})$ & $(1: 1)$ \\
\hline $\begin{array}{l}\text { High equatorial } \\
\text { atmosphere }\end{array}$ & 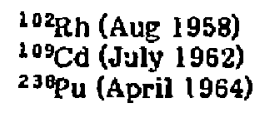 & 2nd spring & 3rd spring & $3-1 / 2$ yr & $2-1 / 2+1$ \\
\hline $\begin{array}{l}\text { Lower polar } \\
\text { stratosphere }\end{array}$ & $\begin{array}{l}89 \mathrm{Sr} /{ }^{90} \mathrm{Sr} \text { ratios } \\
\text { (Oet. 1958) }\end{array}$ & Ist season & 1st spring & 5 II onths & $20: 1$ \\
\hline $\begin{array}{l}\text { Upper polar } \\
\text { stratosphers }\end{array}$ & $\begin{array}{l}{ }^{54} \mathrm{Mn} \\
(1961-62)\end{array}$ & Within 6 months & $s$ 2nd spling & $3 \mathrm{yr}$ & $4: 1$ \\
\hline $\begin{array}{l}\text { High polar } \\
\text { atmosphere }\end{array}$ & None & (2nd spring) & (3rd spring) & $(3-1 / 2 y r)$ & $(2: 1)$ \\
\hline
\end{tabular}

Table 3. Source of tracer date with date of injection and parameters used to prepare deposition tables; parentheses indicate subjective estimates for compartments lacking tracer data (Peterson, 1970 ).

Table 3 indicates information germane to deposition from the various compartments. The parentheses show where "subjective estimates" were necessary since observations were not available. The third column shows the time reguired for stratospheric debris to first reach the surface. As would be expexted, this time increases with height of injection.

The fourth column shows the time after injection for the occurrence of the maximum seasonal deposition. Although the Lower Poler compartment yields relatively higher maximum deposition values than the adjacent equatorial compartment, the time of the maximum is the same and increases with altitude. 
The estimated partitioning between the Northern and Southern Hemisphere within each compartment is shown in the last column.

From the information shown in Table 3, Peterson constructed deposition tables for those compariments within which unique tracer information was not available. Thus, fractional deposition tables were prepared for all injection quarters for all of the stratospheric and high atmospheric compartments. These tables are reproduced in Appendix A.

Then, given the fission products injected in guarter $i$, at detonation latitude, $d$, the surface deposition from the stratospheric and high atmospheric compartments in latitude band $b$ are computed by

$$
w S v_{j, k, b}^{i+q}=I F P_{j, k}^{j} F^{*} \quad F D_{j, k, b}^{i, q} \text { (Mtons of weapons debris deposited) }
$$

where $\mathrm{FD}$ is the fractional deposition from the appropriate table (tables A-2a thru $\mathrm{A}-\mathrm{Zb})$, and

$q=0,1,2 \ldots .23$ is the quarter after injection,

$j=2$ for deposition from the lower stratospheric compartment,

$=3$ for deposition from the upper stratospheric compartment,

$=4$ for deposition from the high atmospheric compartment,

$k=1$ for equatorial injection, $=2$ for polar injection,

and $b=1,2 \ldots 9$ for the letitude bends from North to Sout $h$.

In case of attack on a nuclear power installation, we also compute

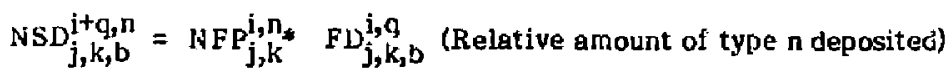

where NFP is thie fraction of type $n$ facility injected and the indices are the same as \&bove.

Note the similarity to tine equations used for the tropospheric deposition in the preceding section. The only difference is that the superseript $q=0$ for the tropospheric (intermediate) deposition, all of which occurs in the first quarter。

\subsection{Gamma-Ray Dose Models}

\subsection{1 "Uniform" Dose Over Latítude Bands}


The curves in Pigure 6 from [4] show the gamma-ray dose rate versus time after detanation for a $1-M$ ton fission weapon (1-MT), the equilibrium core of a light water reactor (CORE), the inventory associated with a 5-ton per day nuclear fuel reprocessing plant that has 10 years of stored high-level waste (HLW), and 10-years of spent fuel stored at a LWR (SF). The units have been corverted to (rem $\left.\mathrm{km}^{2}\right) / \mathrm{ctr}$.

For any given deposition quarter, $p$, numerical integration under the n-th curve, yields

$d_{n}^{p}$ in (rem-km $\left.{ }^{2}\right) /($ unit of device type n) per quarter

as a "dose-area-integral" that properly accounts for the decay law associated with the weapon or nuclear installation.

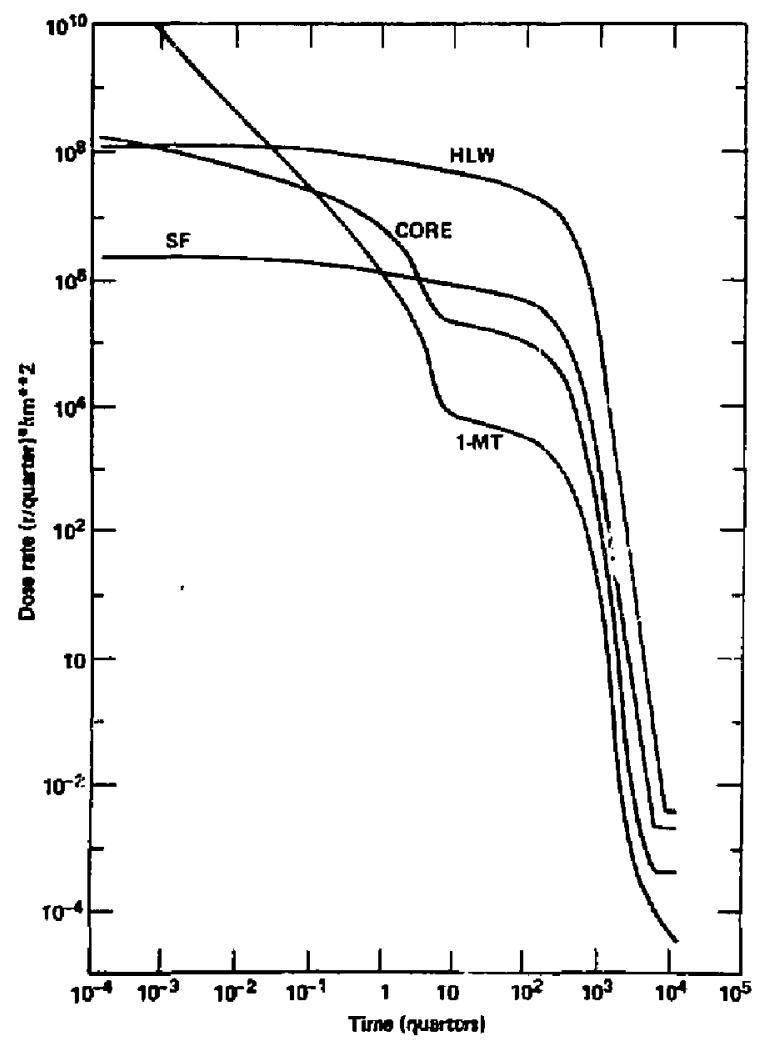

Figure 6. Gemma-ray dose area integral rate versus time after shutdown or detonation (Chester and Chester, 1976). 
We assume a delta function deposition of debris

$W_{j, k, b}^{i+q}$ (weapon) or $\mathrm{NSD}_{j, k, b}^{i+q, n}$ (type n facility)

at the mid-quarter, $i+q$. Then for a single burst injection, the quarterly dose rate in the p-th quarter due to the deposition in the current and earlier quarters is given by

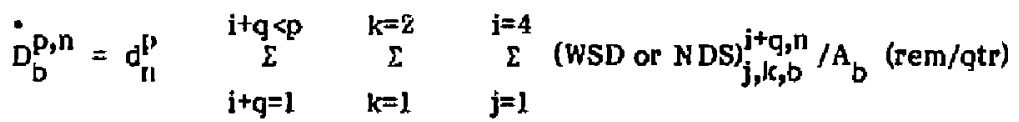

where $A_{b}$ is the area ( $\left.\mathrm{cm}^{2}\right)$ of the b-th latitude bend.

If there are multiple bursts or several nuclear power installations then summation over all of them produces a "totel quarterly" dose rate in the p-th quarter and b-th 20 degree latitude band.

Define lo.er and upper limits for dose exposure by

pi = beginning quarter to start dose exposure, and

pf = final guarter for dose exposure,

e.g., 0 and 200 for a 50-year dose, or, 9 and 10 quarters for a 6 month dose starting 2 years after detonation, then the accumulated gamma-jay dose is computed by

$$
D(p i, p f)_{b}^{n}=\underset{p=p i}{p=p f} \quad \dot{D}_{b}^{p, n} \quad(r e m)
$$

for the n-th fission product source and the b-th latitude band. A sum oven all the $n$ injection sources produces a final gamma dose from pi through pf. 


\subsection{2 "Location" Dose with Weather, Terrain, Penetration and Run-ofé}

Predicting a dose at a specific location requires consideration of all the significant local factors. Factors we have identified are terrain roughness shielding, average local rain rate, runoff and soil penetration. To compere with oisserved gamma radiation fields due to atmospheric testing requires inclusion of these factors in the model used for the predietions.

To incorporate the eifects of non-smooth terrain, the recommendation of Glasstone and Dolan [15] is used. They propose a dose-area integral reduction of thirty percent due to terrain roughness and vegetation shielding. That is, we define a terrain roughness factor, $F_{T}$, where, for moderately rough terrain,

$$
F_{T}=0.7
$$

which reduces the uniform dose rate of the preceding section.

The effect of rainout on accumulation of radiogetivity at different locations is widely observed. The greater the rainf 1 ll at a site, the larger the deposition of tropospheric radioactivity. In fact, for long-range fallout, nearly all of the radioactivity is deposited by rain systems. The GLODEP2 model takes this into account by providing a longitudinal yariation to the latitudinal model predictions based on the rain rate at a given longitude. To establish ine relation between average annual rain rate and deposition rate we use deta accumulated by Lowder et al. [7] as shown in Figure 7. The implication of these data is that the deposition of radioactivity is proportional to the annual average rain rate to the three-fif ths power. Thus, to first order, the ratio of the lacal rate of deposition to the uniform rate for a latitude band is equal to the ratio of the local rain rate to the rain rate a veraged over the latitude band to the three-fifths power. Hence, we define another factor, $F_{R}\left(R, R^{\prime}\right)$, where

$$
F_{R}\left(R, R^{\prime}\right)=\left(R / R^{\prime}\right)^{0.6}
$$

where $R^{\prime}$ is the rain rate at a specific location and $R^{\prime}$ is the latitude band average rain rate. 


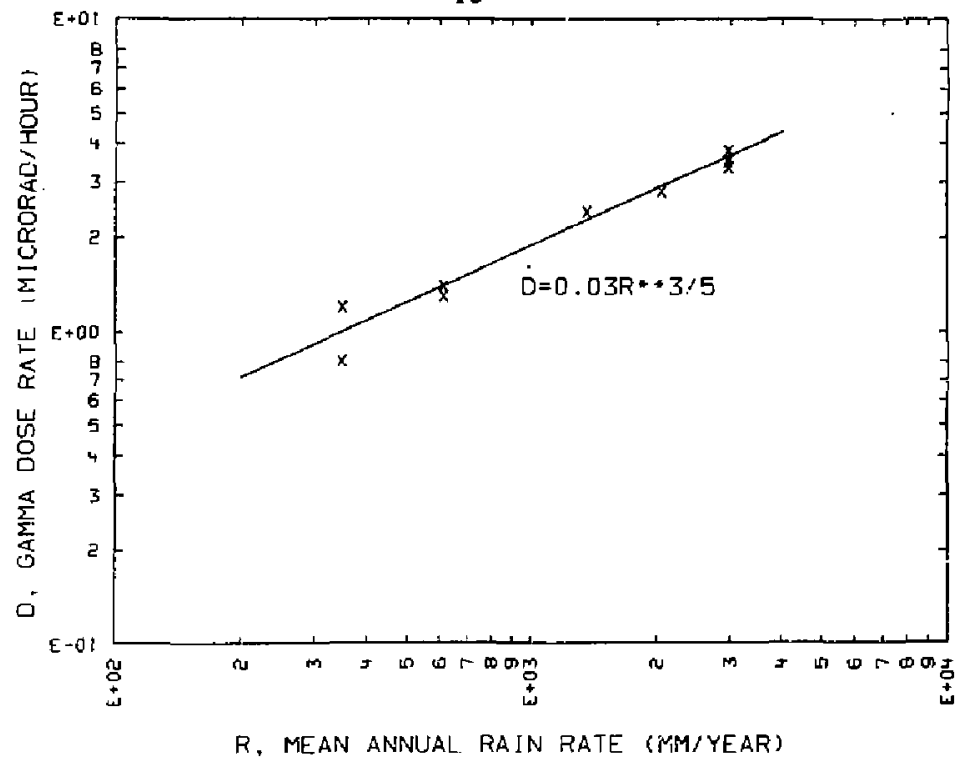

Figure 7. Gamma dose rate (microrad/hr) vs, mean annual rain rate (.nm/y) as measured by Lcider, et al. [T]

After deposition, radioective nuclear debris migrates, albeit at times very slowly. Thus, to make predictions which compare reasonably with observations, account musí be taken of the migration In this model we empirieally account for penetretion and runoff for the simple case of a grassy field. The best data is available for this case. Scenarios such as runoff for metropolitan areas are extremely coruplex and beyond the scope of this work. Consequently, our dose predictions should not be considered appropriate for metropolitan areas, but for typical grassy fields. The person receiving the dose is assumed not to be shielded and remains in the location for the entire period of dose exposure.

Meesurements of weathering of ${ }^{297} \mathrm{Cs}$ has been made in England by Gale et al. [6] We have modified Gale's expression to take into account the different

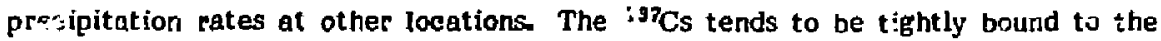
soil particles on which it is doposited. Gale et al have split the ${ }^{137} \mathrm{Cs}$ into $63 \%$ which migrates fairly easily and $37 \%$ which tends to be fairly closely bound to its deposition site. We assume the same split for all the radionuclides. We realize that this assumption may be in error if one considers the faet that the "nuclide retardation factors" vary over several orders of magnitude, dependent on the chemical properties of the nuclide, the nature of the soil, the nature of the water in the soil, etc. To model these teatures in detail introduces a complexity that is beyond the capabilities of the current GLODEP2 model. 
We include the rain rate as a linear proportionality in the weathering reducticn, by defining the weat bered dose factor, $F_{W}(t, R)$, as

$$
F_{W}(t, R)=0.63 \exp (-0.693 R t / 41.8)+0.37 \exp (-0.693 R t / 6320)
$$

where $t$ is the time after deposition and $\mathrm{R}$ is the loeal average annual rain rate.

Finally, the dose rate at a specific location is computed by assuming tho unifo: $n$ dose rates of the preceding section are loc ated at the center of the latitude band. A linear interpolation to the local latitude produces an "unweathered, smooti, terrain" rate, $D^{\prime}(t)$. The final expression for unsheltered, weathered, grassy terrain dose rate at a specific location is

$$
D_{W}\left(t, R, R^{\prime}\right)=F_{T} * F_{R} * F_{W}^{*} D^{\prime}(t)
$$

at time $t$ after deposition

\section{GLODEP2 CODE STRUCTURE AND COMPUTATION AL AI,GORITHMS}

The current version of GLODEP2 is written for the CRAY-1 computer using the LRLTRAN language. The number of subseripts used, certain of the input statements and the graphics package are not directly adeptable tn FORTRAN IV language. Input to the code may be accomplished using an input disk file (see APPENDIX B) or by teletype in a conversational mode.

In this section the basic code structure and the computational algorithms are delineated.

\subsection{Modular Code Structure}

As depieted in Figure 8, GLODEP2 is structured in a modular form to allow further development of models as required with minimum disturbance to the remainder of the eode. 


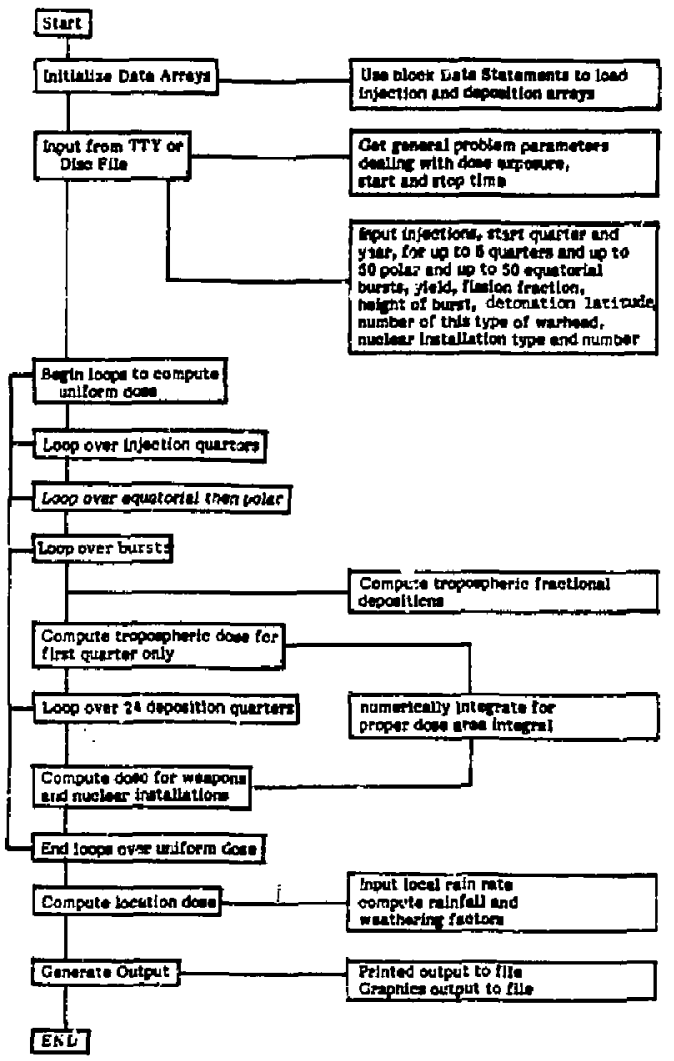

Figure 8. Modular structure of the GLODEP 2 computer program.

\subsection{Data Arrays}

Peterson's [5] deposition arrays are converted from 905r values given in [5] to pure fractions. The standard FORTRAN IV BLOCK DATA statements are used to load:

FIN $J\left(i_{r} j_{,} k\right)$, injection tables $A-1$ a and $A-1 b$, where

$i=1,17$ is a function of total yield in Mtans

$j=1 \quad$ is device total yield

$=2$ is debris cloud top $(\mathrm{km})$

$=3 \quad$ is debris eloud bottom $(\mathrm{km})$ 
and for

$\begin{array}{llcc}j=4 & \text { is Mton of total yield injected } & k=1 \text { (equatorial) } & k=2 \text { (polar) } \\ =5 & \text { is Mton of total yield injected } & 0-17 \mathrm{~km} & 0-9 \mathrm{~km} \\ =6 & \text { is Mton of total yield injected } & 24-50 \mathrm{~km} & 17-50 \mathrm{~km} \\ =7 & \text { is Mton of total yield injected } & >50 \mathrm{~km} & >50 \mathrm{~km}\end{array}$

DTABS $(i, j, k, m\}$, surface deposition tables $A-2,3,5$ and 6 , where

$\mathrm{i}=1,24$ for the 24 quarters of deposition

$j=1,9$ for the 9-20 degree latitude bands from North to South

k=1 [or injections during Dec-Peb

$=2$ for injections during Mar-May

=3 for injections during Jun-Aug

$=4$ for injections during Sep-riov

$m=1$ is fractional deposition from LES (tables $A-2 a, b, c$ and d)

$=2$ is fractional deposition from UES (tables $A-3 a, b, c$ and $d$ )

$=3$ is fractional deposition from LPS (tables A-5a,b,c and d)

$=4$ is fractional deposition from UPS (tables $A-6 a, b, c$ and d)

DTABA $(i, j, k, m)$, surface deposition tables $A-4$ and 7 , where

$i$ and $j$ are as above, and

$k=1$ for injections during Mar-Aug

$=2$ for injections during Sep-Feb

$m=1$ is fractional deposition from HEA (tables $A-4 a$ and $b$ )

$=\&$ is fractional deposition from HPA (tables $A-7 a$ and $b$ ).

These tables are basically fractional depositions for the amount of radioactive debris remaining in the appropriate compartment. If the fractional velues in uny given table (and their indicated extensions) are summed, the sum is very near unity. 


\subsection{Injection Algorithms}

The assumed input consists of

$Y=$ total yield of the device (Mtons)

$\mathrm{H}=$ height-of-burst of the device (meters)

$\mathrm{NW}=$ number of warheads of this type of device at this location

$\mathrm{f}=$ fission fraction of the device

d $=$ detonation letitude of this device

$n=0$ if no attack on a nuclear power installations with this device

$=1$ if attack on reprocessing plant

$=2$ if attack on 30-day spent fuel storage facillty

$=3$ ii attack on $3600 \mathrm{MW}(\mathrm{th}) \mathrm{LWH}$, (steady state)

$=4$ if attack on 10-yr spent fuel storage at reactor facility

$N F=$ number of nuclear facilities of type $n$.

Then compute

$I=1$ if $0 \leq d \leq 30$, an equatorial injection

$=2$ if $30<d \leq 90$, a polar injection,

$R=870 \mathrm{Y}^{0.4}$

0.5 if $\mathrm{H}=0$

$F R=\{1.0$ if $H \geq R$

1. $-(H-R)^{2}(2 R-H) /\left(4 R^{3}\right)$ if $0<H<K_{\text {, }}$

a hejght-of-burst factor.

Next the fractional injections are computed using the appropriate table FIN $J(i, j, I)$. If $I=1$, then $I B=16$, otherwise, $I B=I 7$, and

$$
\begin{aligned}
& \text { if } Y<\operatorname{FIN~}(1,1, I) \text {, set } I N=1 \text { and } X=0 \text {, } \\
& \text { if } Y>\text { FIN } J(I B, 1, I) \text {, set }[\mathrm{I}=1 \mathrm{IB} \text { and } X=0 \text {, } \\
& \text { if } Y=F 1 N J(i, 1, I) \text {, set } 1 N=i \text { and } X=0 \text {, otherwise } \\
& \text { if } \operatorname{FINJ}(i, 1,1)<Y<\operatorname{PINJ}(i+1,1, I) \text {, set } I N=i \text { and } X=(X-F I N J(i, 1, I) \text { / } \\
& \text { (FIN J(i+l, } 1, \text { I)-FIN J(i, } 1,1) \text {. }
\end{aligned}
$$

Then, using the interpolation if necessary, obtain the injection fractions by 
$x(i)=\operatorname{FIN} J(I N, i, l)+X *($ FIN $J(I N+1, i, 1)-F I N J(I N, i, 1))$

for $i=1$, troposphere

$=2$, lower stratosphere

$=3$, upper stratosphere

$=4$, high atmosphere.

If $\mathrm{H}>3000$, adjust the $\mathrm{x}(\mathrm{i})$ by the amount $\mathrm{DH}=\mathrm{H}-3000$ as follows:

Let $X L=0$ if $X=0$, otherwise

$\mathrm{XL}=\log (\mathrm{Y} / \mathrm{FINJ} \mathrm{IN}, 1, \mathrm{I}) / \log (\mathrm{FINJ}(\mathrm{IN}+1,1, \mathrm{I}) / \mathrm{FINJ} \mathrm{IN}, 1,1))$,

ard compute elosd top and bottom

$c t=F I N J(I N, 2,1)+X L(F I N J(I N+1,2,1)-F I N J(I N, 2, I))$

$c b=$ FIN $J(I N, 3,1)+X L(F I N J(I N+1,3,1)-F I N J(I N, 3, I)$.

The new cloud top and botiom are then defined to be

etn $=e t+D H$

$\mathrm{cbn}=\mathrm{cb}+\mathrm{DH}$

Next adjust the $x(i)$ values by conservation of injection. For example if $I=1$ and eb $<17$, ct $>1 \tilde{f}$, cbn $<1$, then

$$
\begin{aligned}
& x(1)=x(1)(17-c b n) /(17-c b) \text { and } \\
& x(2)=x(2)+x(1)(c b n-c b) /(17-c b)
\end{aligned}
$$

The remaining levels wotld also be adjusted by the same technique.

Then, for each burst of injection information, store the arruy

RIN J(g, L,i,j), where 
$q=$ quarter of injection, $1 \leq q \leq 6$, and $q=1$ corresponds to the start of injection quarter and year,

$I=1$ is equatorial, $=2$ is polar,

i=burst number for this quarter, $1 \leq \mathrm{i} \leq 50$,

$j=1$ is $x(1)$, fractional injestion into the troposphere,

$=2$ is $x(2)$, fractional injection into the lower stratosphere,

$=3$ is $x(3)$, fractional injection into the upper stratosphere,

$=4$ is $x(4)$, fractional injection into the high atmosphere,

$=5$ is $Y^{*} N W$, total yield in Mitons for this burst,

$=6$ is $n$, the type of nuclear installation,

$=7$ is $\mathrm{f}^{*} \mathrm{FR}$, the fission product reduetion factor,

$=8$ is $N F$, the number of type $n$ installations, if any,

$=9$ is $\mathrm{d}$, the detonation latitude.

\subsection{DEPOSITION ALGORITHMS}

\subsubsection{Intermedizte Fallout}

The intermediate deposition from the troposphere occurs on a tiine scale of days to a month or two. We assume the deposition occurs at an "ingut" fraction of the first quarter and that it can be modelled using a Gaussian distribution about the detonation latitude, $d$. The fractional deposition i. to the 20 degree latitude bands cissurning a 10 degree standaro deviation on the Gausstan is computed.

A funetion, GETx(x), is defined to use linear interpolation on a standard normal $(0,1)$ set of data to get the area under the Gaussian eurve from 0 to tise distance $x$.

The computation is then done as follows:

For any given burst, $i$, in guarter $q$, we have from above,

$d=R I N J(g, 1, i, 9)$, the detonation latitude, and

$f \mathrm{i}=\mathrm{R} I \mathrm{~N} J(\mathrm{q}, \mathrm{I}, \mathrm{i}, 1)$, the fractioral injection in the troposphere. 
We then determine the latitude band in which $d$ is located, i.e., $b^{\prime}$ such that

$\left(90-20\left(b^{\prime}-1\right)\right) \geq d>\left(90-20 b^{\prime}\right)$,

then

if $b^{\prime}=1$, xhi=3.4 (to reflect at North pole)

if $b^{\prime}=1$, xhi $=\left[90-20\left(b^{1}-1\right)-d\right] / 10$

if $o^{\prime} \neq 5, \times 10=\left[d-\left(90-20 b^{\prime}\right)\right] / 10$

if $b^{\prime}=5, \times 10=[d+10] / 10$ (to compute about the equator), and then

FRD $\left(b^{\prime}\right)=\operatorname{GETA}\left(\mathrm{xhi}^{\prime}\right)+\mathrm{GETA}(\mathrm{xlo})$ (area above $d+$ area below $d$ in band). if $b^{\prime}=1$, then set

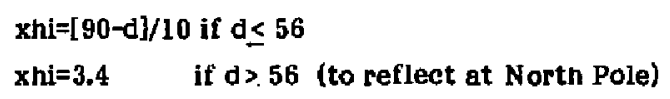

and compute

$\operatorname{FRD}(1)=G E T A(x h i)-G E T A([70-d] / 10)-G E T A([90-20 b-d] / 10)$.

For $b=5$ and $b \neq b^{\prime}$, about the equator, compute

FRD(5) $=$ GETA $([10-d] / 10)+G E T A([10+d] / 10)$.

For $b=6$ and 7 ,

FRD $(b)=G E T A([d+10+20(b-5)] / 10)-G E T A([d+10+20 b] / 10)$.

Since with a Northern Hemisphere detonation and a standard deviation of 10 degrees about $d$, there will be no significant area in the two southern-most bands set

\section{$\operatorname{FRD}(B)=F R D(9)=0$.}

Finally, the surface deposition due to intermediate fallout from the troposphere for this butst at latitude $d$ is calculated $b$ first computing the FRD array as above, then multiplying by the tropospneric injection. That is, a fractional deposition for this burst is computed by

$$
\operatorname{TPD}(\mathrm{q}, 1, \mathrm{i}, \mathrm{b})=\mathrm{FRO}(\mathrm{b}) * \operatorname{RIN} J(\mathrm{q}, \mathrm{I}, \mathrm{i}, 1) \text {. }
$$

This calculation is repeated over the injection quarters, $g=1,6$; the equatorial, $l=1$, and polar, $I=2$; and over all $i$ bursts within each $q$ and $l$. 


\subsubsection{Lono-Term Fallout}

The long-term deposition from the lower stratosphere, upper stratosphere and high atrnosphere is done directly using the data-loaded tables. An input start quarter, iq, is assumed where

iq=1 if first injection in Dec-Feb

icF 2 if first injection in Mar-May

iq $=3$ if first injection in Jun-Aug

iq $=4$ if first injection in Sep-Nov.

The $q=1$ corresponds to $i q, q=2$ to $1 q+1, \ldots, q=6$ to $i q+5$. To select the proper deposition table, set

$$
\begin{aligned}
& \text { iq }=i q+(q-1) \text { if iq } \leq 4 \\
& \text { iq=iq+(q-1)-4 otherwise, } \\
& k q=1 \text { if } i q=2 \text { or } 3, \\
& k q=2 \text { if } i q=1 \text { or } 4 .
\end{aligned}
$$

For each of the $g$ injection quarters and for $I=I$ and $I=2$, and for each of the $i$ bursts within each $g$ and $\mathfrak{l}$ compute

$\operatorname{SFD}(q, I, j, b, n, l)=D T A B S(n, b, i q, 2 *(I-1)) * R I N J(q, I, i, 2)$, the fraetional deposition from the lower stratosphere.

$\operatorname{SFD}(q, 1, i, b, n, 2)=D T A B S(n, b, i q, 2 *$ i) *RINJ(q,I,i,3), the fractional deposition from the upper stratosphere,

$\operatorname{SFD}(q, I, j, b, n, 3)=D T A B A(n, b, k q, d) * \operatorname{RIN} J(q, I, i, 4)$, the fractional depasition from the high atmosphere,

where $n=1,2, \ldots, 24$ for the deposition quarters, and $b=1,2, \ldots, 9$ for the 20 degree latitude bands from North to South. 


\subsection{GAMMA DOSE MODEL ALGORITHMS}

\subsection{1 "Uniform" Dose Over Latitude Bands}

The curves in Figure 6 in Section 2.3.1 show the garnma-ray dose rate versus time after detonation or shutdown for

$$
\begin{array}{ll}
N=1, & \text { a } 1-M t o n \text { fission weapon, } \\
N=2, & \text { a reprocessing plant, 10-yr high-level waste storage, } \\
N=3, & 30 \text {-day spent fuei storage } \\
N=4, & 3600-M W(t h) L W R \text { (steady state) } \\
N=5, & 10-y r \text { spent fuel storage at reactor. }
\end{array}
$$

In GLODEP2 we assume that these curves may be represented by piecewise functions of time of the form

$$
q(t)=g(t))(t-t))^{x} \text { for the space } t l \leq t \leq t u \text {. }
$$

Taking the logarithm, we abtain the slepe in log-log space,

$$
x=\log [q(t u) / q(t)] / \log [t u / t 1]
$$

Then, the area under the curve from some value, tlo, to the higher value thi. is the sum of the piecewise integrations.

Enough points nave been "data-loaded" to reasonably approximate the eurves of Figure 6. Thus we can generate the arrays

$\mathrm{TG}(\mathrm{L})$, an array of times in quartess, $\mathrm{L}=1,73$, and

$\mathrm{G}(\mathrm{N}, \mathrm{L})$, an array of dose rates in (rem $\left.\cdot \mathrm{km}^{\mathrm{2}}\right)$ /quarter

fo: the $N=1,5$ as above, and $L=1,73$. Then, given the $N$, tlo and thi, compute the "dose-area-integral" as follows: 


\section{Determine}

$L^{\prime}$ sueh that ' $f G\left(L^{\prime}\right) \leq t 10<\mathrm{TG}\left(L^{\prime}+1\right)$, and

$L^{\prime \prime}$ such that $T G\left(L^{n-1}\right)<$ thi $\leq T G\left(L^{n}\right)$,

then, for

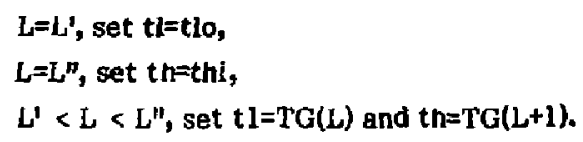

In the computation of dose, assume $p^{\prime}$, the quarter in which to start dose exposure, and $p^{m,}$ the guarter after which the dose integration ends are given. For example, a 50-year dose starting immediately after injection would have $p^{\prime}=0$ and

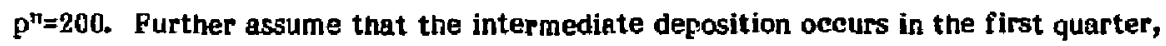
$p^{\prime}$, starting at some fraction of the quarter, pf.

For each burst, $i$, in injection quarter $q$, and for both equatorial, $I=]$, and polar, $I=2$, and for each latitude band, $b$, compute dose rates for the $p$-th quarter, $\mathrm{p}=\mathrm{p}^{\prime}, \ldots . ., \mathrm{p}^{\mathrm{H}}$, as follows :

For the tropospheric deposition, if $p^{x=1}$, then

$$
\text { DDOTH( }(g, q, i, L, b, N, 1)=D A I(N, \rho f, 1) * T F D(q, i, b b) * F M
$$

where $F M \quad=\operatorname{RINJ}(g, I, i, 5) * R I N J(g, I, i, 7)$ if $N=1,(=Y * N W * f * R R$ for weapons)

$=$ RIN $J(g, l, i, 8)$ if $N \neq 1,(=N F$, the number of nuclear installations of type $N$, where $N=R I N J(q, I, i, 6)+1)$.

If $\mathrm{p}^{\prime \prime}>1$, then DDOTN $(\mathrm{g}, \mathrm{j}, \mathrm{I}, \mathrm{b}, \mathrm{N}, 1)=0$. 
Similarly, for the long-term ceposition, compute for

$p=$ maximum $\left(p^{\prime}, n\right)$ through $p=p^{\prime \prime}$, and for

$n=1$ through $n=$ minimum $\left(24, \mathrm{P}^{\prime \prime}\right)$

$\operatorname{DDOTN}(\mathrm{p}, \mathrm{q}, \mathrm{i}, \mathrm{I}, \mathrm{b}, \mathrm{N}, \mathrm{n})=\operatorname{DAI}(\mathrm{N}, \mathrm{p}-\mathrm{l}, \mathrm{p}) * i \operatorname{SPD}(\mathrm{q}, \mathrm{I}, \mathrm{i}, \mathrm{b}, \mathrm{n}, \mathrm{l})+\operatorname{SFD}(\mathrm{q}, \mathrm{I}, \mathrm{i}, \mathrm{b}, \cdots, 2)$ $+\operatorname{SFD}(\mathrm{q}, \mathrm{l}, \mathrm{i}, \mathrm{b}, \mathrm{n}, 3)\} * \mathrm{FM}$

where $F M$ is as above.

If the DDOT $N$ are summed over all $N, q, i$ and $I$, then divided by the area of the latitude band $b$, we obtain a quarterly dose rate

$\operatorname{DDOT}(p, b)(r e m / q t r)$ for the band $b, b=1,2, \ldots, 9$ and for the $p^{-t h}$ quarter, $p=p^{\prime}$, $p^{\prime}+1, \ldots, p^{n}$.

Finally, summing over the quarters, $p=p^{\prime}, p^{1+1, \ldots p^{\prime \prime \prime}}$ gives the accumulated "uniform" gamma-ray dose

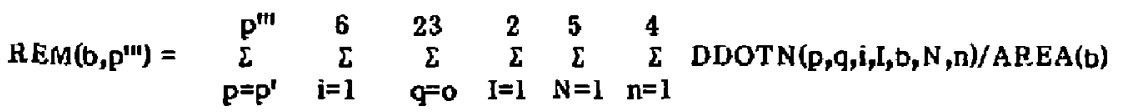

for latitude band $b$ through quarter $p^{m}$.

\subsection{2 "Location" Dose}

The dose at a specific location is computed using both the local average rainfall and an average rainfall in the latitude band. For computational purposes we have data-loaded the array rainl(2,k) using Figure 9.6 on page 370 of Lamb [16] Here pain $(1, k)$ is the latitude of measurement $k$ and rain $(2, k)$ is the average annual rainfall in $\mathrm{mm}$ as shown in Table 4. 


$\begin{array}{ll}\text { Latitude } & \text { Average Annual } \\ \text { Measurement } & \text { Rainfall (mm) }\end{array}$

\begin{tabular}{rrr}
85 & $N$ & \\
75 & $N$ & 115 \\
65 & $N$ & 210 \\
55 & $N$ & 430 \\
45 & $N$ & 740 \\
25 & $N$ & 915 \\
15 & $N$ & 540 \\
5 & $N$ & 1140 \\
5 & $S$ & 1860 \\
20 & $S$ & 1430 \\
25 & $S$ & 1090 \\
35 & $S$ & 860 \\
45 & $S$ & 920 \\
55 & $S$ & 1200 \\
65 & $S$ & 1030 \\
75 & $S$ & 430 \\
85 & $S$ & 100 \\
& & 30 \\
\hline
\end{tabular}

Table 4. Latitude of measurement and average annual rainfall measured as extracted from Figure 9.6 of [16]

Given the local latitude, $\mathrm{dl}$, and the average local rainfall, $\mathrm{r}$, in $\mathrm{mm}$, then linear interpolation in Table 4 is used to obtain a latitude average rainfall, $r$, at $\mathrm{dl}$.

To account for run-off and penetration, a modified version of the model proposed by Gale [6] is used. We compute a reduction factor, FRP, by

$F R P(p, n)=0.63 \exp (-(4.14 e-4) R t)+0.37 \exp (-(2.74 e-6) R t)$

where $t$ is the time in quarters since depasition, i.e., $p-n$ for the factor in the $p-t h$ dose quarter for the n-th quarters deposition. The modificaticn to the Gale madel is only in the coefficients in the exponentials. Here we have divided Gale's coefficients by the average annual rainfall in Grove, U.K., and converted to time in guarters. 
To account for the rate of deposition due to local rainfall, define a deposition factor, FKF, based on data taken by Lowder, et al., [7] Thus

$F R F=\left(R / R^{\prime}\right) \quad 0.6$

is a rainfall multiplication factor.

Glasstone [15] suggests that a "terrain roughness" factor, RF, of about 0.7 should be used to reduce theoretical values to that actually observed in measurements for moderately rough terrain.

Assume that the uniform quarteriy dose rate DDOTN $(p, q, i, L, b, N, n)$ of the previous section is located at the center of the 20 degree band; then let:

$$
\begin{aligned}
& c l(b)=90-20^{*}(b-1) \\
& \text { then, if } c l\left(b^{\prime}\right) \leq d l<c l\left(b^{\prime}+1\right), \text { let } \\
& d^{\prime}=d l-c l\left(b^{\prime}\right) \text {, and } \\
& d^{\prime \prime}-c l\left(b^{\prime}+1\right)-d l
\end{aligned}
$$

be the linear interpolating distanees. The local quarterly dose rates are compited by

$$
\begin{aligned}
& \text { DDOT } N L(p, q, i, L, d l, N, n)=F R P(p, n) * F R R^{*} R F *\left[d l^{1 *} D D O T N(p, q, i, L, b ', N, n)\right. \\
& \text { /AREA(b')+dl*DDOTN } \left.\left(p, q, i, l, b^{\prime \prime}, N, n\right) / A R E A\left(b^{\prime \prime}\right)\right] /\left(c l^{\prime}+d l^{\prime \prime}\right) \text {. }
\end{aligned}
$$

As before, summation over $g, i, L, N$ and $n$, gives the quarterly dose rate for specific location dl, gives

DDOTL(p,dl) (rem/gtr) for the p-th quarter.

Summation over the quarters, $p=p^{\prime}, p^{\prime}+1, \ldots p^{m}$ gives the accumulated gamma-ray dose at the speeific location, $\mathrm{dl}$, with $\mathrm{R} \mathrm{mm}$ of local rainfall

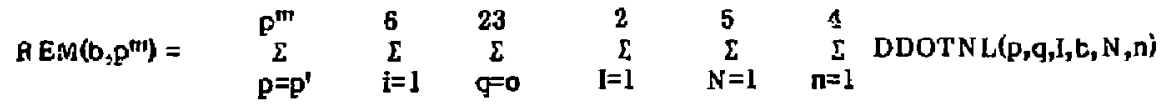

through quarter $\mathrm{p}^{\mathrm{m}}$. 


\section{SAMPLE CALCULATIONS WITH GLODEP2}

In this section two calculations performed with the GLODEP2 code are presented. The first is a series of runs based on the atmuspheric nuclear tests of devices over 100 ktons during 1951-1962 [17] This ealeulation provides a code comparison with dete.

The seeond calculation deals with the gamma-ray dose effects that would be expected in the case of a large scale nuclear exchange between the U.S. and the U.S.S.R. $\{17,18\}$

\section{1 1951-1962 ATMOSPHERIC TESTS}

Using tables such as those in Appendix B of Glasstone [15 Table 2 of Bauer [13] and Teble 1 of the 1982 UNSCEAR [19] report, a series of calculations based on the atmospheric tests during the period of 1951-1962 have been constructed. Only those tests with yields greater than $100 \mathrm{kton}$ have been used since lower values will not inject significant amounts of radioactive debris into the stratosphere. The atmospheric tests conducted by the French and Chinese have been omitted since significant deposition due to the tests would occur after the 1967 time period of interest. 'Table 5 depicts the number of atmospherie nuclear tests in approximate ranges of total yield as used in our study.

\begin{tabular}{lccccccccc}
\hline \multicolumn{7}{c}{ Approximate Total Yield (Mtons) } \\
\hline Year & $.1-.29$ & $.3-.49$ & $.5-.99$ & $1 .-1.9$ & $2-4.9$ & $5 .-9.9$ & $10 .-1$ & 9.9 & $20 .-60$. \\
\hline 1951 & 1 & 0 & 0 & 0 & 0 & 0 & 0 & 0 \\
1952 & 0 & 0 & 1 & 0 & 0 & 0 & 1 & 0 \\
1953 & 0 & 1 & 0 & 0 & 0 & 0 & 0 & 0 \\
1954 & 1 & 0 & 0 & 1 & 0 & 0 & 3 & 0 \\
1955 & 1 & 0 & 0 & 1 & 0 & 0 & 0 & 0 \\
1956 & 1 & 2 & 0 & 2 & 4 & 0 & 0 & 0 \\
1957 & 2 & 0 & 3 & 2 & 2 & 0 & 0 & 0 \\
1958 & 6 & 6 & 3 & 7 & 8 & 4 & 0 & 0 \\
1961 & 1 & 1 & 3 & 4 & 7 & 1 & 1 & 1 \\
1962 & 9 & 3 & 10 & 5 & 9 & 4 & 3 & 4 \\
\hline Total & 22 & 13 & 20 & 22 & 30 & 10 & 0 & 5 \\
\hline
\end{tabular}

Table 5. Number of atmospheric nuelear tests and approximate ranges of total yield in Mtons for the years 1951-1962. 
To compare with measurements at Grove, U.K. [20] for 1951-1967, and at Chiba, Japan [21,22,23,24] for 1962-1967, the accumulated uniform dose for these periods is calculated. Gamma dose with weathering, run-off, penetration and roughness are then computed at these locations.

Table 6 is a summary of the uniform gamma dose aceumulted through 1967 for each of the nine 20-degree latitude bands numbered from North to South. The table values are in mrem.

\section{Latitude Band}

\begin{tabular}{|c|c|c|c|c|c|c|c|c|c|}
\hline Souree & 1 & 2 & 3 & 4 & 5 & 6 & 7 & 8 & 9 \\
\hline $\begin{array}{l}\text { U.S. } \\
\text { U.K. } \\
\text { U.S.S.R. }\end{array}$ & $\begin{array}{r}11.0 \\
1.7 \\
302.3\end{array}$ & $\begin{array}{c}46.7 \\
7 . \\
242.5\end{array}$ & $\begin{array}{r}77.4 \\
10.4 \\
293.4\end{array}$ & $\begin{array}{r}111.4 \\
32.5 \\
83.2\end{array}$ & $\begin{array}{r}93.8 \\
88.6 \\
8.6\end{array}$ & $\begin{array}{c}28 . \\
18.3 \\
9.1\end{array}$ & $\begin{array}{r}37.4 \\
4.2 \\
18.5\end{array}$ & $\begin{array}{r}27.9 \\
3.2 \\
12.6\end{array}$ & $\begin{array}{l}2.6 \\
0.02 \\
2 .\end{array}$ \\
\hline Total & 315.8 & 296.2 & 381.2 & 227.1 & 191. & 55.4 & 60.1 & 43.7 & 4.62 \\
\hline
\end{tabular}

Table 6. Uniform gamma-ray dose (mrem) accumulated through 1967 for atmospheric nuclear tests of 1951-1962.

The gamma dose as measured and computed at two specific locations are shown in Table 7. The agreement, even though it may be somewhat fortuitous, is remarkably good.

We acknowledge that our penetration, run-off and rainfall models are derived primarily from measurements at Grove. However, large portions of these data were obtained from independent, controlled experiments. Further, the injection and deposition models are independent of these dat $\mathrm{s}$.

We do note that the values computed for Chiba use the GLODEP2 models directly with no fitting of parameters to the measurements reported there. 
Grove, U.K. Chiba, Japan

Latitude

Local average Rainfall $(\mathrm{mm})$

Latitude A verage Rainfall $(\mathrm{mm})$

Computed dose (mrem)

Measured dose (mrem)

$55.0 \mathrm{~N}$

683

843

140

131

Table 7. Measured and Computed gamma doses at Grove, U.K. (accumulated from 1951 to 1962), and at Chiba City, Japan (accumulated from 1962 to 1967).

\subsection{HYPOTHETICAL LARGE-SCALE NUCLEAH WAR}

A study of the available strategic inventories of the two superpowers indicates that about 14000 Mton is hypothetically available, but a more likely, but not implausible, strategic exchange is about 5300 Mton. This exchenge would be composed of land-based, subnarine, and aircraft delivered nuclear weapons of the U.S. and U.S.S.R. targeted on military installations, industrial centers, and urban areas. Fo: the purposes of this example of non-local radionuclide effects, we have used the mix of warhead yields and fission yialds shown in Table 8.

The application of GLODEP2 models to this type of scenario assumes that if, in fact, there is a "nuclear winter" following the exchange, the effects produce only minor perturbations on the empirically derived deposition models.

\begin{tabular}{cccc}
\multicolumn{2}{c}{ U.S.S.R. Weapons } & \multicolumn{2}{c}{ U.S. Weapons } \\
$\begin{array}{c}\text { Total Fission } \\
\text { Yield/Warhead } \\
\text { (Mton) }\end{array}$ & $\begin{array}{c}\text { Yield Injected } \\
\text { (Mton) }\end{array}$ & $\begin{array}{c}\text { Yield/Warhead Fission } \\
\text { (Mton) }\end{array}$ & $\begin{array}{c}\text { Yield Injected } \\
\text { (Mton) }\end{array}$
\end{tabular}

$\begin{array}{lr}20 . & 305 . \\ 1 . & 70 . \\ 0.9 & 675 . \\ 0.75 & 15 . \\ 0.55 & 220 . \\ 0.2 & 5 .\end{array}$

$\begin{array}{lll}705 . & 9 . & 235 . \\ 70 & 1 .-2 . & 285 .\end{array}$

75.

$15 . \quad .1-.2105$

0. 1.1 .

Total Mton injected 1290.

741.

Table 8. Hypothetical Strategic Exchange Scenario (\#). 
\# The estimates of available stockpiles used in developing Table 6 are drawn from IISS [25] and Cotter et al. [26] We have made arbitrary, but plausible, assumptions concerning number of warheads used, fission/fusion fraction, height of burst, etc. It should be recognized that these are hypothetical excharges and their publication and use does not imply any relationship to the plans of either the United States or the Soviet Union.

We assume that the attack on the U.S. is all injected at 39 degrees North latitude, and that on the U.S.S.R. is injected at 50 degrees North latitude. Of the approximate 2031 Mton of fission products injected, II\% (224 Mton) goes to the troposphere, 61\% (1237 Mton) goes to the lower polar stratosphere, and 28\% (570 intonj is placed in the upper polar stratosphere.

In addition to the weapons exchange indicated above, we assume an attack on an approximate ijo $\mathrm{GW}(\mathrm{e})$ nuclear power incustry in the U.S. We assume $0.9 \mathrm{Mton}$ weapons are surface bursts on $100 \mathrm{LWR}$ 's, 100 10-yenr Spent Fuel storage (SFS) facilities, and 1 Federal Reproeessing Plant (FRP). With a 0.9 Mton burst on each facility, $1.8 \%$ of the fission products are injeeted in the troposphere and $48.2 \%$ into the lower polar stratosphere.

The resulting uniform unsheltered, unweathered doses are shown in Table 9. The largest value of $23 \mathrm{rem}$ for the weapons ( 84.6 for weapons pluse the $100 \mathrm{GW}(\mathrm{e})$ nuclear power industry) is computed in the 30-50 degree North Latitude Band.

If one assumes that the general eirculation pattern of the atmosphere remains unchanged due to the strategie interchange, then the GRANTOUR model designed by Walton and Maccracken [26] may be used to compute local "hotspots" due to nuclear destis eloud interactions with storm clouds. Based on such calculations, Knox [18] leports:

"Depending on season, meteorological conditions during the exchange, and how soon the debris clouds intercept large scale weather systems, the tropospheric portion of the radionctive inventory can be scavenged by precipitation and hotspots of deposited radioactivity can occur with doses of about 70 rem (winter) to 40 to 110 rem (summe) in regions like Europe, western Asia, western North Pacific, southeastern U.S., northeastern U.S., and Canada. Such regional hotspots have been identified by numerieal simulation of 
interaction of the debris cloud with precipitation systems as depicted in the Oregon State University (OSU) general girculation model."

Inclusion of the effects of an attack on the $100 \mathrm{GW}(\theta)$ nuclear power industry would indicate similar hotspots, i.e., of the order of 200-300 rem.

As pointed out by Walton [26] these GRANTOUR caleulations use a specific sequence of meteorologir "- events as calculated by the OSU general circulation model. For a different starting time or altered circtilation model, which would place precipitation systems differently, results could be very different.

Figure 9 is contous plot of the fractional deposition. Figure 10 shows the fractional depositions over the 24 quarters for each of the 20 degree latitude bands. In these figures we observe the effects of seasonal rainfall on the deposition. One observes the largest deposition at $30-50 \mathrm{~N}$ and the smallest, 3-4 orders of magnitude smailer, at 70-90s. Further, no deposition occurs in the southernmost latitude band for the first 6 months after the exchange.

\begin{tabular}{lcccccccccc}
\hline \multicolumn{10}{c}{ Latitude Band } \\
\hline Source & 1 & 2 & 3 & 4 & 5 & 6 & 7 & 8 & 9 \\
\hline Weapons & 3.65 & 18. & 23. & 5.7 & 0.76 & 0.55 & 0.78 & 0.47 & 0.08 \\
LWR & 1.75 & 6.27 & 8.94 & 3. & 0.56 & 0.27 & 0.25 & 0.1 & 0.007 \\
SFS & 6.71 & 23.8 & 32.7 & 11.3 & 2.26 & 1.01 & 1.02 & 0.4 & 0.03 \\
FRP & 4.13 & 14.6 & 20.1 & 7. & 1.39 & 0.62 & 0.63 & 0.25 & 0.02 \\
\hline Total & 16.2 & 62.6 & 84.6 & 27. & 4.98 & 2.45 & 2.67 & 1.21 & 0.14 \\
\hline
\end{tabular}

Table 9. Uniform 50-year gamma-ray dose in rem as a function of the 9 latitude bands for the weapons and nuclear power facilities. These values do not take into account any weathering, sheltering or rainfall factors. "Hot-spots" due to rainfall could inerease these values by factors of $10-50$ [10]. 


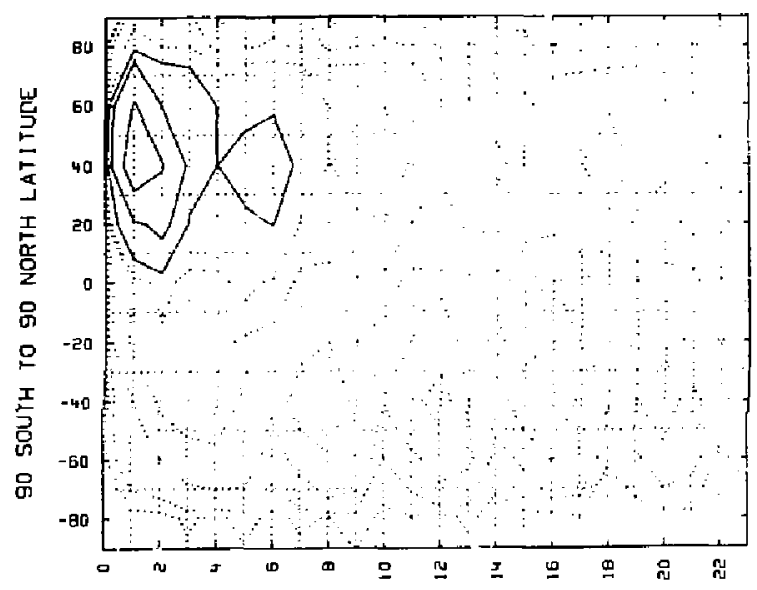

Time in Quarters

Figure 9. Contour plots of the fractional deposition due to the Strategic Exchange. The abseissa is the time in quarters and the ordinate runs from the South Pole $(-90)$ to the North Pole $(+90)$. The highest solid contour has value 0.1 , the next 0.03 , then 0.01 . The dotted contours are $0.03,0.001,0.003,0.0001$ and 0.0003 .

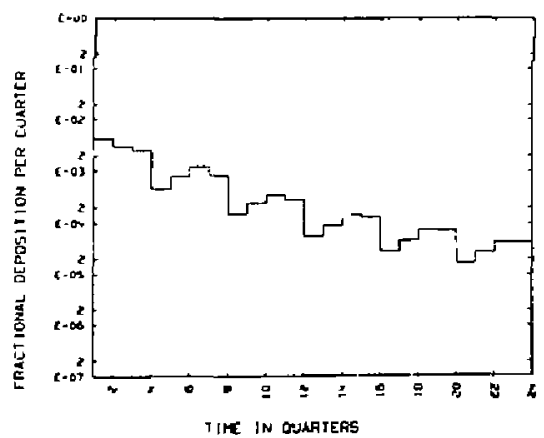

FGure 10a. 70-90N

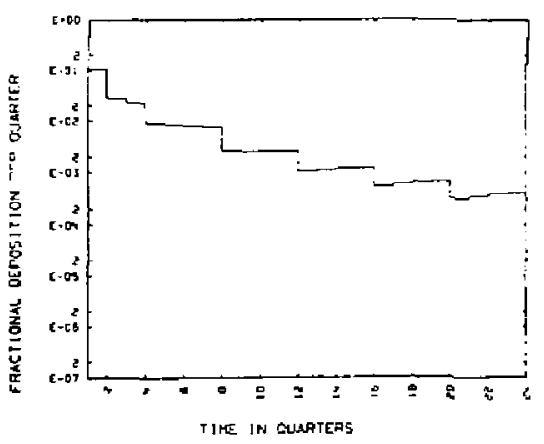

Figure 10b. $50-70 \mathrm{~N}$ 


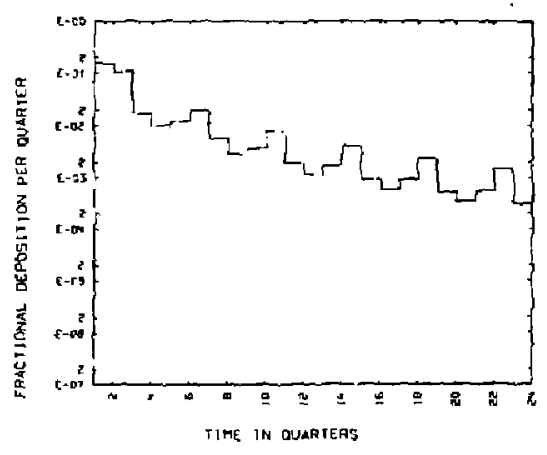

Eigure 10e, 30-50N

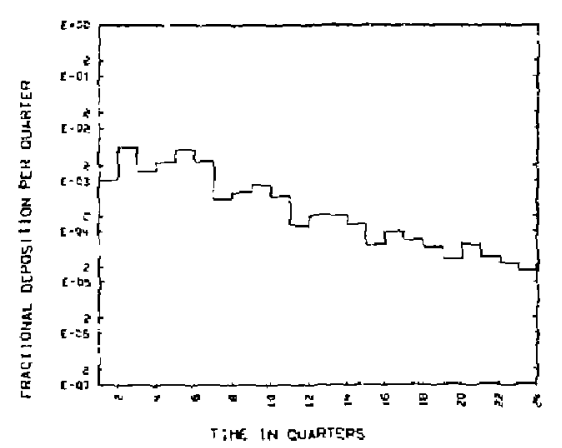

Figure 1 De. IOS-10N

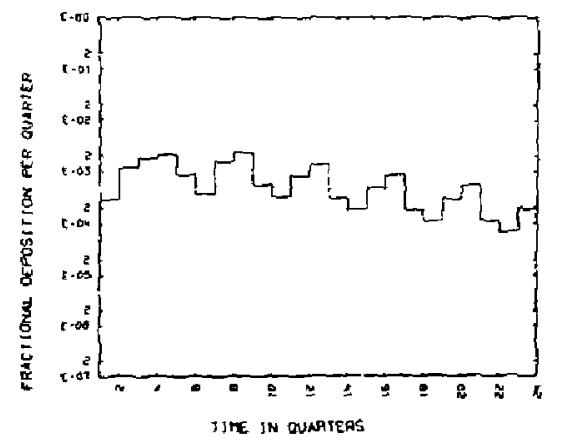

Figure 10g. 30-50S

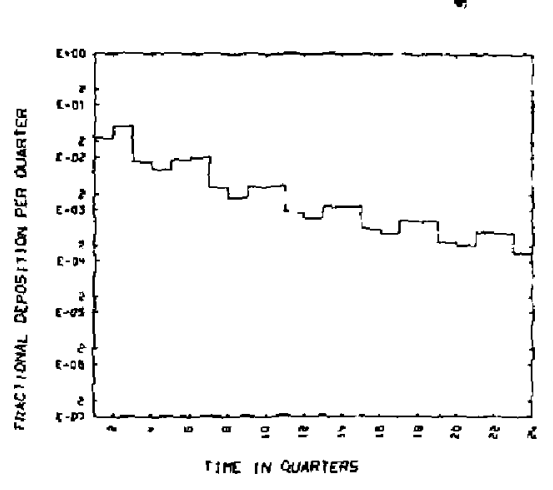

Figure 10d. $10-30 \mathrm{~N}$

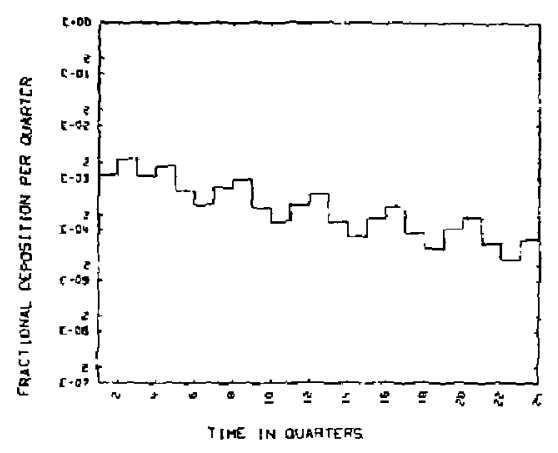

- igure 10f. 10-50S

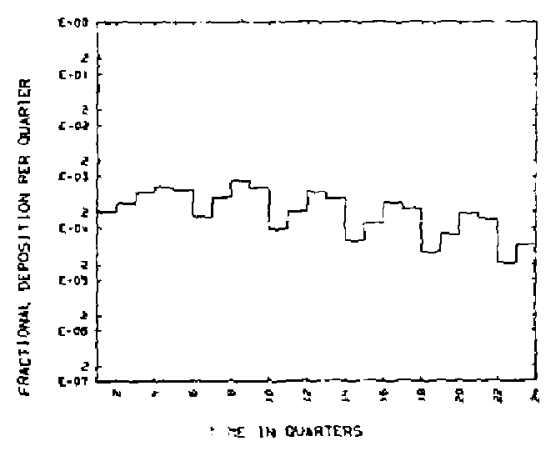

Figure 10h. 50-70s 


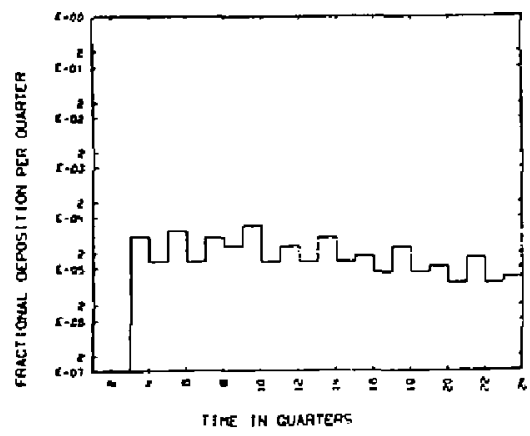

Figure 10i. 70-90S

Figure 10. Fractional depositions as a function of quarters after injection for each of the 20-degree latitude bands.

Pigure 11 is a contour plot of the accumulated dose for only the weapons. Figure 12 includes the $110 \mathrm{GW}(e)$ nuclear power industry. One observes the highest dose contour at about $40 \mathrm{~N}$. The highest contour for only the weepons appears early in time whereas the highest contour when the nuclear power facilities are included does not appear until about 40 guarters. This effect is due to the rapid decay of weapons fission products compared to the relatively slow decay of the fission products in the 10-year spent fuel waste storage and the federal nuelear waste reprocessing plant. Figure 13 shows the accumulated gamma dose as a function of time for each of the latitude bands. The separation of the two curves at late time also shows the difference of decay rates.

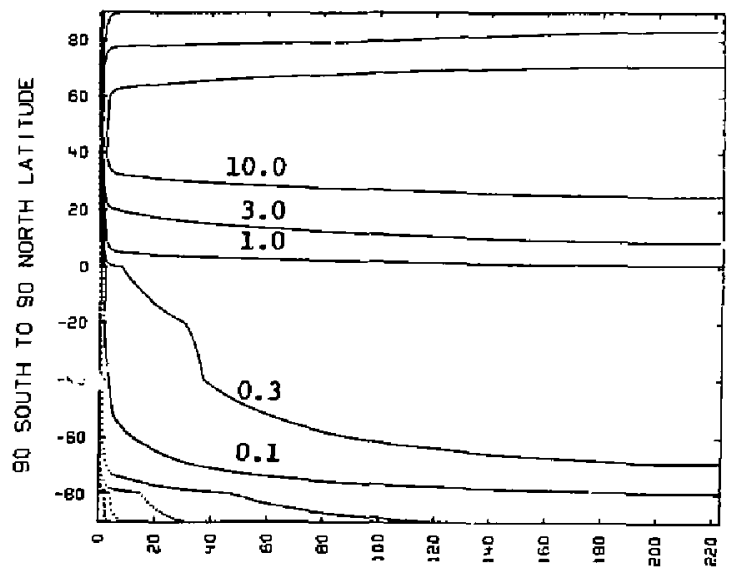

Time in Quarters

Figure 11. Contour plot of the accumulated gamma dose for only the weapons of the Strategic Exchange. The abseisse is the time in quarters and the ordinate runs from the South Pole $(-90)$ to the North Pole $(+90)$. 


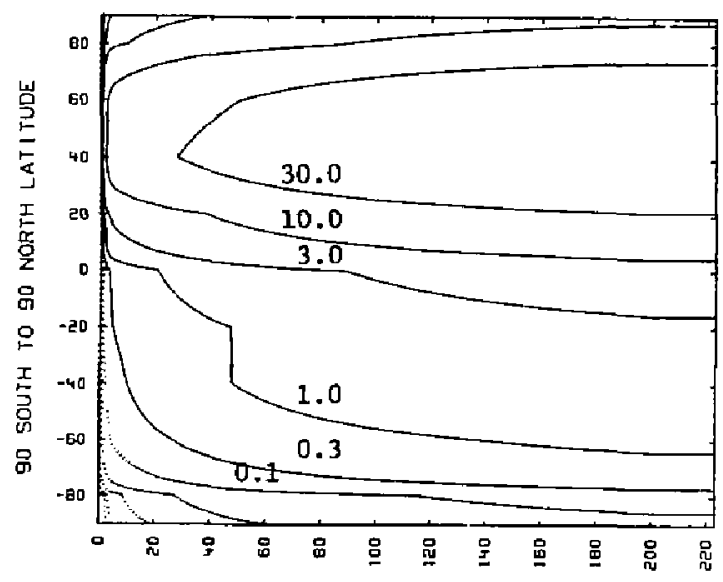

Time in Querters

Figure 12. Contour plot of the accumulated gamma dose due to the Strategic Exchenge augmented with a $100 \mathrm{GW}(\mathrm{e})$ nuclear power industry. The abscissa is the time in quarters and the ordinate runs from the South Pole $(-90)$ to the North Pole $(+90)$.

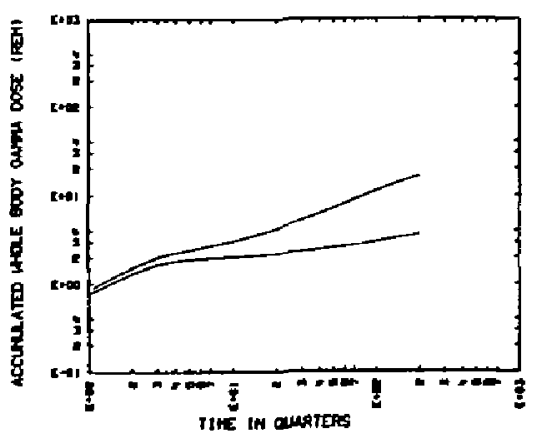

Figure 13a. 70-90N

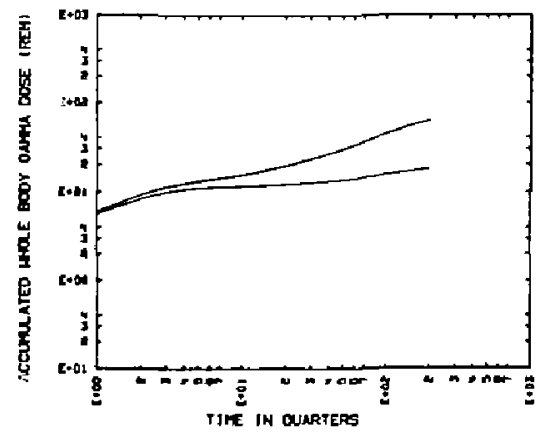

Figure 13b. 50-70N 


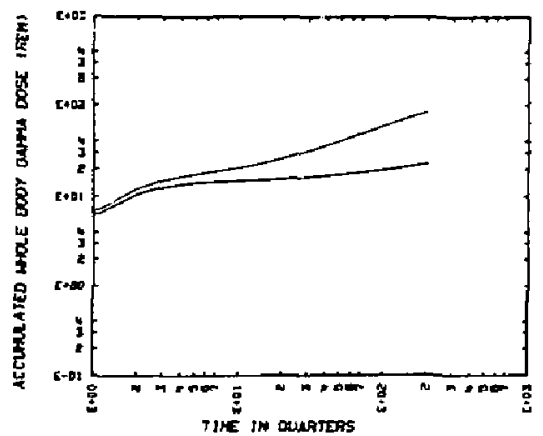

Figure 13c. $30-50 \mathrm{~N}$

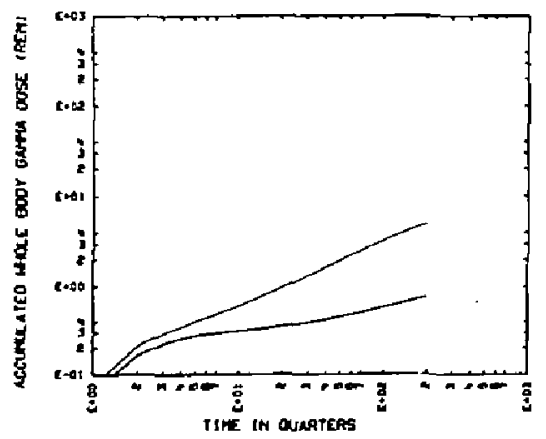

Figure 13 e. 10S-10N

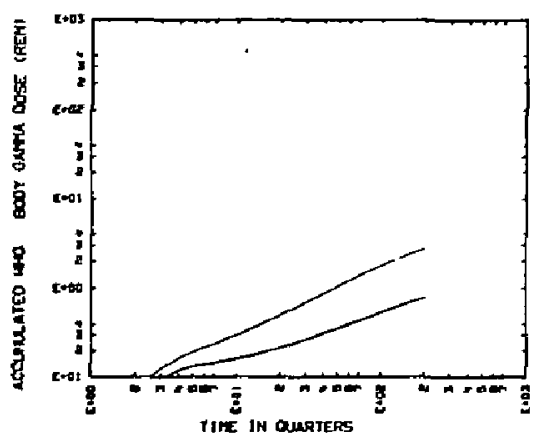

Figure 13g. 30-50s

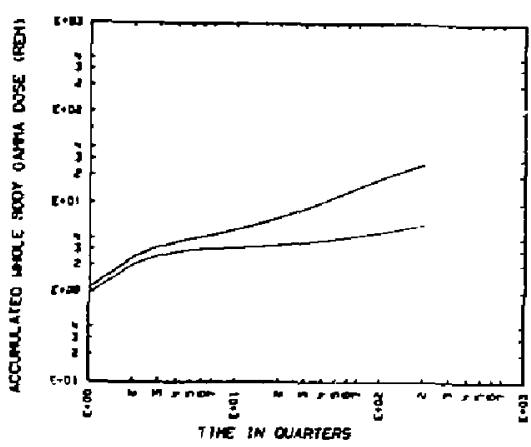

Figure 13d. 10-30N

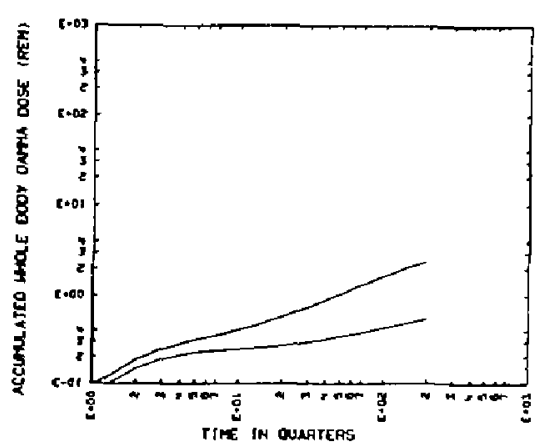

Figure 13f. 10-30S

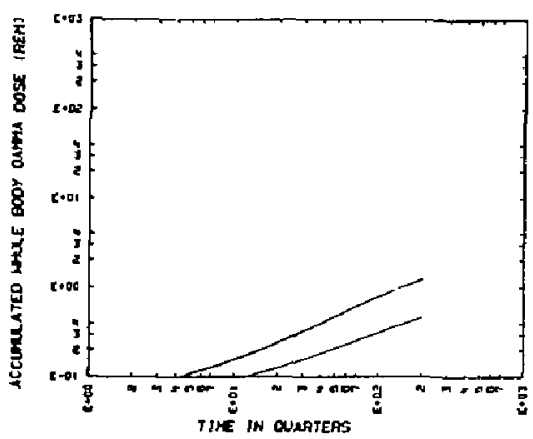

Figure 13h. 50-70s 


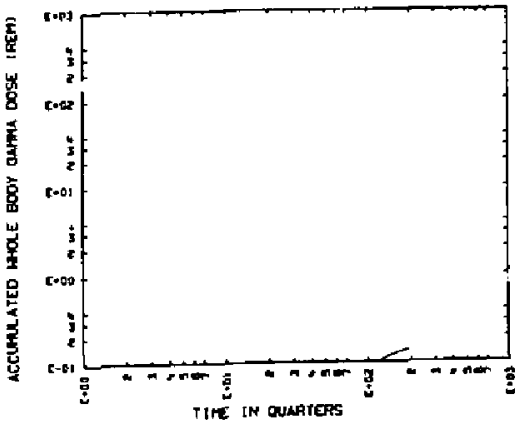

Figure 13i. 70-90s.

Figure 13. Accumulated 50-year gamma dose 'as a funetion of quarters far each of the 20-degree latitude bends. The higher value is for the weapons augmented by $100 \mathrm{GW}(\mathrm{e})$ nuclear power industry.

The dose using the weathering, rainfall, and roughness factor has been computed for five specific locrtions with results as shown in Table 10.

\begin{tabular}{lccccc}
\hline & London & Montreal & Lisbon & Tolkyo & Sydney \\
\hline & & & & & \\
Latitude & $51.48 \mathrm{~N}$ & $45.57 \mathrm{~N}$ & $38.72 \mathrm{~N}$ & $35.68 \mathrm{~N}$ & $33.87 \mathrm{~s}$ \\
Local Average Rainfall $(\mathrm{mm})$ & 583 & 970 & 701 & 1560 & 1200 \\
Letitude Average Rainfall $(\mathrm{mm})$ & 819 & 910 & 788 & 733 & 905 \\
50-yr dose (rem) & 17.8 & 22.3 & 221 & 27. & 0.6
\end{tabular}

Table I $\mathrm{n}$ Gamma dose in rem for the Strategic Exchange with $100 \mathrm{GW}(\mathrm{e})$ nuelear power facilities at five specific locations.

Figure 14 shows the time dependent accumulation of gamma dose at each of the specific locations with and without the nuclear power facilities augmentation. The effest of weathering on reduction of aceumulated dose ean be a signifieant factor. For example, at Tokyo, the interpolated uniform dose would be about 72 rem. With ratifall, penetration, run-off and weatherirg, the dose is 27 rem after 50 years of aecumulation.

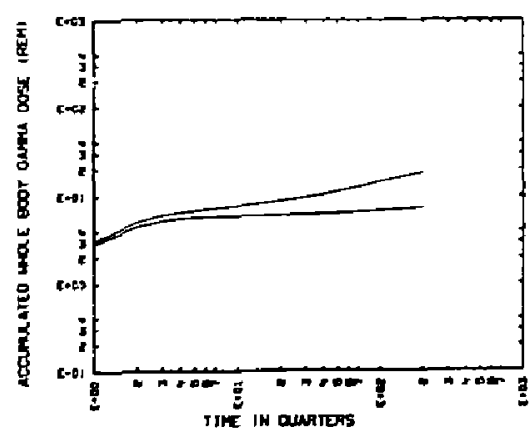

F fgure 14a. London

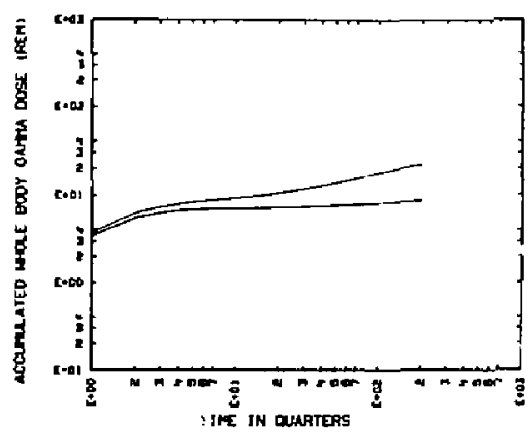

Figure 14b. Montreal 


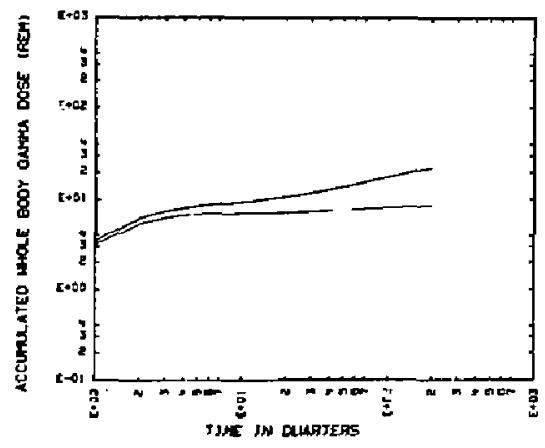

Fiģure 14c. Lisbon

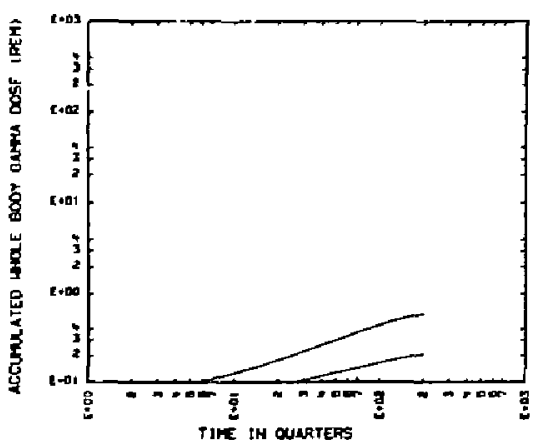

Figure 14e. Sydney

Figure 14. Time accumulated gamma dose using local rainfall, weathering, run-off and $a$ roughness factor for the indicated locations.

\section{DISCUSSION AND CONCLUSIONS}

The GLCDEP2 computer model is capable of estimating the surface rerosition of "worldwide" radioactivity and the gamma-ray dose to man from the intermediate and long-tern fallout. Code generated predictions of the gamma dose due to the atmospheric tests of 1951-1962 agree well with the measurements at two specific locations.

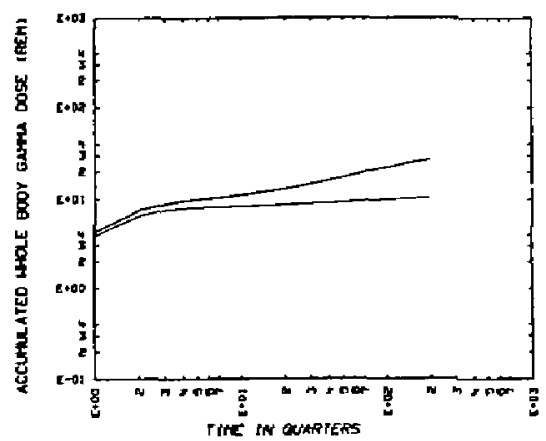

Figure 14d. Tokyo 
Although the injection and long term deposition models of GLODEP2 are only slight modifieations of those proposed by Peterson [5] GLOVEP2 has original modeling in tropospherie deposition, injection and depnsition from nuelear installations, ganma dose, weathering, penetration, runoff, and roughness.

The intermediate term deposition in the Gaussian formulation for fallout from the troposphere appears to be reasonable, in view of the measurements reported by Maehta [14] However, uncertainties exist in terms of the time for completion of f allout as well as the shape of the Gaussian. Further, cross-hemispheric flow is slow, somewhat seasonal and usually occurs in preferred areas. Additional research and modeling is warranted in this area if significant portions of the injections are in the equatorial tropospheric compartment.

The models employed for dose calculations also have margins of uncertainty. The exact values of the dose-area-integrals are unknown for weapons where tests have been conducted. The values for the particular nuelear power facilities have never been tested against an experiment where the facility has been vaporized by a nuelear weapon.

In our models for dose calculations at specifie locations we int roduce even more margins of uncertainty. The terrain roughness factor of 0.7 may be reasonable for moderately rough terrain. Further research might produce substantiai changes in this factor for other regions and certainly for the complexity of urben areas.

The data we have used seem to indicate that the use of the local rain rate/average rain rate to the $3 / 5$ ths power may be reasonable; however, we have not used any measurements from areas with little preeipitatic 1 , nor have we used measurements from arees with tropical or monsoon types of weather.

The penetration-runoff model is based on measurements of ${ }^{137} \mathrm{Cs}$ and applied to the entire inventory of radionuclides. ". is well known that the solubility and mobility of other nuclides may vary over wide ranges, hence another area of uncertainty. 
Peterson [5] has stated that his "model is based paimarily on injection-deposition experience gained from the U.S. and U.S.S.R. nuclear tests in 1958. Use of the fechnigue to estimate 95r deposition from the 1961-62 tests shows the predictions are usually within a factor of two of the observed deposition. He further asserts that

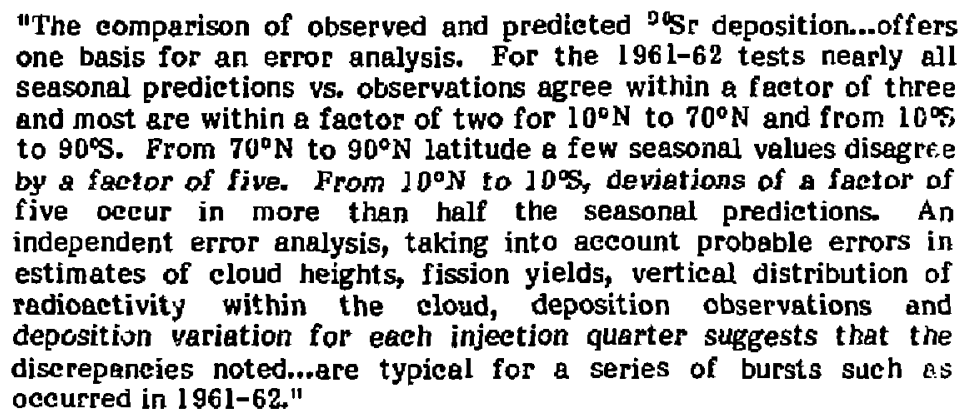

Peterson [5] has also noted the following limitations of the methodology:

"Because of time and space variations of deposition from individual detonations, deposition predietions for single devonations may be grossly in error. Predictions are for $20^{\circ}$ latitude bands and 3-mont h seasons. Application of these average values to specific locations or sharter times should be made with eaution since variations of about en order of magnitude have been observed in 3-mortic deposition values within "wet' regions of the United States."

In GLODEP2 we have ineluded models to account for the differences bet ween the "uniforn" dose of the $20^{\circ}$ latitude bands and that duse at specific locations. Our penetration, run-off and rainfall models are derived primarily from measurements at Grove. However, large partions of these data were obtained from independent, controlled experiments. Further, the injection and deposition models are independert of these data. Thus the computations at Grove and Chibe provide "cade validation.' We have noted that the values computed for chibe use the GLODEP2 models directly with no fitting of parameters to the measurements reported there. 
In view of the uncertainties esscelated with the entire suite of GLODEP2 models, the agreement with measurements at the two loeations selected may be somewhat fortuitous, but the predictions do lend a measure of eredibility to the GLODEP2 model.

It is important to bear in mind that the GLODEP2 deposition models are empirically derived. If a large nuclear exchange were to occur and $\underline{i f}$, in fact, the exchange ca'ssed a "nuclear winter" it is probable "that the current empirical circ:lation and meteorological models would no longer be valid.

Inasmuch as we do not expect to obtain a great deal of new experimental daca, sensitiv. : and uncertainty analyses with the present model are suggested as areas of further research. Future reviews of the existing data coupled with such analyses might lead to some revisions of the models and, more importantly, should lead to predictions that are certainly within acceptable error bounds.

It should be poirted out that even though Peterson [5] suggests a "mirror-image" approach for detonations in the Southern Hemisphere, this technique has not been implemented in the current GLODEP2. Presently we assume all detonations are in the Northern Hemisphere. However, the extension should be a simple programming task.

\section{REFERENCES}

[1] Smyth, H. D., Method of Assembly, 12, 19, Atomic Energy for Military Purposes, Princeton University Press, $\{1840\}$, p 212.

[2] AMP'O, A Journal of the Human Enviconment, vol. XI, Number 2-3 (1982).

[3] Neir, A. O. C., Chairman, Committee to Study the Long-Term Worldwide Effeets of Multiple Nuclear-Weapons Detonations, National Academy of Sciences, (Aug. 1975).

[4] Chester, C. V., and R. O. Chester, Civil Defense Implications of the U.S. Nuclear Power Industry During a Large Nuclear War in the Year 2000, Nuelear Technology, vol 31, (Dec. 1976) pp 326-338. 
[5] Peterson, K. R., An Empirical Model for Estimating Worldwide Deposition from Atmospherie Nuclear Detonations, Health Phys, Pergamon Press, vol 19, (1970), pp 357-378.

[6] Gale, H. J., D. L. O. Humphreys and E. M. R. Fisher, Weathering of Caesium-i 37 in Soil, Nature, No. 4916, (Jan. 18, 1964), pp 257-261.

[7] Lowder, W. M., H. L. Beck and W. J. Condon, Dosimetric Investigations of Environmental Gemma Rediation from Deposited Fission Produets, Proceedings of the Second Conference on Radioactive Fallout from Nuclear Weapons Tests, U.S.A.E.C., (Nov. 1965).

[8] List, R., L. Salter and K. Telegadas, Tellus 18, 345 (1966).

[9] Ferber, G., Kadiogctive Fallout from Nuclear Weapons Tests, U.S.A.E.C., Oak Kidge, Tenn. (1965), pp. 629-645.

[10] U.S. Weather Bureau, U.S.A.E.C. Rept HASL-142 (1964), pp. 218-239.

[11] Seitz, H., et al, Final Report on Project Streak: Numerical models of transport, diffusion and falfout of stratospheric radiogctive material, Re. N YO-3654-4, Atomic Energy Comm., Washington, D.C., (May 1968).

[12] Telegadas, K., Estimation of Maximum Credible Atmospheric Radioactivity Concentrations and Dose Rates from Nuclear Tests, Atmos. Environ. I3, 327, 1979.

[13] Bauer, E., A Catalog of Perturbing Influences on Stratospheric Ozone, 1955-1 975, J. of Geophysicu Research, vol 84, No c Il, November 20, 1979, PP $69 \div 9-6940$.

[14] Eisenbud, M., Environmental Radicactivity, 2nd Ed., Academic Press, New York, (1973), p 355.

[15] Glasstone, S., and P. J. Dolan, The Effects of Nuclear Weapons, 3rd Edition, U.S.D.O.D. and U.S.D.O.E. (1977).

[16] Lamb, H. H., Climate: Present, Past and Future, Vol 1, Methuen \& Co., LTD, London (1977), p 370 .

[17] Harvey, T. F., and L. L. Edwards, Long-Range Nuclear War Fallout Doses Near Selected Non-Combatant Country Cities, UCRL draft report (1983).

[18] Knox, J. H., Global Scale Deposition of Radioactivity from a Large Scale Exchange, Lawrence Livermore National Laboratory Report UCRL-89907 (preprint), (Oet. 1983).

[19] Ionizing Radiation: Sources and Biological Effects, United Nations Scientific Committee on the Effects of Atomic Radjation, 1982 Report to the General Assembly, with annexes, United Nations, New York, (1982). 
[20] Gibson, J. A. B., J. E. Richards and J. Docherty, Nuclear Radiation in the Environment-Beta and Gamme-Ray Dose Rates and Air Ionization from 1951 to 1968, J. of Atmospheric and Terrestrial Physics, 31, (1969), pp L 183-1196.

[21] Yamasaki, F., M. Okano, T. Nagahana and H. Watanabe, External Doses of Rediation from Fallout in Tokyo and its Vicinity, J. of Radiation Research, (1964), PP 113-115.

[22] National Institute of Radiological Sciences, Chiba, Jepan. External Doses of Radiation from Fallout, Radioactivity Survey Data in Japan, No. 15, (1967), Pp 8-9.

[23] National Institute of Hadiological Seienees, Chiba, Japan, External Doses of Radiation from Fallout in Tokyo and its Vicinity, Radioactivty Survey Data in Japan, No. 19, (1 968), pp 10-11.

[24] lonizing Radiation: Levels and Effects, Vol. l, Levels, United Nationals Seientific Committee on the Effects of Atomic Radiation, New York, (1972), p 56.

[25] Cotter, D. R., J. H. Hansen, and K. MeConnell, The Nuelear "Balance" in Europe: Status, Trends, Implications, United States Strategic Institute, USSI Report 83-1, 1983).

[26] Walton, J. J. and M. C. MacCracken, Preliminary Report on the Global Transport Model GRANTOUR, Lawrence Livermore National I.sioratory, Li vermore, CA., UCID-1 9985 (1984). 


\section{APPENDIX A}

The following data tables have been taken from the work of Peterson (1970). In the following we have converted most numbers to pure fractions. 


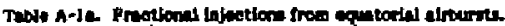
(Fiton ylaberotel ylab)

\begin{tabular}{|c|c|c|c|c|c|c|c|c|c|c|c|c|c|c|c|c|}
\hline & D.ES & 0.07 & (2) & 0.2 & a.s & 0.3 & $\begin{array}{l}\text { Tote } \\
\text { a.7 }\end{array}$ & od into & 3 & 3 & 5 & 7 & 10 & 20 & J0 & 50 \\
\hline 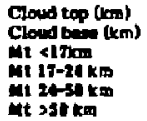 & $\begin{array}{l}17.1 \\
10.0 \\
0.049 \\
0.001 \\
0 \\
0\end{array}$ & $\begin{array}{l}17.4 \\
10.0 \\
0.068 \\
0.002 \\
0\end{array}$ & $\begin{array}{l}17.0 \\
10.4 \\
0.005 \\
0.005 \\
0 \\
0\end{array}$ & $\begin{array}{c}11.0 \\
11.0 \\
0.11 \\
0.01 \\
0 \\
0\end{array}$ & $\begin{array}{l}18.5 \\
11.2 \\
0.8 \\
0.4 \\
0\end{array}$ & $\begin{array}{c}140 \\
11.0 \\
0 \\
0 \\
0\end{array}$ & $\begin{array}{l}14.1 \\
16.1 \\
45 \\
6 \\
6\end{array}$ & $\begin{array}{c}14.4 \\
1 \text { tet } \\
0.45 \\
0\end{array}$ & $\begin{array}{l}220 \\
140 \\
0.95 \\
1.45 \\
0\end{array}$ & $\begin{array}{l}23.5 \\
14.0 \\
0.24 \\
0.10 \\
0\end{array}$ & 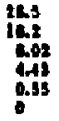 & $\begin{array}{l}24.4 \\
17.4 \\
4 \\
\text { inet } \\
0\end{array}$ & $\begin{array}{l}30.5 \\
\operatorname{lng} \\
5.25 \\
0\end{array}$ & $\begin{array}{c}25.4 \\
120 \\
0 \\
200 \\
0\end{array}$ & $\begin{array}{c}32.4 \\
207 \\
0 \\
27.1 \\
0\end{array}$ & $\begin{array}{c}12.7 \\
81.3 \\
0 \\
0.5 \\
0.5 \\
0\end{array}$ \\
\hline
\end{tabular}

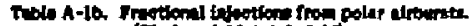

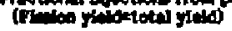

\begin{tabular}{|c|c|c|c|c|c|c|c|c|c|c|c|c|c|c|c|c|}
\hline & 0.03 & a.ts & 0.07 & 41 & ex & es: & .5 & Tothl gited (ntod & 2 & 3 & 5 & 1 & 10 & 10 & 90 & 50 \\
\hline 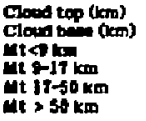 & $\begin{array}{l}10.1 \\
4.0 \\
0.020 \\
0.001 \\
0 \\
0\end{array}$ & $\begin{array}{l}10.4 \\
4.4 \\
0.059 \\
0.045 \\
0 \\
0\end{array}$ & $\begin{array}{l}10.7 \\
4.5 \\
0.41 \\
0 \\
0\end{array}$ & $\begin{array}{l}11.0 \\
40 \\
40 \\
0.02 \\
0\end{array}$ & $\begin{array}{l}\text { 11.4 } \\
5.5 \\
0.14 \\
0 \\
0\end{array}$ & 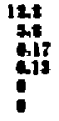 & $\begin{array}{l}124 \\
610 \\
610 \\
0\end{array}$ & 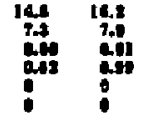 & $\begin{array}{l}14.5 \\
6.5 \\
1.80 \\
04\end{array}$ & $\begin{array}{l}12.0 \\
11.04 \\
1.45 \\
1.55\end{array}$ & $\begin{array}{l}\text { 25.3 } \\
1+1 \\
0 \\
0.93 \\
0 \\
0\end{array}$ & 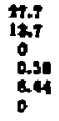 & $\begin{array}{c}90.3 \\
15,5 \\
0 \\
0.06 \\
0.04 \\
0\end{array}$ & $\begin{array}{c}145 \\
0 \\
0 \\
0 \\
0\end{array}$ & $\begin{array}{c}5+1 \\
19.5 \\
0 \\
000 \\
0\end{array}$ & $\begin{array}{c}12.7 \\
90.7 \\
0 \\
0 \\
50.0 \\
0\end{array}$ \\
\hline
\end{tabular}


Table A-2a. Fractional deposition (x 100) for injection of debris during Dec-Feb into the Lower Equatorial Stratosphere (17-24 km).

\begin{tabular}{|c|c|c|c|c|c|c|c|c|c|c|}
\hline \multirow[b]{2}{*}{ Latitude } & \multicolumn{4}{|c|}{ lst yr } & \multicolumn{4}{|c|}{ 2nd yr } & \multicolumn{2}{|c|}{ 3rd yr } \\
\hline & $\begin{array}{r}\text { Dec- } \\
\text { Feb }\end{array}$ & $\begin{array}{c}\text { Mar- } \\
\text { May }\end{array}$ & $\begin{array}{l}\text { June- } \\
\text { Aurg }\end{array}$ & $\begin{array}{c}\text { Sept- } \\
\text { Nov }\end{array}$ & $\begin{array}{c}\text { Dec- } \\
\text { Feb }\end{array}$ & $\begin{array}{c}\text { Mar- } \\
\text { May }\end{array}$ & $\begin{array}{l}\text { June- } \\
\text { Aug }\end{array}$ & $\begin{array}{r}\text { Sept- } \\
\text { Nov }\end{array}$ & $\begin{array}{c}\text { Dec- } \\
\text { Feb }\end{array}$ & Mar- \\
\hline $\begin{array}{l}50-70 N \\
30-50 N \\
10-30 N \\
10 S-10 N \\
10-30 S \\
30-50 S \\
30-7 C S \\
70-90 S\end{array}$ & $\begin{array}{r}.04 \\
.52 \\
1.12 \\
1.44 \\
1.40 \\
.56 \\
.78 \\
.40 \\
0\end{array}$ & $\begin{array}{l}.41 \\
2.60 \\
9.89 \\
2.39 \\
3.07 \\
3.28 \\
2.46 \\
1.24\end{array}$ & $\begin{array}{l}.12 \\
1.39 \\
3.03 \\
3.10 \\
2.39 \\
2.58 \\
1.93 \\
.96 \\
0\end{array}$ & $\begin{array}{r}.06 \\
.66 \\
1.42 \\
.74 \\
2.52 \\
.99 \\
213 \\
1.06 \\
.01\end{array}$ & $\begin{array}{r}.06 \\
.68 \\
1.46 \\
1.05 \\
.66 \\
.33 \\
1.42 \\
.71 \\
0\end{array}$ & $\begin{array}{l}.1 \\
1.6 \\
3.4 \\
1.3 \\
1.8 \\
1.0 \\
.6 \\
.3 \\
0\end{array}$ & $\begin{array}{r}.0 \\
.4 \\
1.0 \\
1.0 \\
.8 \\
.9 \\
.6 \\
.3\end{array}$ & $\begin{array}{l}.0 \\
.2 \\
.5 \\
.2 \\
.8 \\
.3 \\
.7 \\
.3 \\
0\end{array}$ & $\begin{array}{l}.0 \\
.2 \\
.5 \\
.3 \\
.2 \\
.1 \\
.5 \\
.2 \\
0\end{array}$ & $\begin{array}{r}.05 \\
.56 \\
1.21 \\
.49 \\
.65 \\
.38 \\
.23 \\
.12 \\
0\end{array}$ \\
\hline
\end{tabular}

Table A-2b. Fractional ceposition (x 100) for injection of debris during Mar-May into the Lower Equatorial Stratosphore $(17-24 \mathrm{~km})$.

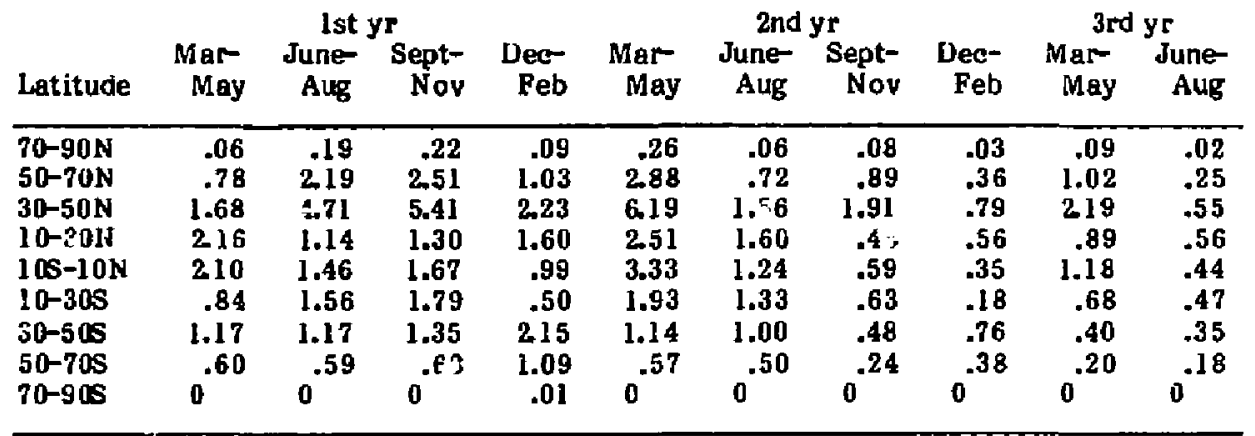


Table A-ze. Fractional deposition ( $x$ 100) for injection of debris during Jun-Aug into the Lower Equatorial Stratosphere $(17-24 \mathrm{~km})$.

\begin{tabular}{|c|c|c|c|c|c|c|c|c|c|c|}
\hline \multirow[b]{2}{*}{ Latitude } & \multicolumn{4}{|c|}{ lst yr } & \multicolumn{4}{|c|}{ 2nd yr } & \multicolumn{2}{|c|}{ 3rd yr } \\
\hline & $\begin{array}{l}\text { June- } \\
\text { Aug }\end{array}$ & $\begin{array}{l}\text { Supt- } \\
\text { Nov }\end{array}$ & $\begin{array}{c}\text { Dec- } \\
\text { Feb }\end{array}$ & $\begin{array}{c}\text { Mar- } \\
\text { May }\end{array}$ & $\begin{array}{c}\text { June- } \\
\text { Aug }\end{array}$ & $\begin{array}{l}\text { Sept- } \\
\text { Nov }\end{array}$ & $\begin{array}{l}\text { Dec- } \\
\text { Peb }\end{array}$ & $\underset{\text { May }}{\text { Mar- }}$ & $\begin{array}{c}\text { June- } \\
\text { Aug }\end{array}$ & $\begin{array}{l}\text { Sept- } \\
\text { Nov }\end{array}$ \\
\hline $\begin{array}{l}70-90 \mathrm{~N} \\
50-70 \mathrm{~N} \\
30-50 \mathrm{~N} \\
10-30 \mathrm{~N} \\
105-10 \mathrm{~N} \\
10-30 \mathrm{~S} \\
30-50 \mathrm{~S} \\
50-70 \mathrm{~S} \\
70-90 \mathrm{~S}\end{array}$ & $\begin{array}{l}.02 \\
.26 \\
.56 \\
.72 \\
.70 \\
.28 \\
.39 \\
.20 \\
0\end{array}$ & $\begin{array}{l}.21 \\
2.37 \\
5.10 \\
1.23 \\
1.58 \\
1.69 \\
1.27 \\
.64 \\
0\end{array}$ & $\begin{array}{r}.15 \\
1.64 \\
3.54 \\
2.54 \\
1.57 \\
.79 \\
3.42 \\
1.73 \\
.0 \%\end{array}$ & $\begin{array}{l}.32 \\
3.48 \\
7.48 \\
3.04 \\
4.03 \\
2.33 \\
1.59 \\
.69 \\
0\end{array}$ & $\begin{array}{r}.07 \\
.81 \\
1.76 \\
1.80 \\
1.39 \\
1.50 \\
1.12 \\
.56\end{array}$ & $\begin{array}{r}.02 \\
.56 \\
1.21 \\
.63 \\
2.15 \\
.85 \\
1.82 \\
.91 \\
.01\end{array}$ & $\begin{array}{l}.05 \\
.58 \\
1.25 \\
.90 \\
.56 \\
.28 \\
1.21 \\
.61 \\
0 .\end{array}$ & $\begin{array}{l}.11 \\
1.23 \\
2.64 \\
1.07 \\
1.42 \\
.82 \\
.49 \\
.25 \\
0^{3}\end{array}$ & $\begin{array}{l}.03 \\
.29 \\
.62 \\
.64 \\
.49 \\
.53 \\
.40 \\
.20 \\
0\end{array}$ & $\begin{array}{l}.02 \\
.20 \\
.43 \\
.22 \\
.76 \\
.30 \\
.64 \\
.32 \\
0\end{array}$ \\
\hline
\end{tabular}

Table A-2d. Fractional deposition ( $x$ 100) for injection of debris during Sep-Nov into the Lower Equatorial Stratosphere (17-24 km).

\begin{tabular}{|c|c|c|c|c|c|c|c|c|c|c|}
\hline \multirow[b]{2}{*}{ Latitude } & \multicolumn{4}{|c|}{ lst yr } & \multicolumn{4}{|c|}{ 2nd yr } & \multicolumn{2}{|c|}{$3 r d y r$} \\
\hline & $\begin{array}{l}\text { Sept- } \\
\text { Nov }\end{array}$ & $\begin{array}{c}\text { Dee- } \\
\text { Feb }\end{array}$ & $\begin{array}{c}\text { Mar } \\
\text { May }\end{array}$ & $\begin{array}{l}\text { June- } \\
\text { Aug }\end{array}$ & $\begin{array}{r}\text { Sept- } \\
\text { Nov }\end{array}$ & $\begin{array}{c}\text { Dec- } \\
\text { Feb }\end{array}$ & $\begin{array}{c}\text { Mar- } \\
\text { May }\end{array}$ & $\begin{array}{l}\text { June- } \\
\text { Aug }\end{array}$ & $\begin{array}{c}\text { Sept- } \\
\text { Nov }\end{array}$ & $\begin{array}{l}\text { Dec- } \\
\text { Feb }\end{array}$ \\
\hline $\begin{array}{l}70-90 \mathrm{~N} \\
50-70 \mathrm{~N} \\
30-50 \mathrm{~N} \\
10-30 \mathrm{~N} \\
105-10 \mathrm{~N} \\
10-30 \mathrm{~S} \\
30-5 \mathrm{WS} \\
50-70 \mathrm{~S} \\
70-90 \mathrm{~S}\end{array}$ & $\begin{array}{l}.03 \\
.39 \\
.84 \\
1.08 \\
1.05 \\
.42 \\
.59 \\
.30 \\
0\end{array}$ & $\begin{array}{l}.22 \\
2.51 \\
5.41 \\
1.30 \\
1.67 \\
1.79 \\
1.35 \\
.68\end{array}$ & $\begin{array}{l}.37 \\
4.04 \\
8.68 \\
3.53 \\
4.67 \\
2.70 \\
1.60 \\
.80 \\
0\end{array}$ & $\begin{array}{l}.09 \\
1.04 \\
2.25 \\
2.30 \\
1.78 \\
1.92 \\
1.43 \\
.72 \\
0\end{array}$ & $\begin{array}{r}.05 \\
.60 \\
1.31 \\
.68 \\
2.32 \\
.92 \\
1.97 \\
.98 \\
.01\end{array}$ & $\begin{array}{r}.05 \\
.63 \\
1.35 \\
.97 \\
.60 \\
.30 \\
1.31 \\
.66\end{array}$ & $\begin{array}{l}.13 \\
1.43 \\
3.06 \\
1.25 \\
1.65 \\
.95 \\
.55 \\
.28\end{array}$ & $\begin{array}{l}.03 \\
.37 \\
.79 \\
.81 \\
.63 \\
.68 \\
.50 \\
.25\end{array}$ & $\begin{array}{l}.02 \\
.21 \\
.46 \\
.24 \\
.82 \\
.32 \\
.70 \\
.35\end{array}$ & $\begin{array}{l}.02 \\
.22 \\
.48 \\
.34 \\
.21 \\
.11 \\
.46 \\
.23\end{array}$ \\
\hline
\end{tabular}


Table A-3a. Fractional deposition (x 10,0) for injection of debris during Dec-Feb into the Upper Equatorlal Stratosphere (24-50 k,n).

\begin{tabular}{|c|c|c|c|c|c|c|c|c|c|c|c|c|c|}
\hline Latitude & $\begin{array}{c}\text { Dec- } \\
\text { Feb }\end{array}$ & $\begin{array}{c}\text { lst } \\
\text { Mar- } \\
\text { May }\end{array}$ & $\begin{array}{l}\text { June- } \\
\text { Aug }\end{array}$ & $\begin{array}{l}\text { Sept- } \\
\text { Nov }\end{array}$ & $\begin{array}{r}\text { Dec- } \\
\text { Feb }\end{array}$ & $\begin{array}{c}\text { 2nd } \\
\text { Mar- } \\
\text { May }\end{array}$ & $\begin{array}{l}\text { June- } \\
\text { Aug }\end{array}$ & $\begin{array}{l}\text { Sept- } \\
\text { Nov }\end{array}$ & $\begin{array}{r}\text { Dec- } \\
\text { Feb }\end{array}$ & $\begin{array}{c}\text { 3rd } \\
\text { Mar- } \\
\text { May }\end{array}$ & $\begin{array}{l}\text { yi: } \\
\text { June- } \\
\text { Aug }\end{array}$ & $\begin{array}{c}\text { Sept- } \\
\text { Nov }\end{array}$ & $\begin{array}{l}\text { 4th yr } \\
\text { Dec- } \\
\text { Feb }\end{array}$ \\
\hline $\begin{array}{l}70-90 \mathrm{~N} \\
50-70 \mathrm{~N} \\
30-50 \mathrm{~N} \\
10-30 \mathrm{~N} \\
10 \mathrm{~S}-10 \mathrm{~N} \\
10-30 \mathrm{~S} \\
30-50 \mathrm{~S} \\
50-70 \mathrm{~S} \\
70-90 \mathrm{~S}\end{array}$ & $\begin{array}{l}0 \\
0 \\
0 \\
0 \\
0 \\
0 \\
0 \\
0 \\
0\end{array}$ & $\begin{array}{l}.04 \\
.46 \\
.99 \\
.24 \\
.27 \\
.11 \\
.45 \\
.21 \\
.02\end{array}$ & $\begin{array}{l}.03 \\
.33 \\
.72 \\
.59 \\
.44 \\
.53 \\
.74 \\
.34 \\
.03\end{array}$ & $\begin{array}{r}.03 \\
.28 \\
.60 \\
.32 \\
.47 \\
1.14 \\
2.80 \\
1.30 \\
.12\end{array}$ & $\begin{array}{l}.04 \\
.46 \\
.98 \\
.71 \\
.48 \\
.67 \\
.74 \\
.48 \\
.04\end{array}$ & $\begin{array}{r}.14 \\
1.60 \\
3.43 \\
1.39 \\
.97 \\
.56 \\
1.07 \\
.49 \\
.04\end{array}$ & $\begin{array}{r}.05 \\
.58 \\
1.27 \\
1.29 \\
.90 \\
.95 \\
1.31 \\
.61 \\
.05\end{array}$ & $\begin{array}{l}.03 \\
.33 \\
.71 \\
.37 \\
.49 \\
.1 .34 \\
3.30 \\
1.54 \\
.14\end{array}$ & $\begin{array}{l}.03 \\
.40 \\
.87 \\
.62 \\
.40 \\
.74 \\
.78 \\
.43 \\
.04\end{array}$ & $\begin{array}{l}.10 \\
1.12 \\
2.42 \\
.98 \\
.69 \\
.39 \\
.76 \\
.35 \\
.04\end{array}$ & $\begin{array}{l}.04 \\
.41 \\
.90 \\
.91 \\
.64 \\
.67 \\
.93 \\
.43 \\
.04\end{array}$ & $\begin{array}{r}.02 \\
.23 \\
.50 \\
.26 \\
.35 \\
.95 \\
.933 \\
1.09 \\
.10\end{array}$ & $\begin{array}{l}.02 \\
.28 \\
.62 \\
.44 \\
.28 \\
.52 \\
.55 \\
.30 \\
.03\end{array}$ \\
\hline
\end{tabular}

Table A-3b. Fractional deposition (x 100) for injection of debris during Mar-May into the Upper Equatorial Stratosphere $(24-50 \mathrm{~km})$.

\begin{tabular}{|c|c|c|c|c|c|c|c|c|c|c|c|c|c|}
\hline \multirow[b]{2}{*}{ Latitude } & \multicolumn{4}{|c|}{ lst yr } & \multicolumn{4}{|c|}{ 2nd yr } & \multicolumn{4}{|c|}{ 3ed yr } & \multirow{2}{*}{$\begin{array}{l}\text { 4th ye } \\
\text { Mar- } \\
\text { May }\end{array}$} \\
\hline & $\underset{\text { May }}{\text { Mar- }}$ & $\begin{array}{l}\text { June- } \\
\text { Aug }\end{array}$ & $\begin{array}{l}\text { Sept- } \\
\text { Nav }\end{array}$ & $\begin{array}{r}\text { Dee- } \\
\text { Feb }\end{array}$ & Mar- & $\begin{array}{l}\text { June- } \\
\text { Aug }\end{array}$ & $\begin{array}{l}\text { Sept- } \\
\text { Nov }\end{array}$ & $\begin{array}{r}\text { Dec- } \\
\text { Feb }\end{array}$ & $\begin{array}{l}\text { Mar- } \\
\text { May }\end{array}$ & $\begin{array}{l}\text { June- } \\
\text { Aug }\end{array}$ & $\begin{array}{l}\text { Sept- } \\
\text { Nov }\end{array}$ & $\begin{array}{c}\text { Dee- } \\
\text { Feb }\end{array}$ & \\
\hline $\begin{array}{l}70-9 \\
50-7 \\
30-5 \\
10-3 \\
105- \\
10-3 \\
30-5\end{array}$ & $\begin{array}{l}0 \\
0 \\
0 \\
0 \\
0 \\
0 \\
0 \\
0 \\
0\end{array}$ & $\begin{array}{l}.02 \\
.16 \\
.35 \\
.09 \\
.13 \\
.12 \\
.51 \\
.24 \\
.02\end{array}$ & $\begin{array}{c}.04 \\
.45 \\
.96 \\
.23 \\
.40 \\
.79 \\
.95 \\
.91 \\
.08\end{array}$ & $\begin{array}{l}.51 \\
.42 \\
.92 \\
.90 \\
.42 \\
.04\end{array}$ & $\begin{array}{r}.13 \\
1.46 \\
3.13 \\
1.27 \\
.64 \\
.43 \\
.84 \\
.38 \\
.03\end{array}$ & $\begin{array}{r}.04 \\
.54 \\
1.17 \\
1.20 \\
.84 \\
.92 \\
1.28 \\
.60 \\
.05\end{array}$ & $\begin{array}{r}.07 \\
.80 \\
1.71 \\
.41 \\
.54 \\
1.41 \\
3.45 \\
1.61 \\
.15\end{array}$ & $\begin{array}{r}.38 \\
.84 \\
.60 \\
.49 \\
1.09 \\
1.06 \\
.50 \\
.04\end{array}$ & $\begin{array}{l}56 \\
.38 \\
.73\end{array}$ & $\begin{array}{l}.03 \\
.38 \\
.82 \\
.84 \\
.60 \\
.64 \\
.91 \\
.42 \\
.04\end{array}$ & $\begin{array}{r}.05 \\
.57 \\
1.21 \\
.29 \\
.39 \\
1.00 \\
2.44 \\
1.14 \\
.11\end{array}$ & $\begin{array}{l}.35 \\
.77 \\
.75 \\
.35 \\
.03\end{array}$ & $\begin{array}{r}.08 \\
.91 \\
1.96 \\
.79 \\
.40 \\
.27 \\
.52 \\
.23 \\
.02\end{array}$ \\
\hline
\end{tabular}


Table A-3c. Practional depoaition (x 100) for injection of debris during Jun-Aur into the Upper Equatorial Stratosphere $(24-50 \mathrm{~km})$.

\begin{tabular}{|c|c|c|c|c|c|c|c|c|c|c|c|c|c|}
\hline \multirow[b]{2}{*}{ Latitude } & \multicolumn{4}{|c|}{ lst yr } & \multicolumn{4}{|c|}{ and ur } & \multicolumn{4}{|c|}{ 3rd yr } & \multirow{2}{*}{$\begin{array}{l}\text { 4th yr } \\
\text { June- } \\
\text { Aug }\end{array}$} \\
\hline & $\begin{array}{l}\text { June- } \\
\text { Aug }\end{array}$ & $\begin{array}{l}\text { Sept- } \\
\text { Nov }\end{array}$ & $\begin{array}{l}\text { Dec } \\
\text { Feb }\end{array}$ & $\underset{\text { May }}{\text { Mar- }}$ & $\begin{array}{l}\text { June- } \\
\text { Aug }\end{array}$ & $\begin{array}{l}\text { Sept- } \\
\text { Nov }\end{array}$ & $\begin{array}{l}\text { Dec- } \\
\text { Feb }\end{array}$ & $\underset{\text { May }}{\text { Mar- }}$ & $\begin{array}{l}\text { June- } \\
\text { Aug }\end{array}$ & $\begin{array}{l}\text { Sept- } \\
\text { Nov }\end{array}$ & $\begin{array}{l}\text { Dec- } \\
\text { Peb }\end{array}$ & $\underset{\text { May }}{\text { May }}$ & \\
\hline $\begin{array}{l}70-90 \mathrm{~N} \\
50-70 \mathrm{~N} \\
30-50 \mathrm{~N} \\
10-30 \mathrm{~N} \\
10 \mathrm{~S}-10 \mathrm{~N} \\
10-30 \mathrm{~S} \\
30-50 \mathrm{~S} \\
50-70 \mathrm{~S} \\
70-90 \mathrm{~S}\end{array}$ & $\begin{array}{l}0 \\
0 \\
0 \\
0 \\
0 \\
0 \\
0 \\
0 \\
0\end{array}$ & $\begin{array}{l}.02 \\
.21 \\
.45 \\
.11 \\
.23 \\
.24 \\
.99 \\
.46 \\
.04\end{array}$ & $\begin{array}{l}.03 \\
.34 \\
.74 \\
.53 \\
.40 \\
.59 \\
.72 \\
.33 \\
.03\end{array}$ & $\begin{array}{l}.12 \\
1.30 \\
2.90 \\
1.14 \\
.63 \\
.32 \\
.60 \\
.28 \\
.03\end{array}$ & $\begin{array}{l}.04 \\
.48 \\
.74 \\
.67 \\
.51 \\
.71 \\
.98 \\
.46 \\
.04\end{array}$ & $\begin{array}{l}.04 \\
.49 \\
1.07 \\
.56 \\
.89 \\
1.39 \\
3.43 \\
1.60 \\
.14\end{array}$ & $\begin{array}{r}.05 \\
.61 \\
1.31 \\
.95 \\
.80 \\
1.29 \\
1.27 \\
.58 \\
.05\end{array}$ & $\begin{array}{l}.14 \\
2.54 \\
3.30 \\
1.34 \\
.62 \\
.37 \\
.71 \\
.33 \\
.03\end{array}$ & $\begin{array}{l}.04 \\
.43 \\
.78 \\
.74 \\
.40 \\
.62 \\
.87 \\
.40 \\
.03\end{array}$ & $\begin{array}{l}.04 \\
.35 \\
.76 \\
.39 \\
.59 \\
.98 \\
2.42 \\
1.12 \\
.10\end{array}$ & $\begin{array}{l}.04 \\
.43 \\
.93 \\
.67 \\
.57 \\
.91 \\
.90 \\
.41 \\
.04\end{array}$ & $\begin{array}{r}.10 \\
1.09 \\
2.33 \\
.95 \\
.44 \\
.26 \\
.50 \\
.23 \\
.02\end{array}$ & $\begin{array}{l}.03 \\
.30 \\
.55 \\
.52 \\
.28 \\
.44 \\
.62 \\
.28 \\
.02\end{array}$ \\
\hline
\end{tabular}

Table A-3d. Fractional deposition $(x$ 100) for injection of debris during Sep-Nov into the Upper Equatorial Stratosphere $(24-50 \mathrm{~km})$.

\begin{tabular}{|c|c|c|c|c|c|c|c|c|c|c|c|c|c|}
\hline \multirow[b]{2}{*}{ Latitude } & \multicolumn{4}{|c|}{ lst yr } & \multicolumn{4}{|c|}{ and yr } & \multicolumn{4}{|c|}{ 3rd yf } & \multirow{2}{*}{$\begin{array}{c}\text { 4th yr } \\
\text { Sept- } \\
\text { Nov }\end{array}$} \\
\hline & $\begin{array}{l}\text { Sept- } \\
\text { Nov }\end{array}$ & $\begin{array}{c}\text { Dee- } \\
\text { Feb }\end{array}$ & $\begin{array}{c}\text { Mar- } \\
\text { May }\end{array}$ & $\begin{array}{l}\text { June- } \\
\text { Aug }\end{array}$ & $\begin{array}{l}\text { Sept- } \\
\text { Nov }\end{array}$ & $\begin{array}{c}\text { Dec- } \\
\text { Feb }\end{array}$ & $\underset{\text { Mar- }}{\text { May }}$ & $\begin{array}{l}\text { June- } \\
\text { Aug }\end{array}$ & $\begin{array}{l}\text { Sept- } \\
\text { Nov }\end{array}$ & $\begin{array}{c}\text { Dec- } \\
\text { Feb }\end{array}$ & $\underset{\text { May }}{\text { Mar- }}$ & $\begin{array}{l}\text { June- } \\
\text { Aug }\end{array}$ & \\
\hline $\begin{array}{l}70-90 \mathrm{~N} \\
50-70 \mathrm{~N} \\
30-50 \mathrm{~N} \\
10-30 \mathrm{~N} \\
10 \mathrm{~N}-10 \mathrm{~N} \\
10-30 \mathrm{~S} \\
30-50 \mathrm{~S} \\
50-70 \mathrm{~S} \\
70-90 \mathrm{~S}\end{array}$ & $\begin{array}{l}0 \\
0 \\
0 \\
0 \\
0 \\
0 \\
0 \\
0 \\
0\end{array}$ & $\begin{array}{l}.12 \\
.24 \\
.51 \\
.12 \\
.14 \\
.09 \\
.35 \\
.16 \\
.02\end{array}$ & $\begin{array}{r}.08 \\
.91 \\
1.95 \\
.79 \\
.49 \\
.23 \\
.96 \\
.45 \\
.04\end{array}$ & $\begin{array}{l}.04 \\
.42 \\
.90 \\
.92 \\
.52 \\
.51 \\
.71 \\
.33 \\
.03\end{array}$ & $\begin{array}{r}.03 \\
.38 \\
.84 \\
.43 \\
.64 \\
1.27 \\
3.13 \\
1.46 \\
.13\end{array}$ & $\begin{array}{r}.05 \\
.60 \\
1.28 \\
.92 \\
.75 \\
1.20 \\
1.17 \\
.54 \\
.04\end{array}$ & $\begin{array}{r}.15 \\
1.61 \\
3.45 \\
1.41 \\
.76 \\
.41 \\
1.71 \\
.80 \\
.07\end{array}$ & $\begin{array}{r}.04 \\
.50 \\
1.06 \\
1.09 \\
.61 \\
.60 \\
.84 \\
.38 \\
.03\end{array}$ & $\begin{array}{r}.03 \\
.33 \\
.73 \\
.38 \\
.56 \\
1.12 \\
2.77 \\
1.29 \\
.11\end{array}$ & $\begin{array}{l}.04 \\
.42 \\
.91 \\
.64 \\
.53 \\
.84 \\
.82 \\
.38 \\
.03\end{array}$ & $\begin{array}{r}.11 \\
1.14 \\
2.44 \\
1.00 \\
.54 \\
.29 \\
1.21 \\
.57 \\
.05\end{array}$ & $\begin{array}{l}.03 \\
.35 \\
.75 \\
.77 \\
.43 \\
.42 \\
.59 \\
.27 \\
.02\end{array}$ & $\begin{array}{r}.02 \\
.23 \\
.52 \\
.27 \\
.40 \\
.79 \\
1.96 \\
.91 \\
.08\end{array}$ \\
\hline
\end{tabular}


Table A-4a. Fractionsl dopooltion (x 100) for injection of debris during Mas-aug into the Hith Equatorisl Atmospher lahove $50 \mathrm{~km}$ ).

\begin{tabular}{|c|c|c|c|c|c|c|c|c|c|c|c|c|c|c|c|c|c|c|c|c|c|c|c|c|}
\hline Latitude & $\begin{array}{c}\text { Mar- } \\
\text { diney }\end{array}$ & $\begin{array}{c}\text { lat } \\
\text { Junt: } \\
\text { Aus }\end{array}$ & $\begin{array}{l}\text { Yr } \\
\text { Sept- } \\
\text { Hov }\end{array}$ & $\begin{array}{l}\text { Dea } \\
\text { Peb }\end{array}$ & $\begin{array}{l}\text { Mar } \\
\text { May }\end{array}$ & $\begin{array}{c}\text { 2nd } \\
\text { June- } \\
\text { Aus }\end{array}$ & $\begin{array}{l}\text { yr } \\
\text { Sept- } \\
\text { Nor }\end{array}$ & $\underset{\text { Pet }}{\text { Det- }}$ & Mer & $\begin{array}{l}\text { 3rd } \\
\text { Junte- } \\
\text { Aug }\end{array}$ & $\begin{array}{l}\text { yr } \\
\text { Sept- } \\
\text { Nov }\end{array}$ & $\underset{\text { Peb }}{\text { Dec- }}$ & $\begin{array}{c}\text { Mar } \\
\text { May }\end{array}$ & $\begin{array}{c}\text { Lth } \\
\text { June- } \\
\text { Aư }\end{array}$ & $\begin{array}{l}\text { yr } \\
\text { Sept- } \\
\text { Nor }\end{array}$ & $\underset{\text { Feb }}{\text { Det }}$ & $\begin{array}{c}\text { Mar } \\
\text { May }\end{array}$ & $\begin{array}{c}\text { Stb } \\
\text { June } \\
\text { Aщ }\end{array}$ & Sept- & $\underset{\text { Peb }}{\text { Dec- }}$ & Mar & $\begin{array}{c}\text { Gtb } \\
\text { June- } \\
\text { Aug }\end{array}$ & $\begin{array}{l}\text { yr } \\
\text { Sept- } \\
\text { Nov }\end{array}$ & $\begin{array}{l}\text { Dec- } \\
\text { Peb }\end{array}$ \\
\hline $\begin{array}{l}70-90 N \\
30-70 N \\
30-50 N \\
12-30 N \\
105-10 N \\
10-306 \\
30-50 \beta \\
50-708 \\
70-908\end{array}$ & $\begin{array}{l}0 \\
0 \\
0 \\
0 \\
0 \\
0 \\
0 \\
0 \\
0\end{array}$ & $\begin{array}{l}0 \\
0 \\
0 \\
0 \\
0 \\
0 \\
0 \\
0 \\
0\end{array}$ & $\begin{array}{l}0 \\
0 \\
0 \\
0 \\
0 \\
0 \\
0 \\
0 \\
0\end{array}$ & $\begin{array}{l}0 \\
0 \\
0 \\
0 \\
0 \\
0 \\
0 \\
0 \\
0\end{array}$ & $\begin{array}{l}0 \\
0 \\
0 \\
0 \\
0 \\
0 \\
0 \\
0 \\
0\end{array}$ & $\begin{array}{l}0 \\
0 \\
0 \\
0 \\
0 \\
.14 \\
.39 \\
.10 \\
.01\end{array}$ & $\begin{array}{l}0 \\
0 \\
0 \\
0 \\
0 \\
\$ 1 \\
1.50 \\
56 \\
.01\end{array}$ & $\begin{array}{l}.01 \\
.03 \\
.12 \\
.05 \\
.01 \\
.31 \\
.70 \\
.90 \\
.10\end{array}$ & $\begin{array}{l}.01 \\
.26 \\
.71 \\
.24 \\
.04 \\
.28 \\
.50 \\
.47 \\
.03\end{array}$ & $\begin{array}{l}.04 \\
.06 \\
.28 \\
.13 \\
.05 \\
1.37 \\
3.80 \\
1.00 \\
.00\end{array}$ & $\begin{array}{l}.01 \\
.17 \\
.18 \\
.10 \\
.08 \\
2.54 \\
7.47 \\
276 \\
.09\end{array}$ & $\begin{array}{r}.02 \\
.32 \\
1.20 \\
.13 \\
.11 \\
.79 \\
1.16 \\
2.26 \\
.28\end{array}$ & $\begin{array}{r}.03 \\
.87 \\
2.37 \\
.01 \\
.12 \\
.41 \\
.71 \\
.64 \\
.04\end{array}$ & $\begin{array}{l}.08 \\
.21 \\
.56 \\
.25 \\
.09 \\
.86 \\
2.40 \\
.63 \\
.05\end{array}$ & $\begin{array}{r}.01 \\
.21 \\
.23 \\
.13 \\
.10 \\
1.60 \\
6.70 \\
1.74 \\
.06\end{array}$ & $\begin{array}{l}.01 \\
.20 \\
.76 \\
.27 \\
.07 \\
.50 \\
1.10 \\
1.49 \\
.10\end{array}$ & $\begin{array}{r}.02 \\
.55 \\
1.49 \\
.51 \\
.08 \\
.28 \\
.46 \\
.43 \\
.63\end{array}$ & $\begin{array}{l}.05 \\
.15 \\
.35 \\
.16 \\
.06 \\
.51 \\
1.51 \\
.40 \\
.03\end{array}$ & $\begin{array}{l}.01 \\
.13 \\
.14 \\
.08 \\
.06 \\
1.01 \\
2.97 \\
1.10 \\
.03\end{array}$ & $\begin{array}{l}.01 \\
.19 \\
.48 \\
.17 \\
.04 \\
.31 \\
.70 \\
.00 \\
.10\end{array}$ & $\begin{array}{l}.01 \\
.35 \\
.01 \\
.32 \\
.05 \\
.17 \\
.20 \\
.27 \\
.01\end{array}$ & $\begin{array}{l}.03 \\
.29 \\
.22 \\
.10 \\
.04 \\
.34 \\
.86 \\
.26 \\
.01\end{array}$ & $\begin{array}{l}.01 \\
.09 \\
.09 \\
.05 \\
.01 \\
.64 \\
1.87 \\
.70 \\
.01\end{array}$ & $\begin{array}{l}.01 \\
.08 \\
.90 \\
.11 \\
.07 \\
.20 \\
.44 \\
.57 \\
.06\end{array}$ \\
\hline
\end{tabular}

Table A-4b. Fractional depogition $(x$ 100) for injection of depris during Sep-Fab into the High Enuatorsi stmospivere (ahove $50 \mathrm{~km}$ ).

\begin{tabular}{|c|c|c|c|c|c|c|c|c|c|c|c|c|c|c|c|c|c|c|c|c|c|c|c|c|}
\hline Letitude & $\begin{array}{l}\text { Sept- } \\
\text { Nov }\end{array}$ & $\begin{array}{c}\text { lat } \\
\text { Det } \\
\text { Feb }\end{array}$ & $\underset{\text { Mar- }}{y \mathbf{r}}$ & $\begin{array}{l}\text { June- } \\
\text { Aug }\end{array}$ & $\begin{array}{l}\text { Sept- } \\
\text { Nov }\end{array}$ & $\begin{array}{c}\text { Znd } \\
\text { Wee- } \\
\text { Feb }\end{array}$ & $\begin{array}{l}\text { ye } \\
\text { Mar- } \\
\text { May }\end{array}$ & $\begin{array}{l}\text { June- } \\
\text { Aug }\end{array}$ & Sept- & $\begin{array}{c}\text { Jrd } \\
\text { Dec- } \\
\text { Feb }\end{array}$ & $\underset{\text { May }}{\text { yr }}$ & $\begin{array}{l}\text { June- } \\
\text { Augg }\end{array}$ & $\begin{array}{l}\text { Sept: } \\
\text { Nov }\end{array}$ & $\begin{array}{c}\text { 4th } \\
\text { Fet }\end{array}$ & $\underset{\text { May }}{\text { Mr }}$ & $\begin{array}{c}\text { June- } \\
\text { Augg }\end{array}$ & $\begin{array}{l}\text { Sept- } \\
\text { Nov }\end{array}$ & $\begin{array}{c}5 \mathrm{sth} \\
\text { Doeb }\end{array}$ & $\begin{array}{l}\text { ye } \\
\text { Mar- } \\
\text { May }\end{array}$ & $\begin{array}{l}\text { June- } \\
\text { Aug }\end{array}$ & $\begin{array}{l}\text { Sept- } \\
\text { Nov }\end{array}$ & $\begin{array}{c}\text { Beth } \\
\text { Peb }\end{array}$ & $\begin{array}{l}\text { Mar- } \\
\text { Mey }\end{array}$ & $\begin{array}{l}\text { June- } \\
\text { Aug }\end{array}$ \\
\hline $\begin{array}{l}70-800 \\
50-70 N \\
30-50 N \\
10-30 N \\
100-10 \mathrm{~N} \\
10-305 \\
30-505 \\
50-705 \\
70-908\end{array}$ & $\begin{array}{l}0 \\
0 \\
0 \\
0 \\
0 \\
0 \\
0 \\
0 \\
0\end{array}$ & $\begin{array}{l}0 \\
0 \\
0 \\
0 \\
0 \\
0 \\
0 \\
0 \\
0\end{array}$ & $\begin{array}{l}0 \\
0 \\
0 \\
0 \\
0 \\
0 \\
0 \\
0 \\
0\end{array}$ & $\begin{array}{l}0 \\
0 \\
0 \\
0 \\
0 \\
0 \\
0 \\
0 \\
0\end{array}$ & $\begin{array}{l}0 \\
0 \\
0 \\
0 \\
0 \\
0 \\
0 \\
0 \\
0\end{array}$ & $\begin{array}{l}.01 \\
.10 \\
.39 \\
.14 \\
0 \\
0 \\
0 \\
0 \\
0\end{array}$ & $\begin{array}{l}.01 \\
.56 \\
1.50 \\
.51 \\
0 \\
0 \\
0 \\
0 \\
0\end{array}$ & $\begin{array}{l}.10 \\
.90 \\
.70 \\
.31 \\
.01 \\
.05 \\
.12 \\
.03 \\
.01\end{array}$ & $\begin{array}{l}.03 \\
.47 \\
.50 \\
.29 \\
.04 \\
.24 \\
.71 \\
.26 \\
.01\end{array}$ & $\begin{array}{l}.08 \\
1.00 \\
3.80 \\
1.37 \\
.05 \\
.13 \\
.28 \\
.36 \\
.04\end{array}$ & $\begin{array}{r}.08 \\
2.76 \\
7.47 \\
2.54 \\
.08 \\
.10 \\
.18 \\
.17 \\
.01\end{array}$ & $\begin{array}{r}.26 \\
2.26 \\
1.76 \\
.79 \\
.11 \\
.43 \\
1.20 \\
.32 \\
.02\end{array}$ & $\begin{array}{l}.04 \\
.67 \\
.71 \\
.41 \\
.12 \\
.81 \\
2.37 \\
.87 \\
.03\end{array}$ & $\begin{array}{l}.05 \\
.63 \\
2.40 \\
.86 \\
.09 \\
.25 \\
.56 \\
.71 \\
.08\end{array}$ & $\begin{array}{l}.06 \\
1.74 \\
4.70 \\
1.60 \\
.10 \\
.13 \\
.23 \\
.21 \\
.01\end{array}$ & $\begin{array}{l}.16 \\
1.43 \\
1.10 \\
.50 \\
.07 \\
.27 \\
.76 \\
.20 \\
.01\end{array}$ & $\begin{array}{r}.03 \\
.43 \\
.46 \\
.26 \\
.00 \\
.51 \\
1.49 \\
.55 \\
.02\end{array}$ & $\begin{array}{r}.03 \\
.10 \\
1 . \$ 1 \\
.54 \\
.06 \\
.16 \\
.15 \\
.45 \\
.05\end{array}$ & $\begin{array}{l}.03 \\
1.10 \\
2.97 \\
1.01 \\
.06 \\
.08 \\
.14 \\
.13 \\
.01\end{array}$ & $\begin{array}{l}.10 \\
.90 \\
.70 \\
.31 \\
.04 \\
.17 \\
.48 \\
.13 \\
.01\end{array}$ & $\begin{array}{l}.01 \\
.27 \\
.29 \\
.17 \\
.05 \\
.32 \\
.94 \\
.35 \\
.01\end{array}$ & $\begin{array}{l}.01 \\
.26 \\
.96 \\
.34 \\
.04 \\
.10 \\
.22 \\
.29 \\
.03\end{array}$ & $\begin{array}{l}.01 \\
.70 \\
1.87 \\
.64 \\
.04 \\
.05 \\
.09 \\
.09 \\
.01\end{array}$ & $\begin{array}{l}.06 \\
.57 \\
.44 \\
.20 \\
.03 \\
.11 \\
.30 \\
.08 \\
.01\end{array}$ \\
\hline
\end{tabular}


Table A-5a. Fractional deposition (x 100) for injection of debris during Dec-Feb into the Lower Polar Stratosphere $(9-17 \mathrm{~km})$.

\begin{tabular}{lcccccccc} 
Latitude & $\begin{array}{c}\text { Dee- } \\
\text { Feb }\end{array}$ & $\begin{array}{c}\text { Mar } \\
\text { May }\end{array}$ & $\begin{array}{c}\text { June- } \\
\text { Aug }\end{array}$ & $\begin{array}{c}\text { Sept- } \\
\text { Nov }\end{array}$ & $\begin{array}{c}\text { Dec- } \\
\text { Feb }\end{array}$ & $\begin{array}{c}\text { Mar } \\
\text { May }\end{array}$ & $\begin{array}{r}\text { dune- } \\
\text { Aug }\end{array}$ & $\begin{array}{r}\text { Sept- } \\
\text { Nov }\end{array}$ \\
\hline $70-90 N$ & .27 & .69 & .54 & .09 & .15 & .23 & .13 & .02 \\
$50-70 N$ & 286 & 6.60 & 5.11 & .80 & 1.50 & 1.35 & 1.21 & .34 \\
$30-50 N$ & 4.94 & 25.03 & .99 & 2.00 & 2.15 & 2.59 & .94 & .38 \\
$10-30 N$ & 1.52 & 9.17 & 1.43 & 1.20 & 1.62 & 1.91 & .43 & .23 \\
$105-10 N$ & .23 & 1.06 & .35 & .51 & .92 & .56 & .08 & .10 \\
$10-30 S$ & .29 & .55 & .25 & .33 & .10 & .05 & .06 & .06 \\
$30-50 S$ & .07 & .27 & .43 & .29 & .12 & .05 & .10 & .05 \\
$50-70 S$ & .05 & .07 & .10 & .07 & .02 & .02 & .02 & .01 \\
$70-90 S$ & 0 & 0 & .01 & 0 & 0 & 0 & 0 & 0 \\
\hline
\end{tabular}

Table A-5b. Fractional deposition $(x$ 100) for injection of debr: unis liar-May into the Lower Poler Stratosphere $(9-17 \mathrm{~km})$.

\begin{tabular}{|c|c|c|c|c|c|c|c|c|}
\hline \multirow[b]{2}{*}{ atitude } & \multicolumn{4}{|c|}{ lst yr } & \multicolumn{4}{|c|}{$2 r: y r$} \\
\hline & $\begin{array}{c}\text { Mar- } \\
\text { May }\end{array}$ & $\begin{array}{l}\text { June- } \\
\text { Aug }\end{array}$ & $\begin{array}{r}\text { Sept- } \\
\text { Nov }\end{array}$ & $\begin{array}{r}\text { Dec- } \\
\text { Feb }\end{array}$ & $\begin{array}{c}\text { Mar- } \\
\text { May }\end{array}$ & $\begin{array}{l}\text { June- } \\
\text { Aug }\end{array}$ & $\begin{array}{l}\text { Sept- } \\
\text { Nov }\end{array}$ & $\begin{array}{r}\text { Dee- } \\
\text { Feb }\end{array}$ \\
\hline $\begin{array}{l}70-90 \mathrm{~N} \\
50-70 \mathrm{~N} \\
30-50 \mathrm{~N} \\
10.30 \mathrm{~N} \\
10 \mathrm{~S}-10 \mathrm{~N} \\
10-30 \mathrm{~S} \\
30-50 \mathrm{~S} \\
50-70 \mathrm{~S} \\
70-90 \mathrm{~S}\end{array}$ & $\begin{array}{r}.43 \\
4.46 \\
7.72 \\
2.38 \\
.35 \\
.20 \\
.05 \\
.07 \\
0\end{array}$ & $\begin{array}{l}.19 \\
1.85 \\
7.00 \\
2.15 \\
.30 \\
.16 \\
.08 \\
.02\end{array}$ & $\begin{array}{l}.22 \\
2.50 \\
5.00 \\
2.00 \\
.60 \\
.30 \\
.52 \\
.17 \\
.01\end{array}$ & $\begin{array}{l}.20 \\
3.97 \\
7.74 \\
3.50 \\
.30 \\
.23 \\
.20 \\
.07 \\
0\end{array}$ & $\begin{array}{r}.18 \\
5.51 \\
15.01 \\
5.11 \\
.46 \\
.10 \\
.15 \\
.14\end{array}$ & $\begin{array}{l}.27 \\
2.56 \\
1.99 \\
.91 \\
.18 \\
.13 \\
.11 \\
.05\end{array}$ & $\begin{array}{l}.04 \\
.47 \\
.95 \\
.38 \\
.11 \\
.06 \\
.14 \\
.03\end{array}$ & $\begin{array}{l}.03 \\
.75 \\
1.46 \\
.66 \\
.06 \\
.04 \\
.04 \\
.01\end{array}$ \\
\hline
\end{tabular}


Table A-5e. Fractional deposition (x 100) for infection of debris during Jun-Aug into the Lower Polar Stratosphere (9-17 km).

\begin{tabular}{lcccccccc} 
Latitude & $\begin{array}{c}\text { June- } \\
\text { Aug }\end{array}$ & $\begin{array}{c}\text { Sept- } \\
\text { Nov }\end{array}$ & $\begin{array}{r}\text { Dec- } \\
\text { Feb }\end{array}$ & $\begin{array}{c}\text { Mar- } \\
\text { May }\end{array}$ & $\begin{array}{c}\text { Jure- } \\
\text { Aug }\end{array}$ & $\begin{array}{r}\text { Sept- } \\
\text { Nov }\end{array}$ & $\begin{array}{r}\text { Dec- } \\
\text { Feb }\end{array}$ & $\begin{array}{r}\text { Mar- } \\
\text { May }\end{array}$ \\
\hline 70-90N & .18 & .19 & .18 & .21 & .38 & .03 & .04 & .04 \\
$50-70 N$ & 1.89 & 1.79 & 3.43 & 6.42 & 3.58 & .63 & .91 & 1.21 \\
$30-50 N$ & 3.26 & 6.79 & 12.99 & 17.51 & .79 & .70 & .97 & 3.31 \\
$10-30 N$ & 1.01 & 249 & 4.76 & $\mathbf{5 . 9 6}$ & 1.28 & .42 & .65 & 1.13 \\
$105-10 N$ & .15 & .29 & .55 & .53 & .25 & .18 & .37 & .10 \\
$10-305$ & .19 & .15 & .29 & .11 & .18 & .12 & .04 & .02 \\
$30-50 S$ & .05 & .07 & .14 & .34 & .30 & .10 & .05 & .06 \\
$50-705$ & .03 & .02 & .03 & .16 & .07 & .02 & .01 & .01 \\
$70-90 S$ & 0 & 0 & 0 & .01 & .01 & 0 & 0 & 0 \\
\hline
\end{tabular}

Table A-5J. Fractional deposition (x 100) for injection of debris duting Sep-Nov into the Lower Polar Stratosphere $(9-17 \mathrm{~km})$.

\begin{tabular}{|c|c|c|c|c|c|c|c|c|}
\hline \multirow[b]{2}{*}{ Latitude } & \multicolumn{4}{|c|}{ lst yp } & \multicolumn{4}{|c|}{ 2nd yr } \\
\hline & $\begin{array}{l}\text { Sept- } \\
\text { Nov }\end{array}$ & $\begin{array}{l}\text { Dee- } \\
\text { Reb }\end{array}$ & $\begin{array}{c}\text { Mar- } \\
\text { May }\end{array}$ & $\begin{array}{l}\text { June- } \\
\text { \&ug }\end{array}$ & $\begin{array}{l}\text { Sept- } \\
\text { Nov }\end{array}$ & $\begin{array}{c}\text { Dec- } \\
\text { Feb }\end{array}$ & $\underset{\text { May }}{\text { Mar- }}$ & $\begin{array}{l}\text { June- } \\
\text { Aug }\end{array}$ \\
\hline $\begin{array}{l}70-90 N \\
50-70 N \\
30-50 N \\
10-30 N \\
105-10 N \\
10-30 S \\
30-50 S \\
50-70 S \\
70-90 S\end{array}$ & $\begin{array}{l}.23 \\
240 \\
4.15 \\
1.28 \\
.19 \\
.24 \\
.06 \\
.04\end{array}$ & $\begin{array}{r}.21 \\
3.93 \\
14.90 \\
5.46 \\
.63 \\
.33 \\
.16 \\
.04 \\
0\end{array}$ & $\begin{array}{r}.24 \\
7.34 \\
20.01 \\
6.81 \\
.61 \\
.13 \\
.39 \\
.18 \\
.01\end{array}$ & $\begin{array}{l}.43 \\
4.09 \\
.19 \\
1.46 \\
.28 \\
.20 \\
.34 \\
.08 \\
.01\end{array}$ & $\begin{array}{l}.04 \\
.81 \\
.90 \\
.54 \\
.23 \\
.15 \\
.13 \\
.03 \\
0\end{array}$ & $\begin{array}{r}.07 \\
.70 \\
1.00 \\
.78 \\
.44 \\
.05 \\
.06 \\
.01 \\
0\end{array}$ & $\begin{array}{l}.10 \\
.58 \\
1.11 \\
.82 \\
.24 \\
.02 \\
.02 \\
.01 \\
0\end{array}$ & $\begin{array}{l}.06 \\
.30 \\
.28 \\
.25 \\
.05 \\
.01 \\
.01 \\
.01 \\
0\end{array}$ \\
\hline
\end{tabular}


Table A-6a. Fractlonal deposition (x 100) tor injection of debris during Dee-Feb into the Upper Poler Stratosphere $(17-50 \mathrm{~km})$.

\begin{tabular}{|c|c|c|c|c|c|c|c|c|c|c|c|c|c|c|}
\hline Latitude & $\begin{array}{c}\text { Dee- } \\
\text { Peb }\end{array}$ & $\underset{\text { Mar- }}{\text { May }}$ & $\begin{array}{l}\text { yr } \\
\text { June- } \\
\text { Aug }\end{array}$ & $\begin{array}{l}\text { Sept- } \\
\text { Nov }\end{array}$ & $\begin{array}{c}\text { Dec- } \\
\text { Feb }\end{array}$ & $\begin{array}{c}\text { 2nd } \\
\text { Mar- } \\
\text { May }\end{array}$ & $\begin{array}{l}\text { yr } \\
\text { June- } \\
\text { Aug }\end{array}$ & $\mathrm{Se}_{\mathrm{k}}$ & $\begin{array}{c}\text { Dec- } \\
\text { Feb }\end{array}$ & $\begin{array}{c}\text { 3rd } \\
\text { Mar- } \\
\text { May }\end{array}$ & $\begin{array}{l}\text { yir } \\
\text { June- } \\
\text { Aug }\end{array}$ & $\begin{array}{l}\text { Sept- } \\
\text { Nov }\end{array}$ & $\begin{array}{c}\text { 4th } \\
\text { Dee- } \\
\text { Peb }\end{array}$ & $\begin{array}{l}\text { yr } \\
\text { Mar } \\
\text { May }\end{array}$ \\
\hline $\begin{array}{l}70-90 \mathrm{~N} \\
50-70 \mathrm{~N} \\
30-50 \mathrm{~N} \\
10-30 \mathrm{~N} \\
10 \mathrm{~S}-10 \mathrm{~N} \\
10-30 \mathrm{~S} \\
30-50 \mathrm{OS} \\
50-70 \mathrm{~S} \\
70-90 \mathrm{~S}\end{array}$ & $\begin{array}{l}.02 \\
.07 \\
.20 \\
.05 \\
0 \\
0 \\
0 \\
0 \\
0\end{array}$ & $\begin{array}{r}.06 \\
.58 \\
218 \\
.52 \\
.03 \\
.01 \\
.02 \\
0 \\
0\end{array}$ & $\begin{array}{l}.16 \\
1.50 \\
1.18 \\
.54 \\
.05 \\
.06 \\
.02 \\
.05\end{array}$ & $\begin{array}{l}.06 \\
1.14 \\
1.27 \\
.76 \\
.17 \\
.23 \\
.66 \\
.24 \\
.01\end{array}$ & $\begin{array}{l}.13 \\
1.50 \\
2.58 \\
1.74 \\
.10 \\
.12 \\
.27 \\
.34 \\
.04\end{array}$ & $\begin{array}{l}.19 \\
1.81 \\
6.88 \\
1.66 \\
.10 \\
.08 \\
.11 \\
.06 \\
.01\end{array}$ & $\begin{array}{l}.20 \\
1.89 \\
1.48 \\
.68 \\
.09 \\
.32 \\
.86 \\
.23 \\
.03\end{array}$ & $\begin{array}{r}.05 \\
.90 \\
1.00 \\
.60 \\
.15 \\
.53 \\
1.57 \\
.58 \\
.02\end{array}$ & $\begin{array}{l}.09 \\
1.00 \\
1.63 \\
1.09 \\
.08 \\
.15 \\
.34 \\
.43 \\
.05\end{array}$ & $\begin{array}{l}.12 \\
1.14 \\
4.33 \\
1.04 \\
.06 \\
.08 \\
.11 \\
.06 \\
.01\end{array}$ & $\begin{array}{r}.13 \\
1.19 \\
.93 \\
.43 \\
.05 \\
.20 \\
.55 \\
.14 \\
.02\end{array}$ & $\begin{array}{l}.03 \\
.57 \\
.63 \\
.38 \\
.10 \\
.34 \\
.99 \\
.36 \\
.01\end{array}$ & $\begin{array}{r}.05 \\
.65 \\
1.02 \\
.69 \\
.05 \\
.10 \\
.21 \\
.27 \\
.03\end{array}$ & $\begin{array}{r}.08 \\
.72 \\
2.73 \\
.66 \\
.04 \\
.05 \\
.13 \\
.04 \\
.01\end{array}$ \\
\hline
\end{tabular}

Table A-fb. Fractional deposition (x 100) for injection of debris during Mar-May into the Upper Polar Stratosphere (17-50 km).

\begin{tabular}{|c|c|c|c|c|c|c|c|c|c|c|c|c|c|c|}
\hline Latitude & $\begin{array}{l}\text { Mar- } \\
\text { May }\end{array}$ & $\begin{array}{l}\text { lst } \\
\text { June- } \\
\text { Aug }\end{array}$ & $\begin{array}{l}\text { yr } \\
\text { Sept- } \\
\text { Nov }\end{array}$ & $\begin{array}{l}\text { Dee- } \\
\text { Feb }\end{array}$ & $\begin{array}{c}\text { Mar- } \\
\text { May }\end{array}$ & $\begin{array}{l}\text { 2nd } \\
\text { June- } \\
\text { Aug }\end{array}$ & $\begin{array}{l}\text { yr } \\
\text { Sept- } \\
\text { Nov }\end{array}$ & $\begin{array}{r}\text { Dec- } \\
\text { Peb }\end{array}$ & $\underset{\text { May }}{\text { Mar- }}$ & $\begin{array}{l}\text { 3rd } \\
\text { June- } \\
\text { Aug }\end{array}$ & $\begin{array}{l}\text { yr } \\
\text { Sept- } \\
\text { Nov }\end{array}$ & $\begin{array}{c}\text { Dec- } \\
\text { Feb }\end{array}$ & $\underset{\text { May }}{4 \mathrm{th}}$ & $\begin{array}{l}\text { yr } \\
\text { June- } \\
\text { Aug }\end{array}$ \\
\hline $\begin{array}{l}70-90 \mathrm{~N} \\
50-70 \mathrm{~N} \\
30-50 \mathrm{~N} \\
10-30 \mathrm{~N} \\
10 \mathrm{~S}-10 \mathrm{~N} \\
10-30 \mathrm{~S} \\
3 \mathrm{C}-5 \bar{S} \\
50-70 \mathrm{~S} \\
70-90 \mathrm{~S}\end{array}$ & $\begin{array}{l}.08 \\
.14 \\
.30 \\
.08 \\
0 \\
0 \\
0 \\
0 \\
0\end{array}$ & $\begin{array}{l}.01 \\
.11 \\
.42 \\
.13 \\
.01 \\
.02 \\
.06 \\
.01 \\
0\end{array}$ & $\begin{array}{r}.04 \\
.51 \\
1.01 \\
.41 \\
.07 \\
.11 \\
.33 \\
.12 \\
0\end{array}$ & $\begin{array}{r}.10 \\
1.74 \\
3.39 \\
1.91 \\
.08 \\
.07 \\
.15 \\
.19 \\
.02\end{array}$ & $\begin{array}{r}.13 \\
4.07 \\
11.08 \\
3.77 \\
.18 \\
.07 \\
.11 \\
.10 \\
.01\end{array}$ & $\begin{array}{r}.04 \\
.35 \\
1.33 \\
.41 \\
.04 \\
.23 \\
.61 \\
.16 \\
.02\end{array}$ & $\begin{array}{r}.06 \\
.64 \\
1.28 \\
.51 \\
.11 \\
.57 \\
1.67 \\
.61 \\
.02\end{array}$ & $\begin{array}{r}.07 \\
1.37 \\
2.67 \\
1.21 \\
.07 \\
.17 \\
.36 \\
.46 \\
.05\end{array}$ & $\begin{array}{r}.08 \\
2.56 \\
6.98 \\
2.38 \\
.13 \\
.08 \\
.14 \\
.12 \\
.01\end{array}$ & $\begin{array}{l}.02 \\
.22 \\
.83 \\
.26 \\
.03 \\
.21 \\
.58 \\
.15 \\
.02\end{array}$ & $\begin{array}{r}.04 \\
.40 \\
.80 \\
.32 \\
.07 \\
.36 \\
1.05 \\
.39 \\
.01\end{array}$ & $\begin{array}{r}.04 \\
.86 \\
1.68 \\
.76 \\
.04 \\
.10 \\
.23 \\
.29 \\
.03\end{array}$ & $\begin{array}{l}.05 \\
1.61 \\
4.40 \\
1.50 \\
.08 \\
.05 \\
.09 \\
.08 \\
.0\end{array}$ & $\begin{array}{l}.01 \\
.14 \\
.52 \\
.16 \\
.02 \\
.13 \\
.37 \\
.09 \\
.01\end{array}$ \\
\hline
\end{tabular}


Table A-6c. Fractional deposition $(x$ 100) for injection of debris during Jun-Aug into the Upper Polar Stratosphere (17-50 km).

\begin{tabular}{|c|c|c|c|c|c|c|c|c|c|c|c|c|c|c|}
\hline \multirow[b]{2}{*}{ Latitude } & \multicolumn{4}{|c|}{ 1st $\mathrm{yr}$} & \multicolumn{4}{|c|}{ 2nd yr } & \multicolumn{4}{|c|}{ 3rd yr } & \multicolumn{2}{|c|}{4 th y } \\
\hline & $\begin{array}{l}\text { June- } \\
\text { Aug }\end{array}$ & $\begin{array}{l}\text { Sept- } \\
\text { Nov }\end{array}$ & $\begin{array}{l}\text { Dec- } \\
\text { Feb }\end{array}$ & $\underset{\text { May }}{\text { Mar- }}$ & $\begin{array}{l}\text { June- } \\
\text { Aus }\end{array}$ & $\begin{array}{l}\text { Sept- } \\
\text { Nov }\end{array}$ & Dec- & $\begin{array}{c}\text { Mar- } \\
\text { May }\end{array}$ & $\begin{array}{r}\text { June- } \\
\text { Aug }\end{array}$ & $\begin{array}{l}\text { Sept- } \\
\text { Nov }\end{array}$ & Peb & $\underset{\text { May }}{\operatorname{Mar}}$ & $\begin{array}{l}\text { June } \\
\text { Aug }\end{array}$ & Sept- \\
\hline $\begin{array}{l}70-90 N \\
50-70 N \\
30-50 N \\
10-30 N \\
10 S-10 \mathrm{~N} \\
10-30 S \\
30-50 S \\
50-70 S \\
70-90 S\end{array}$ & $\begin{array}{l}.01 \\
.04 \\
.15 \\
.03 \\
0 \\
0 \\
0 \\
0 \\
0\end{array}$ & $\begin{array}{l}.01 \\
.11 \\
.41 \\
.15 \\
.01 \\
.03 \\
.12 \\
.03 \\
0\end{array}$ & $\begin{array}{l}.07 \\
.70 \\
2.66 \\
.87 \\
.06 \\
.04 \\
.08 \\
.10 \\
.01\end{array}$ & $\begin{array}{r}.09 \\
284 \\
7.73 \\
2.63 \\
.13 \\
.07 \\
.12 \\
.11 \\
.01\end{array}$ & $\begin{array}{r}.28 \\
2.67 \\
2.08 \\
.95 \\
.11 \\
.24 \\
.36 \\
.33 \\
.06\end{array}$ & $\begin{array}{r}.04 \\
.34 \\
1.30 \\
.47 \\
.05 \\
.31 \\
.27 \\
.33 \\
.04\end{array}$ & $\begin{array}{r}.06 \\
.88 \\
3.35 \\
1.23 \\
.09 \\
.19 \\
.41 \\
.52 \\
.06\end{array}$ & $\begin{array}{l}.07 \\
2.23 \\
6.09 \\
2.07 \\
.13 \\
.17 \\
.28 \\
.25 \\
.01\end{array}$ & $\begin{array}{l}.18 \\
1.68 \\
1.31 \\
.60 \\
.08 \\
.30 \\
.45 \\
.42 \\
.10\end{array}$ & $\begin{array}{r}.02 \\
.22 \\
.82 \\
.30 \\
.04 \\
.29 \\
1.20 \\
.32 \\
.03\end{array}$ & $\begin{array}{l}.04 \\
.56 \\
2.11 \\
.77 \\
.04 \\
.12 \\
.26 \\
.33 \\
.04\end{array}$ & $\begin{array}{l}.05 \\
1.41 \\
3.83 \\
1.31 \\
.08 \\
.10 \\
.17 \\
.16 \\
.01\end{array}$ & $\begin{array}{l}.11 \\
1.06 \\
.82 \\
.38 \\
.05 \\
.19 \\
.28 \\
.27 \\
.05\end{array}$ & $\begin{array}{l}.01 \\
.14 \\
.52 \\
.19 \\
.03 \\
.18 \\
.76 \\
.20 \\
.02\end{array}$ \\
\hline
\end{tabular}

Table A-6d. Fractional deposition (x 100) for injection of debris during Sep-Nov inta the Upper Polar Strstosphere (17-50 km).

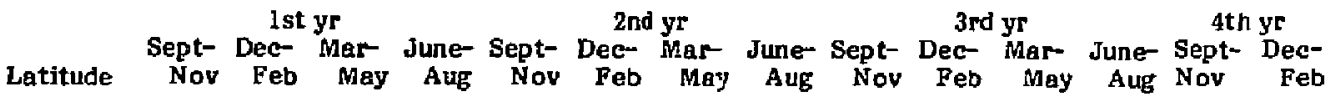

\begin{tabular}{|c|c|c|c|c|c|c|c|c|c|c|c|c|c|c|}
\hline $\begin{array}{l}70-90 N \\
50-70 N \\
30-50 N \\
10-30 \mathrm{~N} \\
10 S-10 \mathrm{~N} \\
10-30 \mathrm{~S} \\
30-50 S \\
50-705 \\
70-90 \mathrm{~S}\end{array}$ & $\begin{array}{l}.02 \\
.06 \\
.17 \\
.04 \\
0 \\
0 \\
0 \\
0 \\
0\end{array}$ & $\begin{array}{l}.03 \\
.29 \\
1.11 \\
.41 \\
.02 \\
.01 \\
.02 \\
.01 \\
.0\end{array}$ & $\begin{array}{l}.06 \\
1.84 \\
5.02 \\
1.71 \\
.08 \\
.02 \\
.07 \\
.03\end{array}$ & $\begin{array}{r}.23 \\
2.22 \\
1.73 \\
.79 \\
.08 \\
.13 \\
.29 \\
.15 \\
.01\end{array}$ & $\begin{array}{r}.04 \\
.74 \\
.82 \\
.50 \\
.12 \\
.48 \\
1.41 \\
.52 \\
.02\end{array}$ & $\begin{array}{l}.06 \\
.92 \\
3.50 \\
1.28 \\
.07 \\
.07 \\
.23 \\
.06 \\
.01\end{array}$ & $\begin{array}{r}.08 \\
2.32 \\
6.33 \\
2.15 \\
.12 \\
.13 \\
.33 \\
.16 \\
.02\end{array}$ & $\begin{array}{l}.18 \\
1.74 \\
1.36 \\
.62 \\
.07 \\
.31 \\
.68 \\
.35 \\
.03\end{array}$ & $\begin{array}{l}.02 \\
.47 \\
.52 \\
.31 \\
.10 \\
.61 \\
1.78 \\
.65 \\
.02\end{array}$ & $\begin{array}{l}.04 \\
.58 \\
2.20 \\
.81 \\
.05 \\
.07 \\
.21 \\
.06 \\
.01\end{array}$ & $\begin{array}{l}.05 \\
1.46 \\
3.99 \\
1.36 \\
.07 \\
.08 \\
.21 \\
.10 \\
.01\end{array}$ & $\begin{array}{l}.12 \\
1.10 \\
.86 \\
.39 \\
.05 \\
.19 \\
.43 \\
.22 \\
.02\end{array}$ & $\begin{array}{l}.01 \\
.29 \\
.33 \\
.20 \\
.06 \\
.38 \\
1.12 \\
.41 \\
.01\end{array}$ & $\begin{array}{r}.02 \\
.37 \\
. .39 \\
.51 \\
.03 \\
.04 \\
.13 \\
.04 \\
.01\end{array}$ \\
\hline
\end{tabular}


Table A-7a. Ercetlonni depasition (x 100) tor injectlon of Jebris ouring Mar-nug into the lligh Poiar Atmosphere (above $50 \mathrm{~km}$ ).

\begin{tabular}{|c|c|c|c|c|c|c|c|c|c|c|c|c|c|c|c|c|c|c|c|c|c|c|c|c|}
\hline atitude & $\begin{array}{l}\text { Mar- } \\
\text { Mey }\end{array}$ & $\begin{array}{c}\text { Ist } \\
\text { June } \\
\text { Aus }\end{array}$ & $\begin{array}{l}\text { yr } \\
\text { Sept- } \\
\text { Nov }\end{array}$ & $\underset{\text { Heb }}{\text { Dec- }}$ & $\underset{\text { May }}{\text { Mar }}$ & $\begin{array}{l}\text { 2nd } \\
\text { June- } \\
\text { aus }\end{array}$ & $\begin{array}{l}\text { yr } \\
\text { Sept- } \\
\text { Nov }\end{array}$ & $\underset{\text { Bob }}{\text { Doc }}$ & $\begin{array}{c}\text { Mar. } \\
\text { Mny }\end{array}$ & $\begin{array}{c}\text { Jed } \\
\text { Junnt- } \\
\text { Augs }\end{array}$ & $\begin{array}{l}\text { yr } \\
\text { Scpt- } \\
\text { Nor }\end{array}$ & DOE & $\begin{array}{c}\text { Mar } \\
\text { May }\end{array}$ & $\begin{array}{r}\mathbf{4 l h} \\
\text { June- } \\
\Lambda \cup g\end{array}$ & $\begin{array}{l}\text { yr } \\
\text { Sept- } \\
\text { Nov }\end{array}$ & $\underset{\text { Feb }}{\text { Dec- }}$ & $\begin{array}{l}\text { Mar } \\
\text { May }\end{array}$ & $\begin{array}{l}51 h \\
\text { June- } \\
\text { Aug }\end{array}$ & $\begin{array}{l}\text { Novt- } \\
\text { iept }\end{array}$ & $\begin{array}{l}\text { Dec } \\
\text { Feb }\end{array}$ & $\operatorname{Mar}_{\text {May }}$ & $\begin{array}{c}\text { 6th } \\
\text { Jane- } \\
\text { Aug }\end{array}$ & $\begin{array}{l}\text { yr } \\
\text { Sept- } \\
\text { Nov }\end{array}$ & $\begin{array}{l}\text { Dec- } \\
\text { Eeb }\end{array}$ \\
\hline $\begin{array}{l}50-70 \mathrm{~N} \\
30-50 \mathrm{~N} \\
10-30 \mathrm{~N} \\
105-10 \mathrm{~N} \\
10-315 \\
30-505 \\
50-705 \\
10-905\end{array}$ & $\begin{array}{l}0 \\
0 \\
0 \\
0 \\
0 \\
0 \\
0 \\
0 \\
0\end{array}$ & $\begin{array}{l}0 \\
0 \\
0 \\
0 \\
0 \\
0 \\
0 \\
0 \\
0\end{array}$ & $\begin{array}{l}0 \\
0 \\
0 \\
0 \\
0 \\
0 \\
0 \\
0 \\
0\end{array}$ & $\begin{array}{l}0 \\
0 \\
0 \\
0 \\
0 \\
0 \\
0 \\
0 \\
0\end{array}$ & $\begin{array}{l}0 \\
0 \\
0 \\
0 \\
0 \\
0 \\
0 \\
0 \\
0\end{array}$ & $\begin{array}{l}0 \\
0 \\
0 \\
0 \\
0 \\
.07 \\
.18 \\
.05 \\
.01\end{array}$ & $\begin{array}{l}0 \\
0 \\
0 \\
0 \\
0 \\
.24 \\
.70 \\
.26 \\
.01\end{array}$ & $\begin{array}{l}.01 \\
.08 \\
.28 \\
.11 \\
.01 \\
.15 \\
.33 \\
.42 \\
.05\end{array}$ & $\begin{array}{r}.03 \\
.61 \\
1.65 \\
.56 \\
.04 \\
.13 \\
.23 \\
.22 \\
.01\end{array}$ & $\begin{array}{r}.09 \\
.84 \\
.65 \\
.29 \\
.05 \\
.04 \\
1.77 \\
.47 \\
.04\end{array}$ & $\begin{array}{r}.03 \\
.40 \\
.43 \\
.21 \\
.08 \\
.1 .19 \\
3.48 \\
1.29 \\
.04\end{array}$ & $\begin{array}{r}.05 \\
.74 \\
2.81 \\
1.01 \\
.11 \\
.37 \\
.82 \\
1.05 \\
.12\end{array}$ & $\begin{array}{l}.07 \\
2.03 \\
5.52 \\
1.88 \\
.12 \\
.10 \\
.33 \\
.31 \\
.02\end{array}$ & $\begin{array}{r}.19 \\
1.66 \\
1.30 \\
.59 \\
.09 \\
.40 \\
1.12 \\
.29 \\
.03\end{array}$ & $\begin{array}{r}.03 \\
.49 \\
.53 \\
.31 \\
.10 \\
.25 \\
2.19 \\
.81 \\
.03\end{array}$ & $\begin{array}{r}.04 \\
.44 \\
1.77 \\
.64 \\
.07 \\
.23 \\
.51 \\
.67 \\
.07\end{array}$ & $\begin{array}{l}.04 \\
1.28 \\
3.47 \\
1.10 \\
.08 \\
.12 \\
.21 \\
.20 \\
.01\end{array}$ & $\begin{array}{r}.12 \\
1.05 \\
.82 \\
.37 \\
.06 \\
.25 \\
.71 \\
.10 \\
.01\end{array}$ & $\begin{array}{r}.01 \\
.31 \\
.33 \\
.19 \\
.06 \\
.47 \\
1.39 \\
.51 \\
.01\end{array}$ & $\begin{array}{l}.02 \\
.29 \\
1.12 \\
.40 \\
.04 \\
.15 \\
.33 \\
.42 \\
.05\end{array}$ & $\begin{array}{r}.03 \\
.91 \\
2.19 \\
.74 \\
.05 \\
.08 \\
.13 \\
.13 \\
.01\end{array}$ & $\begin{array}{l}.08 \\
.67 \\
.52 \\
.23 \\
.04 \\
.16 \\
.45 \\
.12 \\
.01\end{array}$ & $\begin{array}{r}.21 \\
.12 \\
.04 \\
.30 \\
.87 \\
.33 \\
.01\end{array}$ & $\begin{array}{l}.02 \\
.19 \\
.70 \\
.25 \\
.03 \\
.09 \\
.21 \\
.27 \\
.03\end{array}$ \\
\hline
\end{tabular}

Tablo A-7b. Fractional deposition (x 100) for Injoction of debris during Sep-Feb into the High Polar Atmosphere (above $50 \mathrm{~km}$ ).

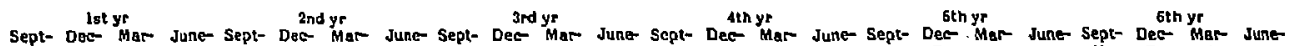
Latitude Nov Feb May Aug Nov Feb May Aug Nov Feb, May Aug Nov Feb May Aug Nov Feb May Aug Nov Feb May Aug

\begin{tabular}{|c|c|c|c|c|c|c|c|c|c|c|c|c|c|c|c|c|c|c|c|c|c|c|c|c|}
\hline $\begin{array}{l}70-90 N \\
50-70 N \\
30-50 N \\
10-30 N \\
105-10 N \\
10-305 \\
30-50 S \\
50-905 \\
70-905\end{array}$ & $\begin{array}{l}0 \\
0 \\
0 \\
0 \\
0 \\
0 \\
0 \\
0 \\
0\end{array}$ & $\begin{array}{l}0 \\
0 \\
0 \\
0 \\
0 \\
0 \\
0 \\
0 \\
0\end{array}$ & $\begin{array}{l}0 \\
0 \\
0 \\
0 \\
0 \\
0 \\
0 \\
0 \\
0\end{array}$ & $\begin{array}{l}0 \\
0 \\
0 \\
0 \\
0 \\
0 \\
0 \\
0 \\
0\end{array}$ & $\begin{array}{l}n \\
0 \\
0 \\
0 \\
0 \\
0 \\
0 \\
0 \\
0\end{array}$ & $\begin{array}{l}.01 \\
.09 \\
.36 \\
.13 \\
0 \\
0 \\
0 \\
0 \\
0\end{array}$ & $\begin{array}{l}.01 \\
.52 \\
1.40 \\
.48 \\
0 \\
0 \\
0 \\
0 \\
0\end{array}$ & $\begin{array}{l}.09 \\
.84 \\
.65 \\
.20 \\
.01 \\
.05 \\
.14 \\
.04 \\
.01\end{array}$ & $\begin{array}{l}.03 \\
.44 \\
.47 \\
.27 \\
.04 \\
.28 \\
.83 \\
.31 \\
.01\end{array}$ & $\begin{array}{r}.06 \\
.93 \\
. .54 \\
1.28 \\
.05 \\
.15 \\
.33 \\
.42 \\
.05\end{array}$ & $\begin{array}{l}.08 \\
2.57 \\
6.96 \\
2.37 \\
.08 \\
.12 \\
.21 \\
.20 \\
.01\end{array}$ & $\begin{array}{r}.24 \\
2.10 \\
1.64 \\
.73 \\
.11 \\
.51 \\
1.41 \\
.37 \\
.02\end{array}$ & $\begin{array}{r}.04 \\
.63 \\
.67 \\
.39 \\
.12 \\
.94 \\
. .77 \\
1.02 \\
.03\end{array}$ & $\begin{array}{r}.04 \\
.59 \\
2.23 \\
.80 \\
.09 \\
.29 \\
.65 \\
.83 \\
.09\end{array}$ & $\begin{array}{l}.03 \\
. .62 \\
4.38 \\
1.49 \\
.10 \\
.15 \\
.27 \\
.25 \\
.01\end{array}$ & $\begin{array}{l}.15 \\
1.33 \\
1.02 \\
.47 \\
.07 \\
.32 \\
.89 \\
.23 \\
.02\end{array}$ & $\begin{array}{r}.03 \\
.40 \\
.43 \\
.24 \\
.08 \\
.59 \\
1.74 \\
.64 \\
.02\end{array}$ & $\begin{array}{r}.03 \\
.37 \\
1.41 \\
.51 \\
.06 \\
.19 \\
.41 \\
.53 \\
.08\end{array}$ & $\begin{array}{l}.03 \\
1.02 \\
2.77 \\
.94 \\
.06 \\
.09 \\
.17 \\
.15 \\
.01\end{array}$ & $\begin{array}{l}.09 \\
.04 \\
.65 \\
.29 \\
.04 \\
.20 \\
.58 \\
.15 \\
.01\end{array}$ & $\begin{array}{l}.01 \\
.25 \\
.27 \\
.16 \\
.05 \\
.37 \\
1.10 \\
.41 \\
.01\end{array}$ & $\begin{array}{l}.01 \\
.24 \\
.89 \\
.32 \\
.04 \\
.11 \\
.26 \\
.33 \\
.04\end{array}$ & $\begin{array}{l}.01 \\
.65 \\
1.74 \\
.60 \\
.04 \\
.08 \\
.11 \\
.10 \\
.01\end{array}$ & $\begin{array}{l}.05 \\
.53 \\
.41 \\
.19 \\
.03 \\
.13 \\
.35 \\
.09 \\
.01\end{array}$ \\
\hline
\end{tabular}


As noted in Peterson (1970), to extend the deposition tables beyond the tabulated values, multiply the last seasonal entries by the following factors to obtain values 1 year later:

\section{Table Factor}

$\begin{array}{ll}2 a-d & 0.35 \\ 3 a-d & 0.71 \\ 4 a-b & 0.63 \\ 5 a-d & 0.19 \\ 6 r-d & 0.63 \\ 7 a-b & 0.63\end{array}$




\section{APPENDIX B (GLODEP2 USERS GUIDE)}

A CRAY-1 controllee, GLODEP2, is a CIVIC compilation and load of the LRLTRAN souce file glodep2e. The FORTLlB and TV8OCRAY libraries are used in the loader.

The controllee is executed by typing

glodep2 / time value

and then the user will be asked if input is from file or tty. If from tty, the code operates in a conversational mode asking for input when required.

If the user speeifies that the input is from a file, then the code asks for the disk file name. The input file may be ereated using the TRIX routines and is described below.

If file input, then the deck is made up of lines:

nloc rough

format $(12,15.2)$

nloc-ne of specific locations for dose, $\leq 5$

rough is roughness factor ( $=0.7$ from Glasstone)

hl latl raini h2 lat2 rain2 h3 lat3 rain3 h4 lat4 rain4 h5 lat5 rain5

format $(5(1 \times, 81$, f 5. 2, f8.2) $)$

hi=n or $s$ for Northern or Southern Hemisphere, $i=1,2, \ldots$, nloc

lat $i=$ degrees of latitude, $0 . \leq$ lati $\leq 90$. $i=1,2, \ldots$, nloc

raini=average rainfall, $\mathrm{mm} / \mathrm{yr}, \mathrm{i}=1,2$,.., nloc

ngstart nqexp tropst lplf lpld lenf land jwl 
format (i6, lx, i6,el 0.2,5(lx,i1))

ngstart is gtr to start dose exposure ( $g \geq 0)$

ngexp is $\mathrm{nr}$ of gtrs for dose exposure (.g $\geq 0$ )

tropst is fraction of quarter for troposphere deposition

lplf $=1$ if plot latitude deposition fractions, $=0$ otherwise

lpld $=1$ if plot latitude doses, $=0$ otherwise

Ienf $=1$ if plot deposition fraction cantours, $=0$ otherwise

lend $=1$ if plot dose contours, $=0$ otherwise

$j w l=1$ if -1.2 weepons decey law

jwl=2 if 1 -Mton decay curve from Chester \& Chester

$y \operatorname{minf}$ ymaxf

format (2(1x,e9. 2))

this eard is read only if lplf $=1$

If you wish to scale the plot, input ymin and ymax

If you wish to plot to be self-sealed, input both values as zero

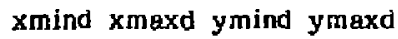

format $(4(1 x, \mathrm{e} 9,2))$

this card is read only if lpld=1

If you wish to scale the plat, input $x \min , \mathrm{xmax}, \mathrm{ymin}$ and $y$ max

If you wish the plot to be self-scaled, input all values as zero

nqtri nentrf rqtrpp

format (3i5)

this card is read only if lenf $=1$

nqtrf is the number of quarters for each contour plot

nentrf is the number of contours to plot ( $\leq 25)$

ngtrppf is the number of quarters for each frame of plot 
ngtrd nentrd ngtrppd

format (3i5)

this card is read only if lend=1

ngtrd is the number of yuarters for each contour plot

nentrd is the number of contours to plot ( $\leq 25)$

ngtrppd is the number of querters for each frame of plot

nqs iyears

format $(\mathrm{i} 1,1 \mathrm{x}, \mathrm{i4})$

ngs is the start quarter for first injeetion

$$
\begin{aligned}
& =1 \text { for Dee-Feb } \\
& =2 \text { for Mar-May } \\
& =3 \text { for Jun-Aug } \\
& =4 \text { for Sep-Nov }
\end{aligned}
$$

iyears is the calendar year to start injeetion, e.g. 1985 or 2000

ntest ty fi hob nf nnf detl

format $(a 4,3(1 x, e 9.2), 3(1 x, 19),(1 x, e 9.2))$

ntest is a key word indicator, this card repeats for the eurrent injection guarter until ntest=endq

The next injection quarter is started and repeated, ace. until ntest=endi, end of injections, then a computation is done.

ntest is then read to determine if to end the run or to return for a new set of injections

ntest=equt if this injection is equatorial

=polr if this injection is polar

=endg if completed this quarters injections 
$=$ endi if completed all injections

=next if to go back for new start quarter and year

rends if run is to be terminated

(note: there must be at least one card with ntest=equt or polar followed Ly either ntest $=e n d q$ or endi, then by ntest=endr)

ty=yield in Mtons for weafon

$\mathfrak{f f}=\mathrm{fission}$ fraction for weapon

hob=height of burst for weapon

twhFtotal number of weepons for this burst

nf $=0$ if only weapons on this iurst

$=1$ if attack on reprocessing plant, 10-yr high level storage

$=2$ if attack on 30-day spent fuel storage

$=3$ if attack on $3600 \mathrm{MW}(\mathrm{th}) \mathrm{LWR}$, (steady state)

$=4$ if attack on 10-yr spent fuel storage at reactor

nf $f=n u m b e r$ of the above nuelear facilities under attack with this burst if $n i=0$

detl=latitude of detonation, $0 \leq$ detl $\leq 90$ (only northern latitudes may be used).

The computation will then proceed. The high-speed printer file will be named hil111111 or if a file by this name exists, a r.ew file name (incremented by 1) will be ereated. The graphics output will be in a standard F3yyyy0x file where yyyy is randomly chosen by the computer operating system.

The following example input desk is the same as ibe U.S.S.R. portion of the exchange used in Section 4.2 
Sample input deck of card images

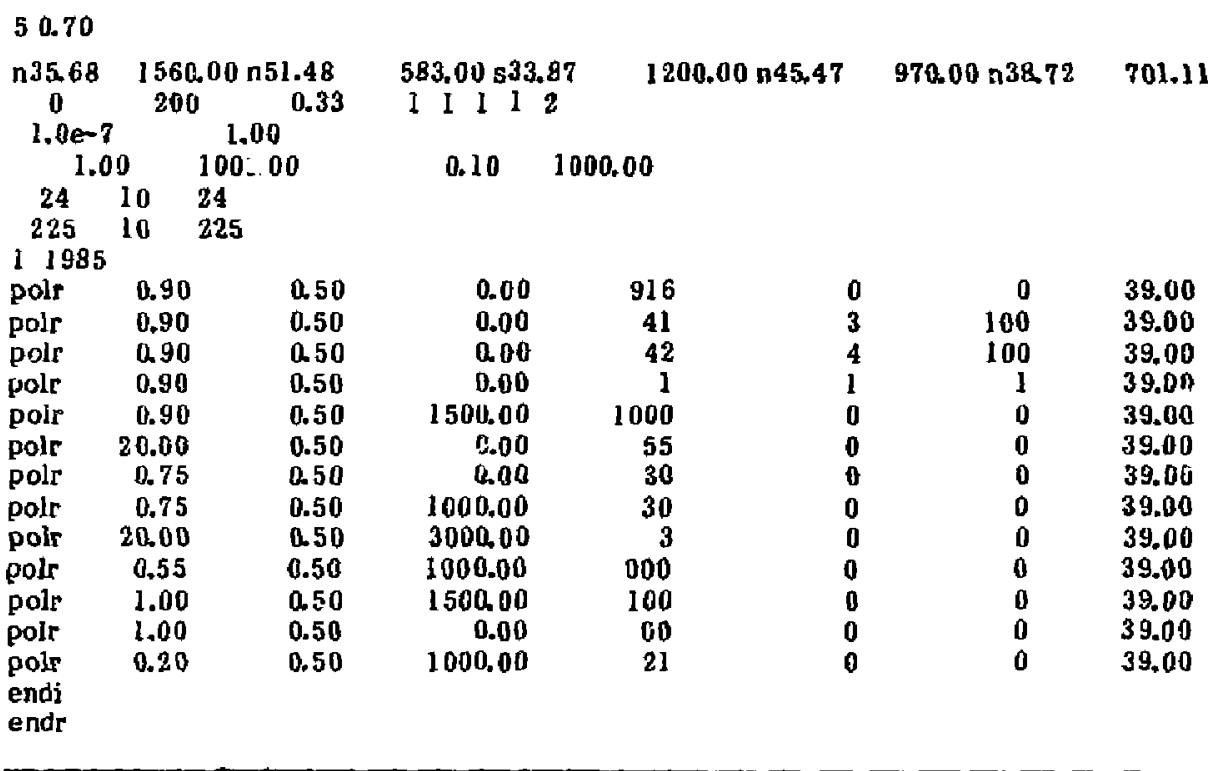

The current GLODEP2 controllee requires 443202 (octal) words. The drop-file reguires 405400 (octal) words, about $14 \%$ of core on the Cray-l computer. The run time of the code is dependent an the number of injections, the number of times a nutelear facility is attacked, and the number of specific locations at which to compute dose.

The sample ealeulation for Sextion 4.2 using an input deck with 9 additional injections to simulate the U.S. attack at 50 degrees latitude required 1.36 minutes of run-time. 